\title{
Annual Radioactive Waste Tank Inspection Program - 1994
}

Westinghouse Savannah River Company

Savannah River Site

Aiken, SC 19808

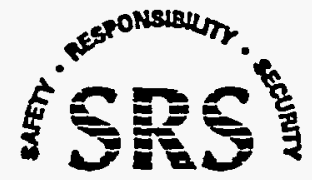

Prepared for the U.S. Department of Energy under Contract No. DE-AC09-89SR18035 


\section{Disclaimer}

This report was prepared as an account of work sponsored by an agency of the United States Government. Neither the United States Government nor any agency thereof, nor any of their employees, makes any warranty, express or implied, or assumes any legal liability or responsibility for the accuracy, completeness, or usefulness of any information, apparatus, product, or process disclosed, or represents that its use would not infringe privately owned rights. Reference herein to any specific commercial product, process, or service by trade name, trademark, manufacturer, or otherwise does not necessarily constitute or imply its endorsement, recommendation, or favoring by the United States Government or any agency thereof. The views and opinions of authors expressed herein do not necessarily state or reflect those of the United States Government or any agency thereof.

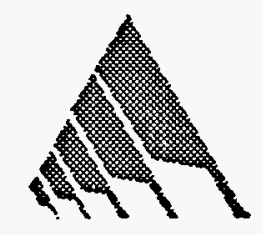

Published in cooperation with WSRC Management Services Department Publications Group. 
WSRC-TR-95-166

Publication Date: April 1995

\section{Annual Radioactive Waste Tank Inspection Program - 1994(U)}

F. G. McNath, Sr.

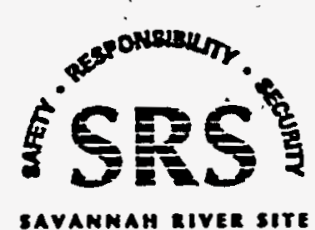

Prepared for the U.S. Department of Energy under Contract No. DE-AC09-89SR1 8035 
This page intentionally left blank.

, 


\section{DISCLAIMER}

Portions of this document may be illegible in electronic image products. Images are produced from the best available original document. 


\section{Contents}

Introduction

Summary

Inspection Program

Background 5

Tank Description 5

Inspection Methods ................................................................... 10

Program Implementation .................................................... 13

Visual Imagery............................................................................ 13

Ultrasonic Testing................................................................... 13

1994 Inspection Results ...................................................... 13

Summary of Inspection Results .......................................... 14

Appendix A-Waste Tanks at SRS ..................................... 21

Appendix B-Summary of 1994 Inspections....................... 23

\section{List of Figures}

1. Type I Waste Storage Tank .............................................. 6

2. Type II Waste Storage Tank ............................................... 7

3. Type IV Waste Storage Tank .............................................. 8

4. Type III Waste Storage Tank ............................................... 9 
This page intentionally left blank. 


\section{Introduction}

Aqueous radioactive wastes from Savannah River Site (SRS) separations processes are contained in large underground carbon steel tanks. Inspections made during 1994 to evaluate these vessels and evaluations based on data accrued by inspections made since the tanks were constructed are the subject of this report. 
This page intentionally left blank. 


\section{Summary}

The 1994 inspection program revealed the condition of the Savannah River Site waste tanks had not changed significantly from that reported in the previous annual report, except for waste tanks 19 and 22. In Tank 19, two sites were identified where water had leaked through the steel liner wall. In Tank 22, water had leaked through the concrete roof. Otherwise, no evidence of structural degradation or loss of waste confinement was observed in 1994 for these or any other waste tanks.

In 1994 a total of 4568 photographs were made and 93 visual and video inspections were performed. 
This page intentionally left blank. 


\section{Inspection Program}

\section{Background}

Alkaline aqueous radioactive wastes produced at the Savannah River Site are received and managed in large underground tanks. The waste comes primarily from nuclear fuel reprocessing operations in the separations areas ( $\mathrm{F}$ and $\mathrm{H}$ ) and contains most of the radioactive fission products from SRS operations. The waste stored in the tanks is present in three phases: sludge, supernate, and salt formed by supernate evaporation and cooling. The supernate and salt phases consist primarily of $\mathrm{NaNO}_{3}$ and $\mathrm{NaNO}_{2}$. The fission product content is 5 to 20 curies per gallon for the supemate and 10 to 60 curies per gallon for the salt. The sludge consists primarily of $\mathrm{MnO}_{2}$ and $\mathrm{Fe}(\mathrm{OH})_{2}$ with a fission product content up to 500 curies per gallon.

Waste tank leak detection capabilities are essential to meet the primary objective of the SRS radioactive waste management program: to manage the waste in such a manner as to minimize the radiation exposure and associated risk to man and his environment over the lifetime of the radionuclides.

The detection of leaked waste is based on two principles: disappearance of material from its proper location and appearance of material in an improper location. At SRS, primary reliance is on the latter because the quantity of the waste detectable in an improper location is much less than that detectable by inventory change in a large tank. Capacity of SRS tanks is 0.75 to 1.3 million gallons. Although rigorous tank inventory surveillance is practiced, primary leak detection methods rely on automatic surveillance of those areas into which the leaked waste is most likely to migrate.

The annulus of each double-wall tank is equipped with at least two single-point conductivity probes for leak detection. These probes are located at the bottom of the annulus and on opposite sides of the tank. The single-wall tanks are built on slabs with a network of leak collection channels that drain to a common sump. Continuous sump level monitoring and frequent sump liquid sampling provide the leak detection. Besides the automatic surveillance, routine direct visual surveys are made in the annular spaces and nonroutine direct visual surveys are made in primary tanks through opened access risers and/or inspection ports in the roof.
In 1961-62, following leakage of waste into the annuli of Tanks $9,10,14$, and 16 , the first remote imaging inspections were made of some tanks using a periscope. Random inspections continued through 1970. A program was initiated in November 1971 to periodically inspect all waste tanks using remote visual imagery techniques to monitor for corrosion and other degradation, waste leakage, anomalies of any type, and to investigate process or equipment concerns.

Steel thickness measurements have been made periodically of waste tanks using ultrasonic techniques to monitor for general corrosion. An analog-type instrument was used in 1967 and 1969 to measure the thickness of the primary wall of selected double-wall tanks. In 1972, a more precise instrument was put in service. About 24,000 measurements made over a period of 14 years (1972 through 1985) indicated that no thinning of SRS tanks has occurred. The only tank at SRS that has experienced detectable corrosion is Tank 23, a tank with a unique service history. The upper wall interior surfaces show general corrosion with mild pitting. The pitting is broad but shallow. This tank is used to receive contaminated water from 244-H, the Receiving Basin for Off-Site Fuels, and 245-H, the Resin Regeneration Facility. Steel thickness measurements were resumed in 1994 using a newly-designed ultrasonic testing (UT) system.

Inspections are complicated by factors such as radiation and contamination, remote operation as far as $\mathbf{4 0}$ feet below grade, and insertion of equipment through small (generally 5 to 8-inch-diameter) access openings. Inspection techniques to circumvent these difficulties have been developed; they yield quality visual images and thickness measurements. The techniques include periscopic systems, direct photographic systems, closed circuit television systems, and systems to measure waste tank wall and bottom plate thicknesses.

Waste tank inspection hás been important in leak detection. The leaksites in nine of the eleven cracked tanks have been identified by direct visual inspection or by one of the remote inspection techniques. Since the inspection program was initiated in 1971, six tanks were found to have leaksites that were not recognized before the program was implemented. In the double-wall tanks, annulus conductivity probes were not activated by these leaks because of the small amount of leakage. The leaked waste evaporated to 
dryness, sealing the cracks before any leaked waste reached a conductivity probe. However, remote inspections detected the dry deposits of leaked waste on the wall of these tanks.

The waste tanks in-service inspection program is comprised of visual imagery inspections and ultrasonic steel thickness measurements. This report gives results of the 1994 inspection program and summarizes significant findings of previous in-service inspections for each waste tank.

\section{Tank Description}

SRS has subsurface storage tanks of four different designs. All of the tanks are constructed of carbon steel and reinforced concrete. They serve as containment vessels for storage and processing of radioactive wastes. Appendix A lists tank location, design type, project number, and construction period. A brief description of the different tank designs is given in the following paragraphs.

\section{Type I Tanks}

The 12 original storage tanks constructed between 1951 and 1953 are designated Type I tanks. Tanks 1 through 8 are in F Area and Tanks 9 through 12 are in H Area. Each primary tank has a capacity of 750,000 gallons, is 75 feet in diameter and $241 / 2$ feet high. Figure 1 shows the essential features of Type I tanks, including the primary tank, the secondary pan, and the concrete support structure.
The primary container is a closed cylindrical tank with flat top and bottom constructed from 1/2-inch-thick' steel plates. The top and bottom are joined to the cylindrical sidewall by curved knuckle plates. The primary tank is set within a circular pan of 1/2-inch-thick steel plates. The annulus pan is 5 feet deep and 5 feet larger in diameter than the primary tank, thus forming an annular space $21 / 2$ feet wide. The tank and pan are set on a 30-inch-thick base slab and are enclosed by a cylindrical 22 -inch-thick reinforced concrete wall and a flat concrete roof, also 22 inches thick. There are twelve 2-foot-diameter concrete columns within the primary tank to support the roof. Each column has a flared capital and is encased in 1/2-inchthick steel plate.

A 9-foot layer of earth was placed over the tanks for radiation shielding. Cooling for each type I tank is provided by 36 parallel (water pipe) cooling coils.

A dehumidification duct in the annulus of each tank is routed from the tank top to the bottom of the annulus where it encircles the tank. The duct has distribution outlets and its cross-sectional area decreases as the distance from the air supply increases. Access to the tank interior is provided -at eight locations, and to the annular space at four locations, through riser pipes. Each of the 12 riser pipes is capped at the top with a concrete plug. Each plug is provided with two 5-inch-diameter ports equipped with removable plugs. Some of these ports provide access for inspections.

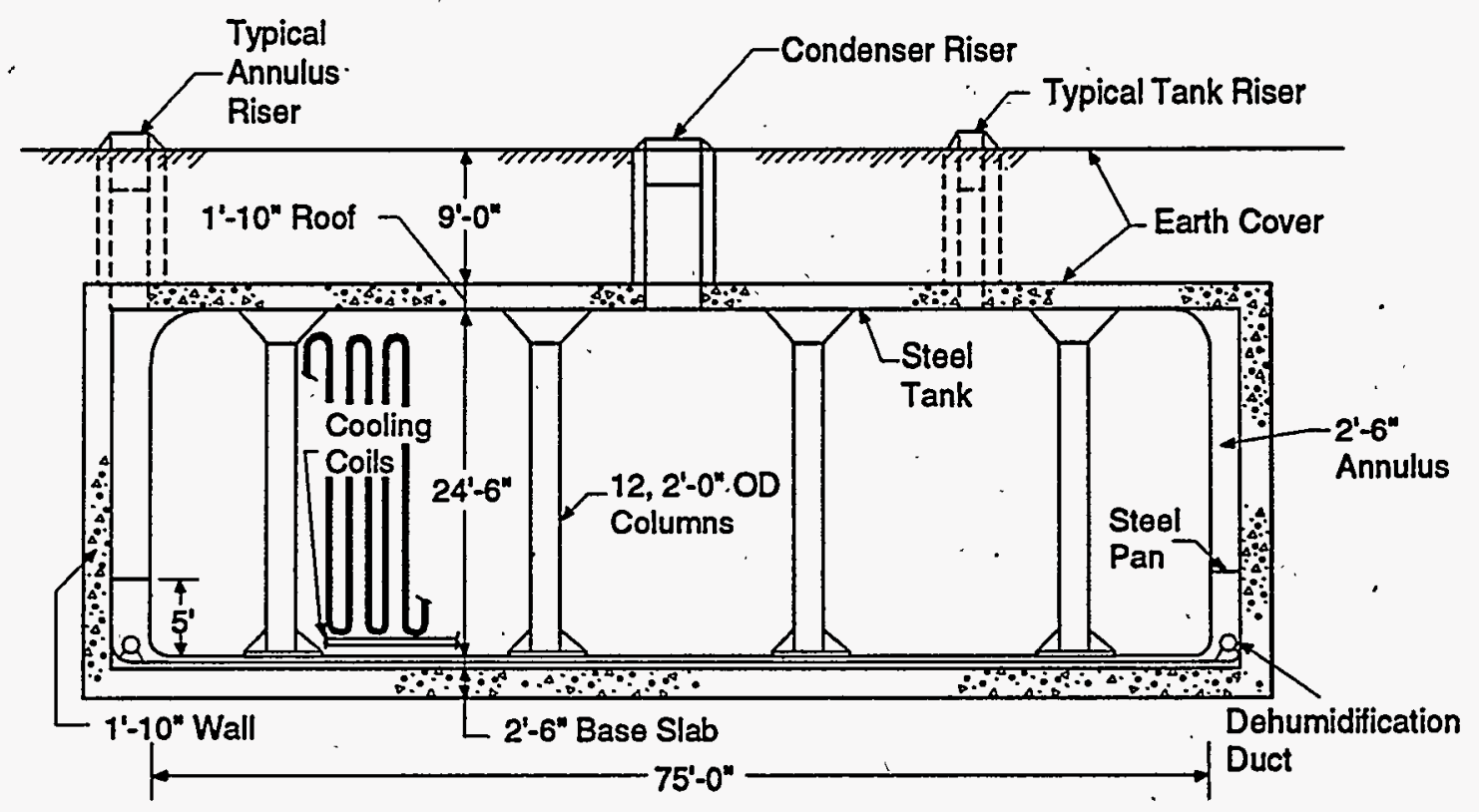

Figure 1. Cooled Waste Storage Tank, Type I (Original 750,000 Gallons). 


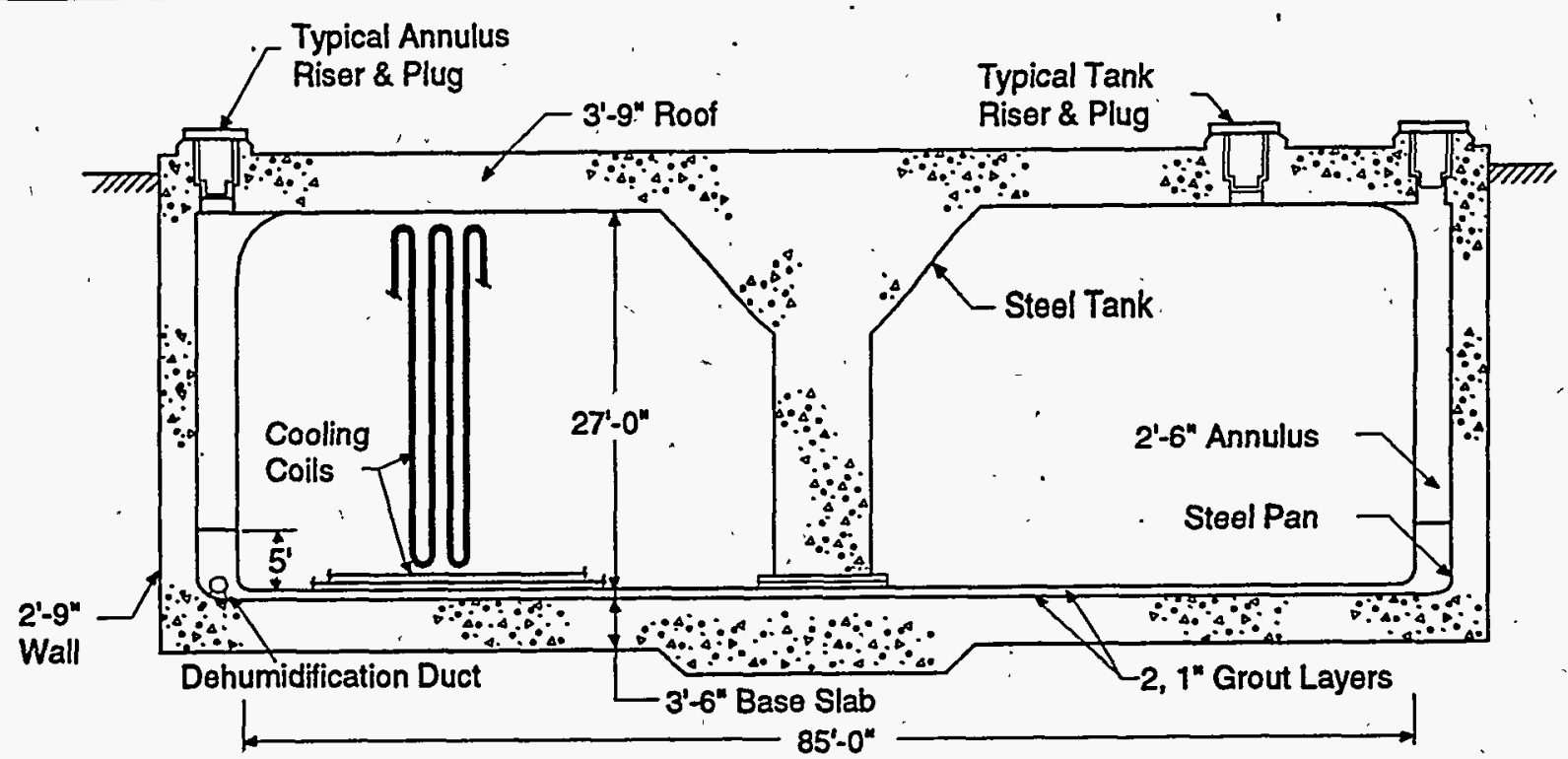

Figure 2. Cooled Waste Storage Tank, Type II (Original 1,030,000 Gallons).

All welds in the pan and primary tank were radiographically inspected, defects were corrected, and the welds were rechecked radiographically. The welds in the flat bottoms of both the pan and the tank were vacuum-tested for leaks. Additionally, both vessels were hydrostatically tested. The water was maintained at full height in the tank for 24 hours before inspection for leaks was made. Cooling water piping was hydrostatically tested at $300 \mathrm{psig}$ and then leak-tested with 100 psig air pressure in the piping.

\section{Type II Tanks}

Tanks 13 through 16, constructed in $H$ Area in 1955 and 1956, are designated Type II tanks. Figure 2 is a cross section of this type. Each primary tank has a capacity of $1,030,000$ gallons and is 85 feet in diameter and 27 feet high.

The primary container for Type II tanks consists of two concentric steel cylinders assembled with a flat bottom and a flat top into a form somewhat like a doughnut. The top and bottom are joined to the outer cylinder by rings of curved knuckle plates. The inner cylinder is flared at the top to accommodate the roof support column. This cylinder is joined to the flat steel top with a continuous butt weld and to a base fastened to the bottom with a continuous T-weld. Steel thicknesses are:

\begin{tabular}{lc}
\multicolumn{1}{c}{ Plate } & Thickness, inch \\
\hline Top and bottom & $1 / 2$ \\
Upper knuckle & $9 / 16$ \\
Wall & $5 / 8$ \\
Lower knuckle & $7 / 8$
\end{tabular}

The primary tank is set on a 1-inch sand bed within a circular pan of 1/2-inch thick steel plate, 5 feet deep and 5 feet larger in diameter than the primary tank, thus forming an annular space $21 / 2$ feet wide. The tank and pan assembly is surrounded by a cylindrical reinforced concrete enclosure with a 33-inch-thick wall and a flat concrete roof that is 45 inches thick: The tank and pan assembly and the surrounding wall are set on a foundation slab that is 42 inches thick. The roof is supported by both the wall and a central concrete column that fits within the inner cylinder of the vessel. The 45-inch-thick concrete roof provides radiation shielding; therefore, no earth overburden is required. Cooling for each Type II tank is provided by 44 parallel (water pipe) cooling coils. Access to the tank interior is provided at eight locations, and to the annular space at four locations, through riser pipes. Each of the 12 riser pipes is capped at the top with a concrete plug. Each plug is provided with two 5-inch-diameter ports equipped with removable plugs. The ports provide access for inspection. In addition to the four annulus risers, other access openings (10 to 14 additional openings per tank) have been drilled into the annulus of each of these tanks to permit inspection of seventy-three to ninety-six percent of the exterior walls of the primary vessels.

A dehumidification duct in the annulus of each tank is routed from the tank top to the bottom of the annulus where it encircles the tank. The duct has distribution outlets and its cross-sectional area decreases as the distance from the air supply increases.

All welds in the primary tanks were radiographically inspected, defects were corrected, and the welds were 
rechecked radiographically. However, the annulus pans were not inspected radiographically. The welds in the flat bottoms of these pans and the primary tanks were vacuumtested for leaks, and the primary and secondary vessels were hydrostatically tested. Cooling water piping was hydrostatically tested at 300 psig and then leak-tested, with $100 \mathrm{psig}$ air pressure in the piping.

\section{Type IV Tanks}

Tanks 17 through 24 are single-wall uncooled tanks. These tanks were designed for storage of waste that does not require auxiliary cooling. Tanks 17 through 20 were constructed in F Area in 1958 and Tanks 21 through 24 were constructed in H Area between 1959 and 1961. Each tank has a capacity of $1,300,000$ gallons and is 85 feet in diameter and 34 feet high (Figure 3 ).

Each Type IV tank is basically a steel-lined, prestressedconcrete tank in the form of a vertical cylinder with a domed roof. Carbon steel plates, 3/8 inch thick, were used to form the cylindrical sides and flat bottom portion of the steel liners. The knuckle plates at the junction of the bottom and the sidewall are 7/16 inch thick. Concrete was built up around the steel vessel by the "shotcrete" technique.

Radiation shielding of the Type IV tanks in F Area was accomplished by applying at least 32 inches of earth over each of the 7-inch-thick concrete domes. H-Area tanks were shielded similarly, except that the earth cover was at least 44 inches thick to accommodate a somewhat higher radiation level from the waste.

Access to the interior of the tank is provided at six locations through riser pipes. Each riser pipe is capped at the top with a concrete plug. Some of these risers provide access for inspection.

All welds in the steel liners were radiographically inspected. All of the welded tank-bottom seams and the upper seams of the knuckle rings were vacuum leaktested. Prior to the back-filling operation, each tank was hydrostatically tested by filling with water to the normal fill line. The tank was allowed to remain filled until it was to be placed in use for waste storage.

\section{Type III Tanks}

The most recently constructed tanks are designated as Type III tanks (Figure 4). Twenty-seven tanks were built between 1967 and 1981. Tanks 25 through 28, 33 and 34, and 44 through 47 are located in F Area. Tanks 29 through 32, 35 through 43 and 48 through 51 are located in H Area.

The Type III tank design was developed after an investigation into the causes of the leaks from the primary vessel of the Type I and Type II tanks. The study concluded that the leak-producing mechanism was nitrate-induced stress-corrosion cracking at sites in or near the weld seams, and that stress relieving after fabrication should eliminate the cracking. For The type III tanks, means were provided for

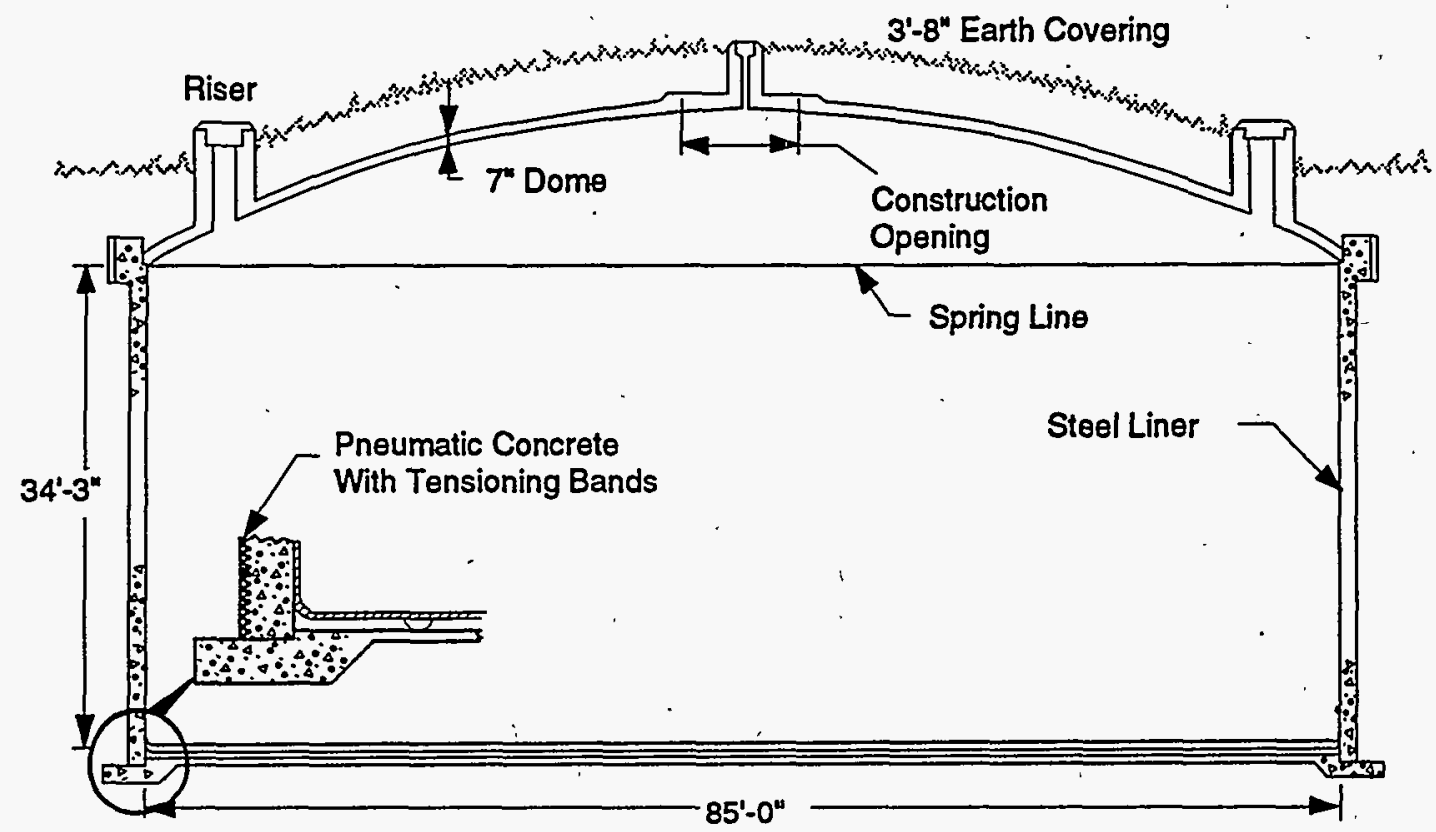

Figure 3. Uncooled Waste Storage Tank, Type IV (Prestressed Concrete Walls, 1,300,000 Gallons). 


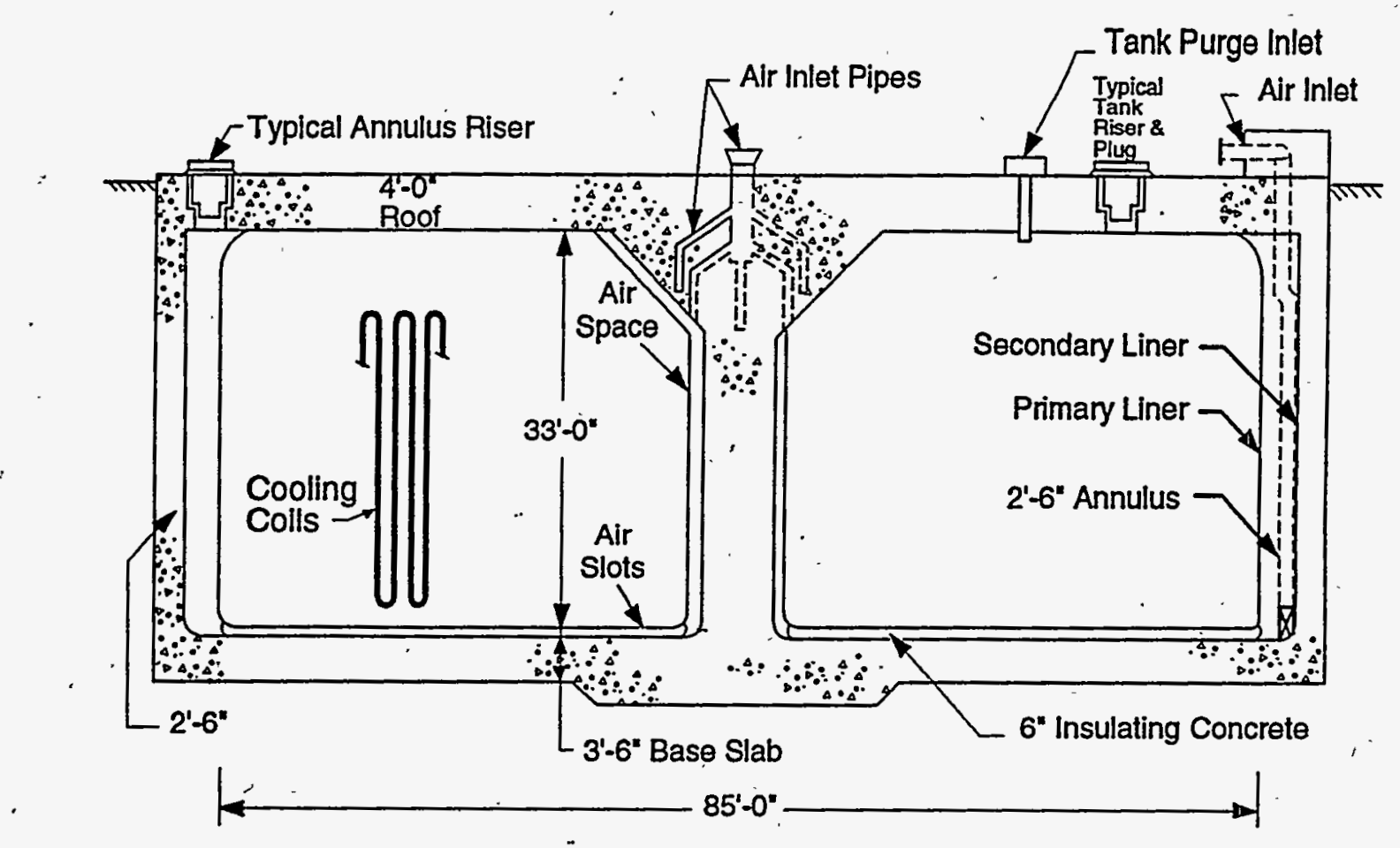

Figure 4. Cooled Waste Storage Tank, Type III (Stress Relieved Primary Liner, 1,300,000 Gallons).

heating each finished tank to relieve the stresses generated during fabrication. In addition, some stress patterns were avoided, or minimized, by mounting the roof supporting column on the foundation pad rather than on the bottom of the primary tank (as in Types I and II), and by providing an annular clearance around the roof supporting column. Each primary tank holds 1,300,000 gallons and is 85 feet in diameter and 33 feet high.

Type III tanks are similar to the doughnut-like design of Type II tanks. Each primary vessel is made of two concentric cylinders joined to washer-shaped top and bottom plates by curved knuckle plates. Steel thicknesses are:

\begin{tabular}{lc} 
Plate & Thickness, inch \\
\hline Top and bottom & $1 / 2$ \\
Upper knuckle & $1 / 2$ \\
Outer wall & \\
Upper band & $1 / 2$ \\
Middle band & $5 / 8$ \\
Lower band & $3 / 4$ \\
Inner wall & \\
Upper band & $1 / 2$ \\
Lower band & $5 / 8$ \\
Lower knuckle & \\
Outer $\quad$ (tanks $25-28$ and 33 - 51) & $7 / 8$ \\
& (tanks 29 through 32) \\
Inner & 1 \\
&
\end{tabular}

The primary tank is set on a 6-inch bed of insulating concrete within the secondary containment vessel. The concrete bed is grooved radially so that ventilating air can flow from the inner to the outer annulus. If any waste were to leak from the tank bottom or center annulus wall, liquid would move through the grooves, facilitating detection in the outer annulus.

The secondary vessel is 5 feet larger in diameter than the tank, thus providing an outer annulus $21 / 2$ feet wide. The secondary vessel is made of 3/8-inch-thick steel throughout. Its sidewalls rise to the full height of the primary tank. The nested two-vessel assembly is surrounded by a cylindrical reinforced concrete enclosure with a 30-inch-thick wall. The enclosure has a 48 -inch-thick flat reinforced concrete roof which is supported by the concrete wall and a central column that fits within the inner cylinder of the vessel. The 48-inch-thick concrete provides radiation shielding; hence, no earth overburden is required.

Cooling for the Type III tanks is provided by either deployable (water pipe) cooling coil bundles installed through risers in the tank top or 23 parallel (water pipe) cooling coils distributed throughout the tank.

A dehumidification duct in the annulus of each tank is routed from the tank top to the bottom of the annuius where it encircles the tank. The duct has distribution out- 
lets and its cross-sectional area decreases as distance from the air supply increases. In these tanks, additional airflow is directed through the inner annulus, passing beneath the primary tank through radial grooves in the concrete base slab and is exhausted into the outer annulus.

Tanks 29 through 34 were placed in service prior to 1976. These tanks were constructed with annulus riser pipes at four locations, providing inspection access through 5inch-diameter ports. All other Type III tanks were placed in service after 1976 and have annulus riser pipes at 18 locations that are 8-inches in diameter. These ports are equidistant around the tank and provide for inspection of all of the exterior wall of the primary vessel. In 1982, fourteen to sixteen additional 8-inch diameter ports per tank were drilled in the tops of Tanks 29 through 34 to provide adequate access ports for inspection of all of the exterior wall of their primary vessels. All Type III tanks have interior riser pipes at various locations which provide inspection access through ports with diameters ranging from 5 to 8 inches. All inspection access ports are equipped with removable plugs.

All butt welds on the primary tanks. were radiographically inspected, except welds on the horizontal roof surface. On the secondary vessels of Tanks 29 through 34, all butt welds joining bottom plates, knuckle plates, and the lowest courses of center-column and outer-wall plates, were radiographically inspected. On all other Type III tanks, all plate welds in the secondary tanks were radiographically inspected. All defects were corrected and the welds were rechecked radiographically.

The Quality Assurance Program included inspection of all radiographs by two independent groups of certified weld inspectors, and all radiographs were permanently stored for future reference. All spots on the inside or outside of the primary tanks and the inside of the secondary tanks, where clips or lugs were removed and where other excisions were made, were examined by magnetic particle or liquid penetrant techniques, and any defects were repaired.

All butt welds on the secondary tanks were vacuum leaktested. All welds in the bottom assemblies of the primary tanks, including knuckle rings and lowest course welds, were vacuum leak-tested before each bottom assembly. was lowered into final position, and then tested a second time after the stress-relieving operation. A full hydrostatic test, the filling of each primary tank to a depth of $32 \mathrm{ft}$ and allowing it to stand 48 hours, was conducted after stress relieving. No leaks were found by the hydrostatic tests. All circumferential welds in the pipe loops of the deployable cooling coil bundles below the 1/2-inch-thick plate at the base of the riser plug were radiographed. The assembled cooler piping was tested hydrostatically to $500 \mathrm{psig}$ and halide leak tested at 300 psig. Welds in the distributed cooling coils were radiographed and similarly leak tested.

The primary tank was stress-relieved in place after all high temperature work (other than roof attachments) had been completed. Full stress relief, at $1100^{\circ} \mathrm{F}$, was accomplished in accordance with the general requirements of the ASME Boiler and Pressure Vessel code.

\section{Inspection Methods}

Techniques have been developed for remote examination and evaluation of the waste tanks and ancillary equipment. For visual imaging, direct photography systems developed at SRS were the primary method used. Optical periscopes, boroscopes, and closed circuit television systems were also used where direct photography was not possible or where these systems provided a more comprehensive examination. Only the direct photography systems will be described since the other systems were used less frequently and are similar to systems used widely in the nuclear industry. Tank wall thickness measurements were made using a crawler developed at SRS that was, interfaced with the P-scan Ultrasonic Inspection System.

Wide-angle direct photography was used for general inspections of double-wall tank annuli and the primary vessels of both double-wall tanks and single-wall tanks. This technique uses a $35 \mathrm{~mm}$ Zeiss-Ikon Hologon Ultrawide camera that surveys a large area in a single photograph. The lens is a $15 \mathrm{~mm}$ f/8 fixed aperture and fixed focus with a field of focus from 18 inches to infinity. The lens is distortion free with a 100-degree field of view. A bank of four electronic flash units are synchronized with the camera to provide illumination. The camera is not shielded since residence time in a tank is minimal.

Another direct photography technique was used for detailed inspections. The camera is shielded to reduce the degrading effect of ionizing radiation on the photographic film. The camera's residence time in a waste tank for this technique is longer than the wide-angle direct photographic technique (i.e., a few minutes versus a few seconds); hence; shielding is required. The camera used is the $35 \mathrm{~mm}$ Leitz's Leica CL. It is a rangefinder camera with interchangeáble lenses. Normally a $21 \mathrm{~mm}$ lens is used for tank inspection. Alternate lenses are available with focal lengths of $28 \mathrm{~mm}$ and $35 \mathrm{~mm}$. Illumination is provided by a single electronic fiash unit. 
The P-scan Ultrasonic Inspection System was interfaced with a SRS-developed, tank-wall crawler to perform examination of the Type III waste tanks. The crawler design permits access to tank walls via 8-inch-diameter access ports. P-scan is a highly developed ultrasonic tech-: nique for corrosion mapping and weld inspection. Acquired data are stored on disks for evaluation. The system provides documentation of $100 \%$ of the measured area and color imaging of inspection results. Adjustable color levels can be used to display percentage of area examined within specific thickness ranges. The system calculates the minimum, maximum, and mean value for each scan. 
This page intentionally left blank. 


\section{Program Implementation}

\section{Visual Imagery}

The 1994 inspection program used three visual imagery techniques: photography, closed circuit television, and periscopic inspection. The primary inspection methods were direct photography techniques, e.g., making a series of photographs providing detailed views of the tank and wide-angle photography for obtaining overviews of large areas. Closed circuit television systems and periscopes were generally used to further investigate conditions found during scheduled inspections and to troubleshoot process problems in tanks and ancillaries.

The inspection program objective to continuously evaluate the waste tanks was satisfied in 1994 by photographic documentation. The policy developed for photographic inspections in 1972 specified biennial inspection in the annuli of all waste tanks and annual inspection of those tanks in which waste had breached the primary vessel. Biennial inspections do not include all annulus risers. Therefore, the time required to inspect a tank through all annulus risers could be as long as four years. However, the wide-angle direct photography method developed in 1974 was used to make annual inspections through all risers where inspections were not made by other photographic methods. Hence, inspections were made through all accessible annulus risers of the double-wall tanks, and at least one inspection was made in the interior of each single-wall tank.

For Tanks 1 through 12 , inspections are limited to no more than $25 \%$ of the exterior of the primary vessel wall and the annular space due to limited annulus access. This is considered adequate since the tanks are inactive, i.e., waste is not routinely transferred to or from them. These tanks are continuously monitored for leakage by instrumentation installed in their annuli. Additionally, for those tanks that have known leaksites in the primary vessel, the supernate phase has been removed, minimized, or the level lowered below the level of known leaksites.

\section{Ultrasonic Testing}

A new ultrasonic testing system wàs put in service late in 1994. The system interfaces the P-scan Ultrasonic Testing System with a remotely controlled crawler developed at SRS. Ultrasonic thickness mapping was performed on vertical strips of the walls of two tanks. The strips mapped were 0.5 foot wide and about 32 feet high (near tank top to the tank bottom knuckle). These were baseline measurements for this newly implemented facet of the inspection program.

\section{Inspection Results}

The 1994 inspection program was successfully completed. The annuli of all double-wall tanks and the interiors of single-wall tanks were inspected at accessible risers by at least one photographic technique. Other inspections were made as required by operating conditions and equipment performance. Details and results of all inspections made in 1994 are listed in Appendix B.

The inspections performed in 1994 revealed that the condition of the waste tanks was virtually unchanged from the condition observed in 1993 except for Tanks 19 and 22, two of the eight Type IV Tanks at SRS. Inleakage was observed in both of these tanks.

Inspections in Tank 19 revealed two sites in the 3/8-inchthick steel liner where inleakage had occurred. The leaksites are 317 inches and 330 inches high on the wall. Waste was removed from this tank in 1981. Since then, the tank has contained ballast water that normally does not exceed a height of 80 inches. The leaksites were observed from inside the tank. It is not possible to perform visual inspection of the outside of the steel liner, as it is formed against the concrete wall which encases the tank.

Water was observed dripping into Tank 22 from the concrete roof. Deposits were observed on the underside of the roof at the site of water inleakage. Additional inspection and study of this condition was carried forward into 1995, and results were not available for this report.

Inspections were continued in the concrete encasement for the out-of-service transfer lines to Tanks 1 through 8 . In 1993, a 12-inch-thick concrete cover located about 20 feet below grade was found to be cracked and slumped down into the encasement a few inches. Inspection photographs taken in January, February, May, and November of 1994 to monitor the cracked cover for movement indicated that the cover had not moved.

Rainwater continued to leak into the annuli of most tanks. Water inleakage was evidenced mostly by surface stains; occasionally by calcite deposit (Tank 26); and changed configuration of leaked waste in the annulus (Tank 9) (see 
Appendix B). The leakage.was primarily due to poor seals at riser gaskets and failed seals where process pipes penetrate tank annuli below gradie.

Ultrasonic thickness measurements were performed on the wall of Tanks 48 and 50 to obtain P-scan baseline data. The data did not reveal any service-induced corrosion (i.e., general thinning or pitting).

\section{Summary of Inspection Results}

The following is a brief description of tank conditions as revealed by inspections and examinations made through 1994.

\section{Tank 1}

Tank 1 was placed in service in 1954. A small amount of dry waste was observed on the annulus floor in 1969. Subsequent inspections have revealed no additional leakage. Inspection of the exterior wall of the primary vessel is limited to 25\% using existing inspection techniques through the four risers that provide access to the annulus. Examination of the observable portion of the tank wall has not revealed the location of the leak(s). Inspection photographs of the steel surface of the tank and the annulus have shown no significant surface corrosion or other anomalies. Ultrasonic measurements made in 1978, 1979, 1981, 1983 , and 1985 showed no detectable thinning of the tank wall had occurred.

\section{Tank 2}

Tank 2 was placed in service in 1955: Examinations of the observable portion (25\%) of the exterior of the primary vessel wall and the annulus have shown no leakage, significant surface corrosion, or other anomalies. Ultrasonic measurements made in $1967,1972,1973,1977,1981$, and 1985 showed no detectable thinning of the tank wall.

\section{Tank 3}

Tank 3 was placed in service in 1956. Examinations of the observable portion (25\%) of the exterior of the primary vessel wall and the annulus have shown no.leakage, significant surface corrosion, or other anomalies. Ultrasonic measurements made in 1973, 1977, 1981, and 1985 showed no detectable thinning of the tank wall.

\section{Tank 4}

Tank 4 was placed in service in 1961. Examinations of the observable portion (25\%) of the exterior of the primary vessel wall and the annulus have shown no leakage, significant surface corrosion, or other anomalies. Ultrasonic measurements made in 1973, 1977, 1981, and 1985 showed no detectable thinning of the tank wall.

\section{Tank 5}

Tank 5 was placed in service in 1959. Examinations of the observable portion (25\%) of the exterior of the primary vessel wall and the annulus have shown no leakage, significant surface corrosion, or other anomalies. Ultrasonic measurements made in 1973, 1977, 1981, and 1985 showed no detectable thinning of the tank wall.

\section{Tank 6}

Tank 6 was placed in service in 1964. Examinations of the observable portion (25\%) of the exterior of the primary vessel wall and the annulus have shown no leakage, significant surface corrosion, or other anomalies. Ultrasonic measurements made in $1974,1977,1978,1979,1981$, and 1985 showed no detectable thinning of the tank wall.

\section{Tank 7}

Tank 7 was placed in service in 1954. Examinations of the observable portion (25\%) of the exterior of the primary vessel wall and the annulus have shown no leakage, significant surface corrosion, or other anomalies. Ultrasonic measurements made in 1974, 1979, 1981, 1983, and 1985 showed no detectable thinning of the tank wall.

\section{Tank 8 .}

Tank 8 was placed in service in 1956. Examination's of the observable portion (25\%) of the exterior of the primary vessel wall and the annulus have shown no leakage, significant surface corrosion, or other anomalies. Ultrasonic measurements made in 1973, 1977, 1981, and 1985 showed no detectable thinning of the tank wall.

\section{Tank 9}

Tank 9 was placed in service in 1955. Leakage from the tank primary vessel into the annulus pan may have occurred as early as 1955 when the "necklace" alarm, a conductivity leak detection device, shorted out permanently. Leakage was not certain until liquid waste was observed in the annulus pan in 1957. Currently, the annulus pan contains 8 to 10 inches of dry leaked waste. Examinations of the observable portion (25\%) of the exterior of the primary vessel wall have shown three leaksites high on the tank wall; 269,271 , and 276 inches above the tank bottom. None of these leaksites is the source of the leaked waste in the annulus pan. The waste leaked at these sites was only enough to form localized small nodules. The leak(s) that are the source of the waste in the annulus pan 
have not been observed. Inspections have shown no significant surface corrosion, and the ultrasonic measurements made in 1979 and 1983 showed no detectable thinning of the tank wall.

\section{Tank 10}

Tank 10 was placed in service in 1955 . The first indication that Tank 10 had leaked was in 1959 when dry waste was discovered in the annulus pan during a visual inspection. Currently, the annulus pan contains about 2 inches of dry leaked waste. Examinations of the observable portion (25\%) of the exterior of the primary vessel wall have not shown the source of the leaked waste or. any other leaksite(s). Inspections have shown no significant surface corrosion and the ultrasonic measurements made in 1979 and 1983 showed no detectable thinning of the tank wall.

\section{Tank 11}

Tank 11 was placed in service in 1955. Twenty-five percent of the exterior of the primary vessel wall is observable via the four risers that provide access to the annulus. Inspections performed in 1974 revealed two leaksites. The leaksites are 189 and 235 inches above the tank bottom. Inspections have shown no significant surface corrosion and ultrasonic measurements made in 1973, 1977, 1981, and 1985 showed no detectable thinning of the tank wall.

\section{Tank 12}

Tank 12 was placed in service in 1956. Twenty-five percent of the exterior of the primary vessel wall is observable via the four risers that provide access to the annulus. Inspections in 1974 revealed two leaksites. The leaksites are 93 and 105 inches above the tank bottom. Inspections have shown no significant surface corrosion and ultrasonic measurements made in 1972, 1973, 1977, 1981, 1983, and 1985 showed no detectable thinning of the tank wall.

\section{Tank 13}

Tank 13 was placed in service in 1956. Ninety percent of the exterior of the primary vessel wall is observable via the 13 risers that provide access to the annulus. Inspections in 1977 revealed a leaksite 279 inches above the tank bottom. In 1980, another leaksite was discovered 269 inches above the tank bottom. Inspections have shown no significant surface corrosion and ultrasonic measurements made in 1974, 1979, and 1985 showed no detectable thinning of the tank wall.

\section{Tank 14}

Tank 14 was placed in service in 1957. The first indication that tank 14 had leaked was in 1959 when dry leaked waste was observed in the annulus pan. Currently, the annulus pan contains 12-13 inches of dry leaked waste. Eighty-nine percent of the exterior of the primary vessel wall is observable via the 18 risers that provide access to the annulus. Inspections have located 33 leaksites and it is estimated that there are about $\mathbf{5 0}$ leaksites in this tank. All of the observed leaksites are near the bottom circumferential weld that is 2.5 feet above the tank bottom, except one leaksite that was observed approximately. 24 feet above the tank bottom. Inspections have shown no significant surface corrosion and ultrasonic measurements made in 1979 and 1983 showed no detectable thinning of the tank wall.

\section{Tank 15}

Tank 15 was placed in service in 1960. Inspections in 1972 below one of the four risers providing access to the annulus revealed two leaksites near the bottom circumferential weld about 2.5 feet above the tank bottom. Twelve additional risers were installed increasing the observable portion of the primary vessel wall from $25 \%$ to $96 \%$. Inspections in 1973, via the additional risers, revealed eleven other leaksites. No additional leaksites have been found since 1973. Inspections have shown no significant surface corrosion and ultrasonic measurements made in $1972,1977,1980$, and 1984 showed no detectable thinning of the tank wall.

\section{Tank 16}

Tank 16 was placed in service in 1959. Liquid waste was detected in the annulus pan in 1959. Seventy-three percent of the exterior wall of the primary vessel is observable via the sixteen risers that provide access to the annulus. Inspections in 1961 and 1962, through 13 risers, revealed . about 175 leaksites in the tank wall. In October 1961 and March 1962, two 5 3/4-inch-diameter samples were cut from the top horizontal circumferential weld of the tank wall about 40 feet apart. Metallurgical examination indicated the cause of the cracks was nitrate-induced stress corrosion. Extensive inspection performed since 1972 indicated the primary vessel wall has 300 to 350 leaksites. In $1978,70 \%$ of the leaked waste in the annulus pan was removed leaving an insoluble heel containing approximately 30,000 curies $137 \mathrm{Cs}$. Waste removal from the interior of the primary vessel was completed in 1980. Inspections have shown no significant surface corrosion. No ultrasonic steel thickness measurements of the tank were made because of the number of leaksites and the 
presence of leaked waste deposits on the primary vessel exterior. This tank is presently "out of service."

\section{Tank 17}

Tank 17 was placed in service in 1961. Examinations of the steel liner have shown no evidence of failure, significant surface corrosion, or other anomalies.

\section{Tank 18}

Tank 18 was placed in service in 1959. Examinations of - the steel liner have shown no evidence of failure, significant surface corrosion, or other anomalies. Ultrasonic measurements made in 1977, 1980, and 1983 showed no detectable thinning of the liner bottom.

\section{Tank 19}

Tank 19 was placed in service in 1961 and emptied in 1981. The tank has remained empty except for ballast water. Examinations of the steel liner have revealed two failures, i.e. sites where inleakage had occurred. The failures are in the wall of the steel liner at heights of $\mathbf{3 1 7}$ inches and 330 inches. Inspection records photographically document that these leaksites existed before 1994 . However, inspection made from the interior of this singlewall (visual inspection of the exterior is not possible) had to track changes in artifacts at the sites by periodic inspections to judge that inleakage had occurred.

Ultrasonic measurements made in 1982 and 1985 showed no detectable thinning of the liner bottom.

\section{Tank 20}

Tank 20 was placed in service in 1960 . Examinations of the steel liner have revealed four failure sites. In 1983, leaksites were observed in the wall of the steel liner at heights of 22, 24.5, and 26.5 feet. In 1990, a leaksite was confirmed in the liner wall at a height of 26.25 feet. This site had been suspect since 1984 .

This is a single-wall tank with no annulus. The leaksites in the steel liner were detected by inspections made from the tank interior, since inspection of the exterior was not possible. Artifacts observed on the interior wall indicated that water had leaked through the steel liner into the tank. It is possible that a small quantity of waste may have leaked from the steel liner. However, groundwater monitoring has given no indication that waste escaped the encasement.

\section{Tank 21}

Tank 21 was placed in service in 1961. Examinations of the steel liner have shown no evidence of failure, significant surface corrosion, or other anomalies. Ultrasonic measurements made in 1973,1977, 1980, and 1983 showed no detectable thinning of the liner bottom.

\section{Tank 22}

Tank 22 was placed in service in 1965. Examinations of the steel liner have shown no evidence of failure, significant surface corrosion, or other anomalies. Water was discovered leaking through the concrete roof in 1994. Ultrasonic measurements made in 1974, 1977, 1980, and 1983 showed no detectable thinning of the liner bottom.

\section{Tank 23}

Tank 23 was placed in service in 1964. Examinations of the steel liner have revealed corrosion but no evidence of failure. Ultrasonic measurements made in 1973, 197?, 1980, and 1983 showed no detectable thinning of the liner bottom. Examinations of the steel liner have shown rust and tubercles on the surface of the upper portion. This tank serves as a receiver tank for inhibited contaminated water from buildings $244-\mathrm{H}$, the Receiving Basin for Off-Site Fuels, and 245-H, the Resin Regeneration Facility. The tank was filled to less than $50 \%$ capacity to maintain the remaining space for emergency use. This mode of operation exposed only the lower half of the tank to the inhibited contents, and exposed the upper half of the tank to a warm humid atmosphere. In 1984, rust and tubercles were cleaned from two small areas, exposing the steel surface. The cleaned liner surface was generally corroded with mild pitting. The pits were broad and shallow.

\section{Tank 24}

Tank 24 was placed in service in 1963. Examinations of the steel liner have shown no evidence of failure, significant surface corrosion, or other anomalies. Ultrasonic measurements made in 1984 showed no detectable thinning of the liner.

\section{Tank 25}

Tank 25 was placed in service in 1980. Examinations of $100 \%$ of the exterior of the primary vessel wall and the annulus have shown no leakage, significant surface corrosion, or other anomalies. Ultrasonic thickness measurements made in 1979 and 1983 showed no detectable thinning of the tank wall. 


\section{Tank 26}

Tank 26 was placed in service in 1980. Examinations of $100 \%$ of the exterior of the primary vessel wall and the annulus have shown no leakage, significant surface corrosion, or other anomalies. Ultrasonic thickness measurements made in 1979 and 1983 showed no detectable thinning of the tank wall.

\section{Tank 27}

Tank 27 was placed in service in 1980. Examinations of $100 \%$ of the exterior of the primary vessel wall and the annulus have shown no leakage, significant surface corrosion, or other anomalies. Ultrasonic thickness measurements made in 1979 and 1983 showed no detectable thinning of the tank wall.

\section{Tank 28}

Tank 28 was placed in service in 1980 . Examinations of $100 \%$ of the exterior of the primary vessel wall and the annulus have shown no leakage, significant surface corrosion, or other anomalies. Ultrasonic thickness measurements made in 1979 and 1983 showed no detectable thinning of the tank wall.

\section{Tank 29}

Tank 29 was placed in service in 1971. Examinations of $100 \%$ of the exterior of the primary vessel wall and the annulus have shown no leakage, significant surface corrosion, or other anomalies. Ultrasonic thickness measurements made in 1973 and 1974 showed no detectable thinning of the tank wall.

\section{Tank 30}

Tank 30 was placed in service in 1974. Examinations of $100 \%$ of the exterior of the primary vessel wall and the annulus have shown no leakage, significant surface corrosion, or other anomalies. Ultrasonic thickness measurements made in 1975 showed no detectable thinning of the tank wall.

\section{Tank 31}

Tank 31 was placed in service in 1972. Examinations of $100 \%$ of the exterior of the primary vessel wall and the annulus have shown no leakage, significant surface corrosion, or other anomalies.

\section{Tank 32}

Tank 32 was placed in service in 1971. Examinations of $100 \%$ of the exterior of the primary vessel wall and the annulus have shown no leakage, significant surface corrosion, or other anomalies.

\section{Tank 33}

Tank 33 was placed in service in 1969. Examinations of $100 \%$ of the exterior of the primary vessel wall and the annulus have shown no leakage, significant surface corrosion, or other anomalies.

\section{Tank 34}

Tank 34 was placed in service in 1972. Examinations of $100 \%$ of the exterior of the primary vessel wall and the annulus have shown no leakage, significant surface corrosion, or other anomalies.

\section{Tank 35}

Tank 35 was placed in service in 1977. Examinations of $100 \%$ of the exterior of the primary vessel wall and the annulus have shown no leakage, significant surface corrosion, or other anomalies. Ultrasonic thickness measurements made in 1977, 1981, and 1985 showed no detectable thinning of the tank wall.

\section{Tank 36}

Tank 36 was placed in service in 1977. Examinations of $100 \%$ of the exterior of the primary vessel wall and the annulus have shown no leakage, significant surface corrosion, or other anomalies. Ultrasonic thickness measurements made in 1977, 1981, and 1985 showed no detectable thinning of the tank wall.

\section{Tank 37}

Tank 37 was placed in service in 1978. Examinations of $100 \%$ of the exterior of the primary vessel wall and the annulus have shown no leakage, significant surface corrosion, or other_anomalies. Uttrasonic thickness measurements made in 1977, 1981, and 1985 showed no detectable thinning of the tank wall.

\section{Tank 38}

Tank 38 was placed in service in 1981. Examinations of $100 \%$ of the exterior of the primary vessel wall and the annulus have shown no leakage, significant surface corrosion, or other anomalies. Ultrasonic thickness measurements made in 1980, 198i, and 1984 showed no detectable thinning of the tank wall. 


\section{Tank 39}

Tank 39 was placed in service in 1982. Examinations of $100 \%$ of the exterior of the primary vessel wall and the annulus have shown no leakage, significant surface corrosion, or other anomalies. Ultrasonic thickness measurements made in 1980, 1981, 1984, and 1985 showed no detectable thinning of the tank wall.

\section{Tank 40}

Tank 40 was placed in service in 1986. Examinations of $100 \%$ of the exterior of the primary vessel wall and the , annulus have shown no.leakage, significant surface corrosion, or other anomalies. Ultrasonic thickness measurements made in 1980,1981, and 1984, before putting the tank in service, showed no change in the wall thickness.

\section{Tank 41}

Tank 41 was placed in service in 1982. Examinations of $100 \%$ of the exterior of the primary vessel wall and the annulus have shown no leakage, significant surface corrosion, or other anomalies. Ultrasonic thickness measurements made in 1980, 1981, and 1984 showed no detectable thinning of the tank wall.

\section{Tank 42}

Tank 42 was placed in service in 1982. Examinations of $100 \%$ of the exterior of the primary vessel wall and the annulus have shown no leakage, significant surface corrosion, or other anomalies. Ultrasonic thickness measurements made in 1980,1981, 1984, 1985, and 1990 showed no detectable thinning of the tank wall.

\section{Tank 43}

Tank 43 was placed in service in 1982. Examinations of $100 \%$ of the exterior of the primary vessel wall and the annulus have shown no leakage, significant surface corrosion, or other anomalies. Ultrasonic thickness measurements made in 1980,1981, 1984, and 1985 showed no detectable thinning of the tank wall.

\section{Tank 44}

Tank 44 was placed in service in 1982. Examinations of $100 \%$ of the exterior of the primary vessel wall and the annulus have shown no leakage, significant surface corrosion, or other anomalies. Ultrasonic thickness measurements made in 1980, 1981, and 1984 showed no detectable thinning of the tank wall.

\section{Tank 45}

Tank 45 was placed in service in 1982. Examinations of $100 \%$ of the exterior of the primary vessel wall and the annulus have shown no leakage, significant surface corrosion, or other anomalies. Ultrasonic thickness measurements made in 1980,1981, and 1984 showed no detectable thinning of the tank wall.

\section{Tank 46}

Tank 46 was placed in service as an emergency spare tank in 1980. It was placed in waste storage service in 1994 when it began receiving concentrate from the $2 \mathrm{~F}$ evaporator. Examinations of $100 \%$ of the exterior of the primary. vessel wall and the annulus have shown no significant surface corrosion or other anomalies. Ultrasonic thickness measurements made in 1980,1981, and 1984 showed no detectable thinning of the tank wall.

\section{Tank 47}

Tank 47 was placed in service in 1980. Examinations of $100 \%$ of the exterior of the primary vessel wall and the annulus have shown no leakage, significant surface corrosion, or other anomalies. Ultrasonic thickness measurements made in 1980, 1981, and 1984. showed no detectable thinning of the tank wall.

\section{Tank 48}

Tank 48 was placed in service in 1983. Examinations of $100 \%$ of the exterior of the primary vessel wall and the annulus have shown no leakage, significant surface corrosion, or other anomalies. Ultrasonic thickness measurements made in 1982 and 1994 showed no service induced corrosion.

\section{Tank 49}

Tank 49 was placed in service in 1983. Examinations of $100 \%$ of the exterior of the primary vessel wall and the annulus have shown no leakage, significant surface corrosion, or other anomalies. Ultrasonic thickness measurements made in 1982, prior to placing the tank in service, provide reference measurements for the future.

\section{Tank 50}

Tank 50 was placed in service in 1983. Examinations of $100 \%$ of the exterior of the primary vessel wall and the annulus have shown no leakage, significant surface corrosion, or other anomalies. Ultrasonic thickness measurements made in 1982 and 1994 showed no service-induced corrosion. 


\section{Tank 51}

Tank 51 was placed in service in 1986. Examinations of $100 \%$ of the exterior of the primary vessel wall and the annulus have shown no leakage, significant surface corrosion, or other anomalies. UItrasonic thickness measurements made in 1982, prior to placing the tank in service, provide reference measurements for the future. 
.

This page intentionally left blank. 


\section{Appendix A-Waste Tanks at SRS}

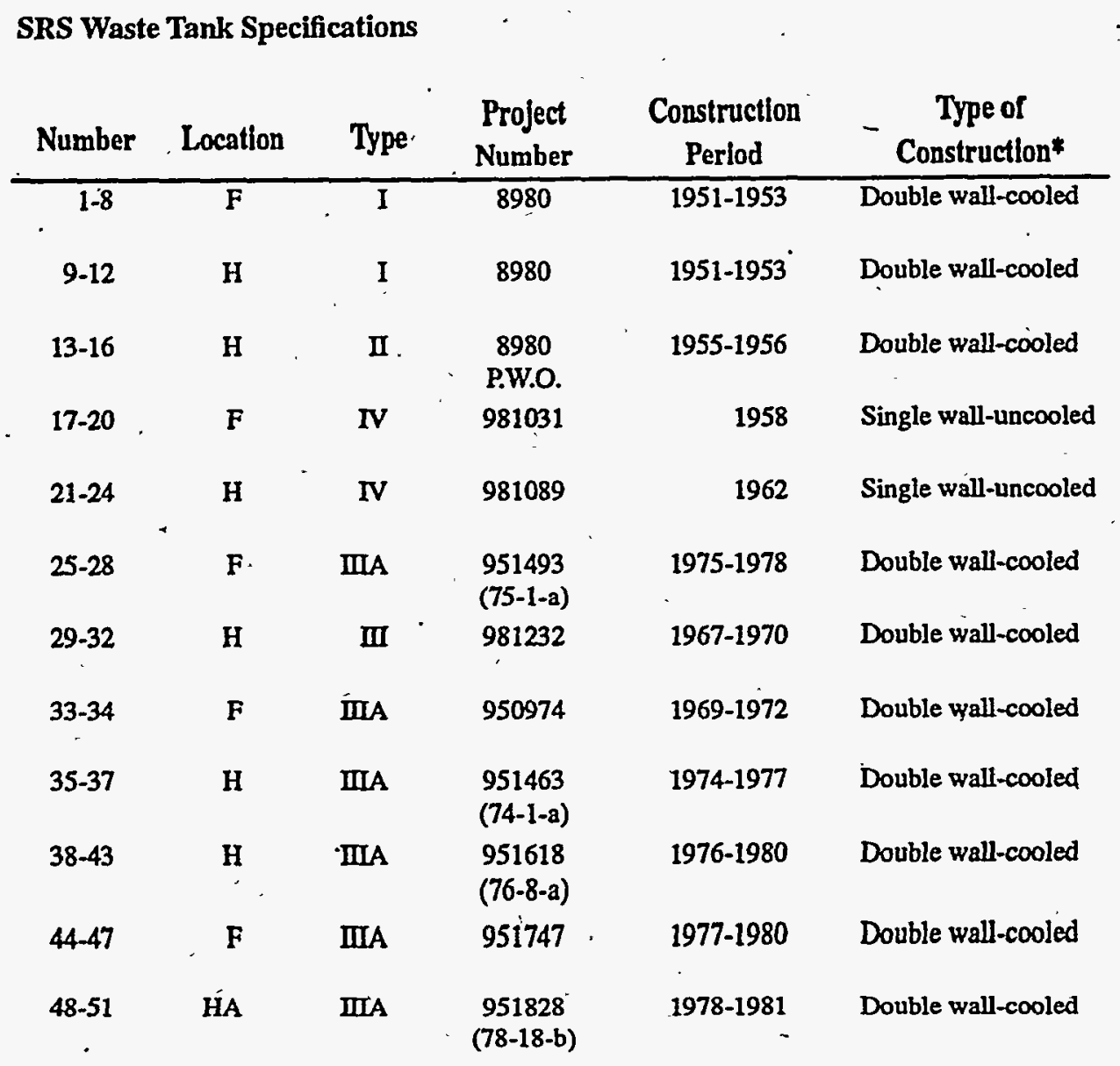

* Tanks 32 and 35 have removable, roof-supported cooling coils. Tanks 30, 33, and 34 have bottom-supported deployable cooling coils. Tanks 29 and 31 have some deployable and some close-packed cooling assemblies, all bottom supported. All other cooled tanks have permanently installed cooling coils, roof-supported in Type I and II and bottomsupported in Type III tanks. 
This page intentionally left blank. 


\section{Appendix B-Summary of 1994 Inspections}

\begin{tabular}{|c|c|c|c|c|c|c|c|c|}
\hline \multirow{2}{*}{ Area } & \multirow{2}{*}{$\begin{array}{c}\begin{array}{c}\text { Tank } \\
\text { or } \\
\text { Ancillary }\end{array} \\
\end{array}$} & \multirow{2}{*}{$\begin{array}{l}\text { Inspec- } \\
\text { tion } \\
\text { Port } \\
\text { East }\end{array}$} & \multirow{2}{*}{$\begin{array}{l}\text { Annulus } \\
\text { or } \\
\text { Interior }\end{array}$} & & \multicolumn{3}{|c|}{$\begin{array}{l}\text { Type of Inspection and } \\
\text { Identification Numbers }\end{array}$} & \multirow[b]{2}{*}{$\begin{array}{ll}\text { Remarks } \\
\end{array}$} \\
\hline & & & & & WAP & DP & PSP & \\
\hline $\bar{F}$ & 01 & East & $A$ & $\cdot$ & & 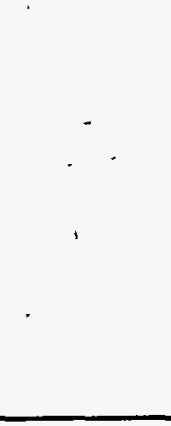 & i. & $\begin{array}{l}\text { CCTV inspection revealed } \\
\text { the conductivity. probe } \\
\text { was properly deployed be- } \\
\text { tween the ventilation } \\
\text { duct and the tank wall. } \\
\text { The magnetically mounted } \\
\text { thermocouple was properly } \\
\text { positioned on the tank } \\
\text { wall. The inspection was } \\
\text { documented on File Tape } \\
\# 297 \text {. }\end{array}$ \\
\hline & & North & A & $05 / 19 / 94$ & . & $7587: 01-17$ & & $\begin{array}{l}\text { Tank condition had not } \\
\text { changed. }\end{array}$ \\
\hline & & South & A & 05/17/94 & & $\begin{array}{c}7586: 09-17 \\
.\end{array}$ & - & $\begin{array}{l}\text { Tank condition had not } \\
\text { changed. Stains observed } \\
\text { on the ventilation duct } \\
\text { were caused by water } \\
\text { which had leaked into the } \\
\text { annulus. }\end{array}$ \\
\hline & & Mest & A & $09 / 19 / 94$ & & - & & $\begin{array}{l}\text { CCTV inspection revealed } \\
\text { the conductivity probe } \\
\text { was properly deployed be- } \\
\text { tween the ventilation } \\
\text { duct and the tank wall. } \\
\text { The inspection was docu- } \\
\text { mented on file Tape \#297. }\end{array}$ \\
\hline $\mathbf{F}$ & 02 & $\begin{array}{c}\text { East } \\
\text {. }\end{array}$ & $\mathbf{A}$ & $03 / 11 / 94$ & $7494: 03$ & -1 & & $\begin{array}{l}\text { Tank condition was nor- } \\
\text { mal. Stains and marks } \\
\text { observed on the ventila- } \\
\text { tion duct were caused by } \\
\text { water that leaked into } \\
\text { the annulus. The mag- } \\
\text { netically mounted thermo- } \\
\text { couple was properly posi- } \\
\text { tioned on the tank wall. }\end{array}$ \\
\hline & & North & A & $05 / 13 / 94$ & & $7578: 01-16$ & & $\begin{array}{l}\text { Tank condition was nor- } \\
\text { mal. }\end{array}$ \\
\hline & & Horth & A & $06 / 22 / 94$ & 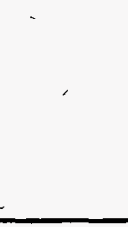 & & & $\begin{array}{l}\text { CCTV inspection revealed } \\
\text { the conductivity probe } \\
\text { was properly deployed be- } \\
\text { tween the ventilation } \\
\text { duct and the secondary } \\
\text { tank wall. }\end{array}$ \\
\hline
\end{tabular}

The numbers listed under WAP, OP, and PSP identify photographs in the HLVE files.

WAP $=$ wide angle photography; $D P=$ direct photography; PSP = periscopic photography;

CTS = concentrate transfer system; OB = diversion box; EVAP = evaporator; $G D \mathrm{~L}$ = gravity drain line; PP = pump pit; RHLWE = replacement high level waste evaporator; SS = storm sewer; WLE = waste line encasement. 


$\begin{gathered}\text { Tank Inspec: Annulus } \\ \text { or } \\ \text { tion } \\ \text { or }\end{gathered}$
$\frac{\text { Area Ancillary }}{02} \frac{\text { Port }}{\text { South }} \frac{\text { Interior }}{\text { A }} \frac{\text { Date }}{03 / 11 / 94}$

\begin{tabular}{lllllll} 
& & Hest & A & $03 / 111 / 94$ & $7494: 01$ & \\
\hline F & 03 & East & A & $03 / 11 / 94$ & $7495: 02$ \\
\cline { 3 - 6 } & & Horth & A & $03 / 11 / 94$ & $7495: 01$
\end{tabular}

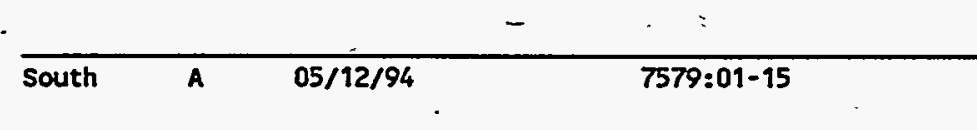

\begin{tabular}{llll}
\hline West $\quad$ A & $03 / 11 / 94$ & $7495: 03$
\end{tabular}

$\begin{array}{llllll}\text { F } & 04 & \text { East } & \text { A } & 03 / 11 / 94 & 7496: 02\end{array}$

\section{Remarks}

Tank condition was normal. The conductivity probe was deployed on the annulus floor between the veritilation duct and the tank wall.

Tank condition was normal.

Tank condition was normal.

Tank condition was normal. Visual inspection revealed the conductivity probe was 'properly deployed on the annulus floor between the ventilation duct and the tank wall.

Tank condition was normal. Visual inspection revealed the conductivity probe was properly deployed on the annulus floor. between the ventilation duct and the tank wall.

Tank condition was normal. Stains and marks observed on the ventilation duct were caused by water which had leaked into the annulus. The magnetically mounted thermocouple was properly positioned on the tank wall.

Tank condition was normal. Stains and marks observed on the ventilation duct were caused by water which had leaked into the annulus. The magnetically mounted thermocouple was properly positioned on the tank wall. 


$\begin{gathered}\text { Tank, Inspec- Annulus } \\ \text { or } \\ \text { tion or }\end{gathered}$
$\begin{gathered}\text { Area Ancillary } \\ \text { F }\end{gathered} \frac{\text { Port }}{\text { Horth }} \frac{\text { Interior }}{\text { A }} \frac{\text { Date }}{03 / 11 / 94}$

Remarks

Tank condition was normal. Stains observed on the tank wall were caused by water which had leaked into the annulus. Visual inspection revealed the conductivity probe was properly deployed on the annulus floor between the ventilation duct and the tank wall.

\begin{tabular}{llll}
\hline South & A & $05 / 13 / 94$ & $7580: 01-17$ \\
\hline South & A & $06 / 22 / 94$ &
\end{tabular}
Tank condition was normal. CCTV inspection revealed the conductivity probe was deployed on the annulus floor between the ventilation duct and the secondary vessel wall.

\begin{tabular}{llll}
\hline Hest & A & $03 / 11 / 94$ & $7496: 01$
\end{tabular}
Tank condition was normal. Stains and marks observed on the annulus floor were caused by water which had leaked into the annulus.

\begin{tabular}{|c|c|c|c|c|c|c|}
\hline \multirow[t]{4}{*}{$F$} & 05 & East & A & $03 / 11 / 94$ & $7497: 02$ & $\begin{array}{l}\text { Tank condition was nor- } \\
\text { mal. }\end{array}$ \\
\hline & & East & A & $03 / 11 / 94$ & 7497:03, & $\begin{array}{l}\text { Tank condition was nor- } \\
\text { mal. }\end{array}$ \\
\hline & & Horth & A & $03 / 11 / 94$ & $7497: 04$ & $\begin{array}{l}\text { Tank condition was nor- } \\
\text { mal. The conductivity } \\
\text { probe was deployed on } \\
\text { the annulus floor between } \\
\text { the ventilation duct and } \\
\text { the secondary vessel } \\
\text { wall. }\end{array}$ \\
\hline & & South & A & $03 / 11 / 94$ & $7497: 01$ & $\begin{array}{l}\text { Tank condition was nor- } \\
\text { mal. CCTV inspection re- } \\
\text { vealed the conductivity } \\
\text { probe was properly de- } \\
\text { ployed on the annulus } \\
\text { floor between the venti- } \\
\text { lation duct and the tank } \\
\text { wall. }\end{array}$ \\
\hline
\end{tabular}




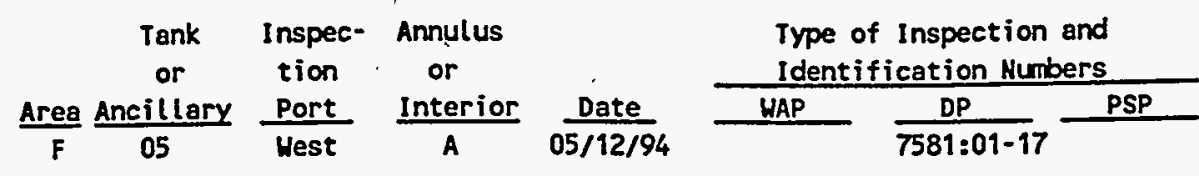

- Remarks

Tank condition was normal. Stains and marks observed on the tank wall were caused by water that leaked into the annulus. The magnetically mounted thermocouple was properly positioned on the tank wall.

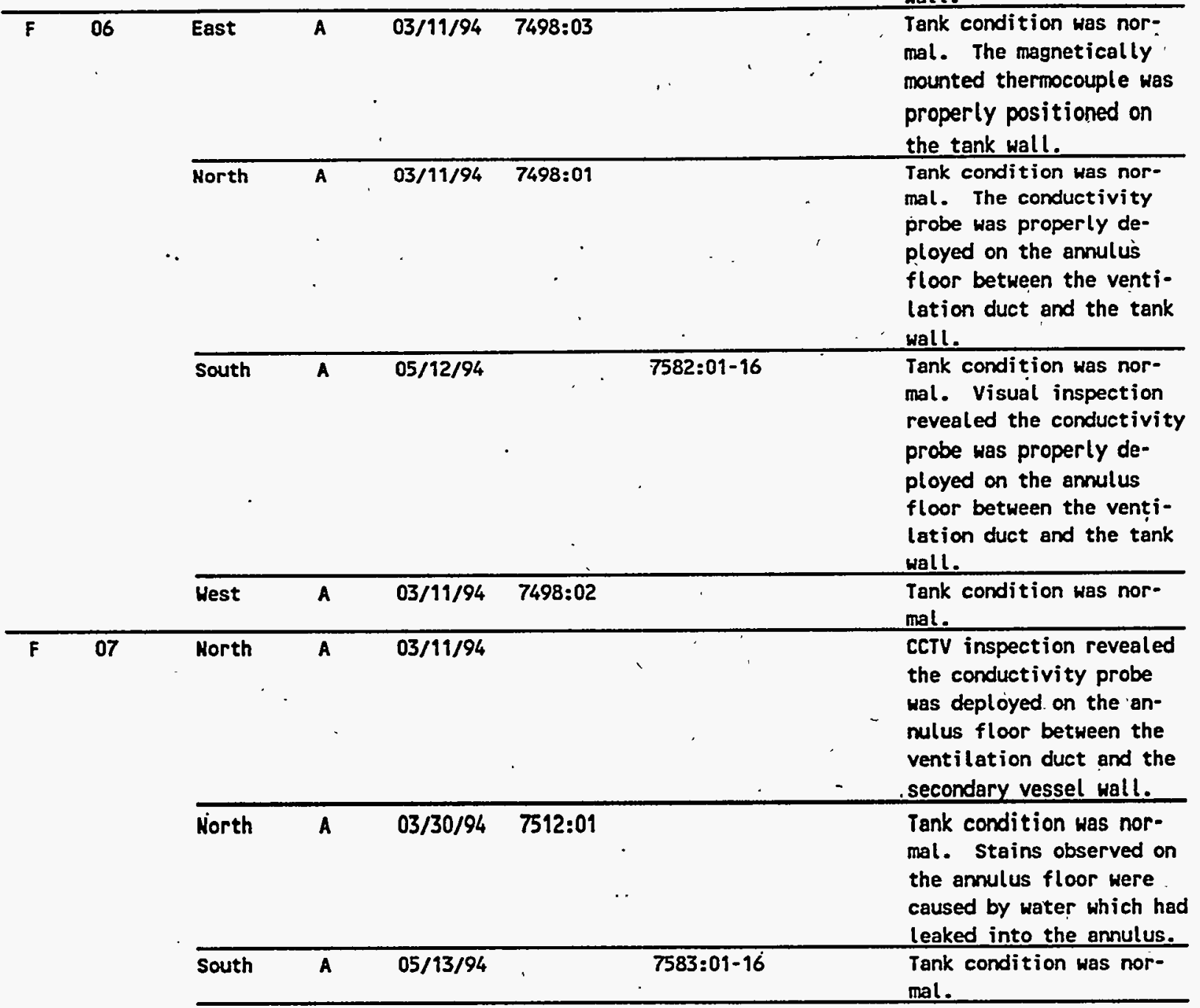




$\begin{array}{cccc}\begin{array}{c}\text { Tank } \\ \text { or }\end{array} & \begin{array}{c}\text { Inspec- Annulus } \\ \text { tion } \\ \text { Por }\end{array} & \begin{array}{c}\text { Type of Inspection and } \\ \text { Identification Numbers }\end{array} \\ \text { Area Ancillary } & \frac{\text { Port }}{07} & \frac{\text { Interior }}{\text { South. }} & \frac{\text { Date }}{06 / 22 / 94}\end{array}$

\begin{tabular}{llll}
\hline Hest & A & $03 / 30 / 94$ & $7512: 02$
\end{tabular}
secondary vessel wall. Tank condition was normal. Stains observed on the annulus floor were caused by water which had leaked into the annulus. The magnetically mounted thermocouple was properly positioned on the tank wall.

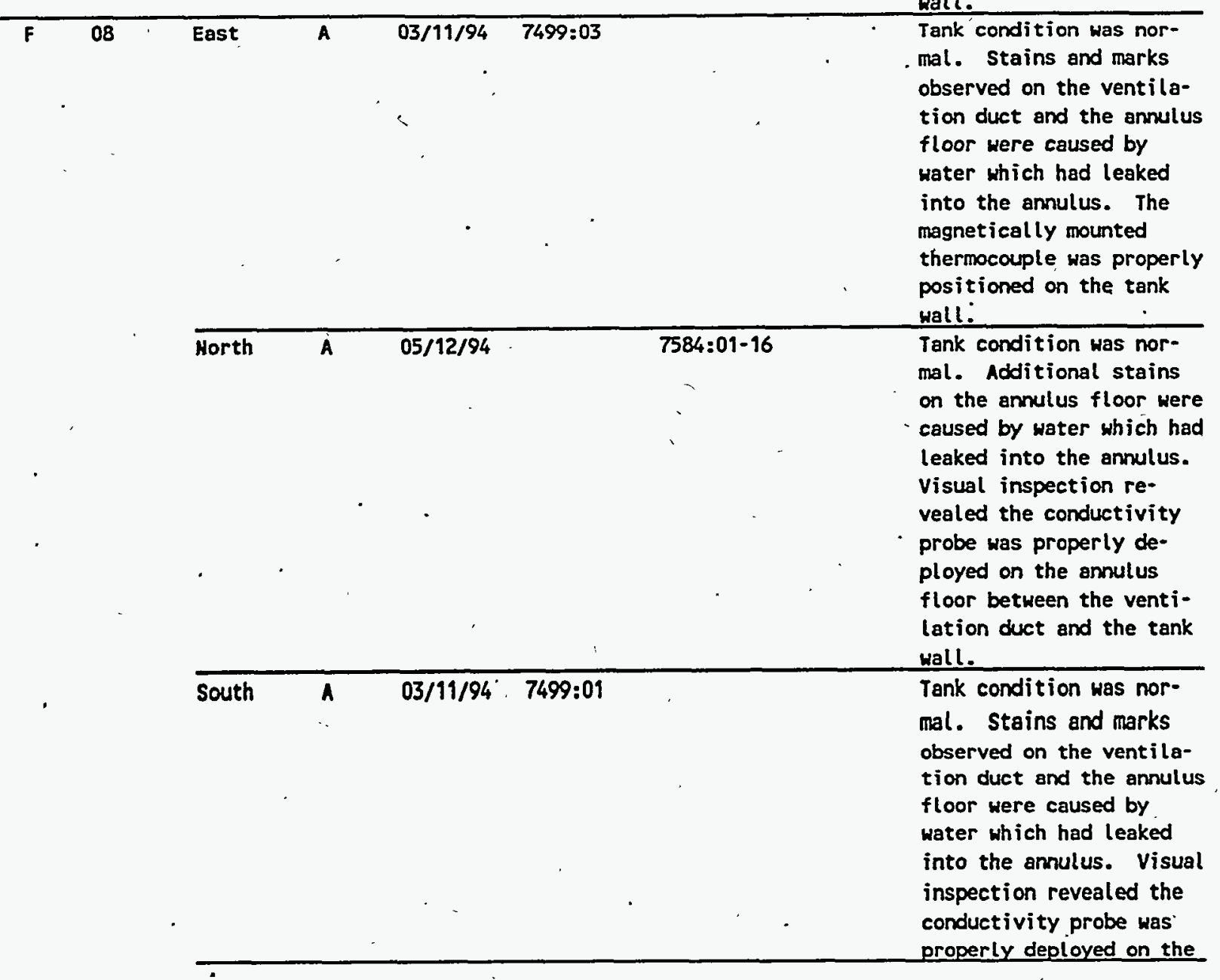




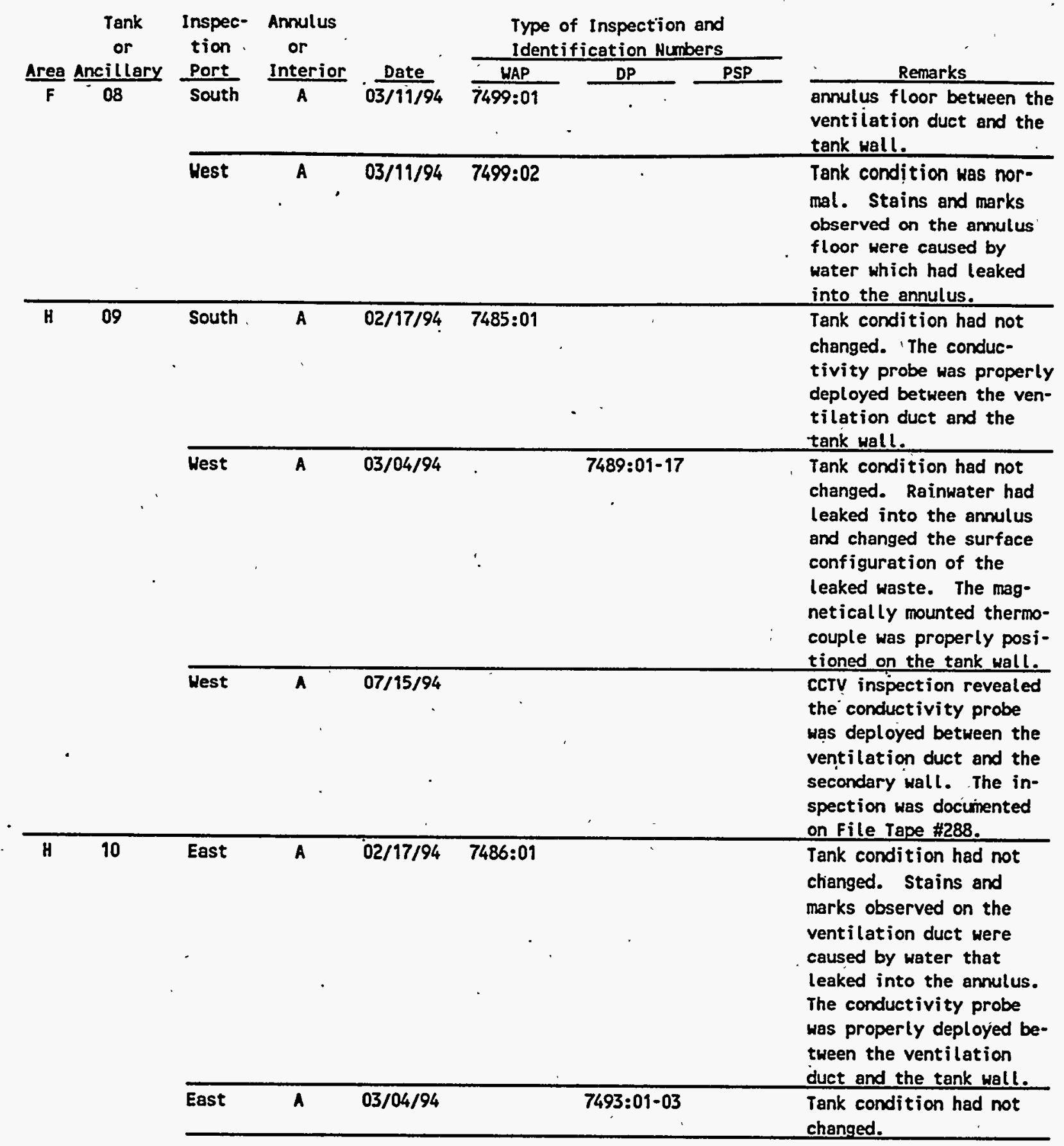




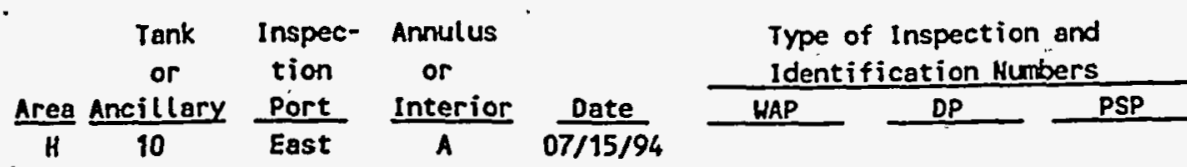

$\frac{\text { Remarks }}{\text { CCTV inspection revealed }}$ the magnetically mounted thermocouple was properly positioned on the tank wall. The inspection was documented on file Tape \#288.

\begin{tabular}{llll}
\hline North & A & $06 / 10 / 94$ & $7658: 01-17$ \\
\hline North & A & $09 / 26 / 94$ &
\end{tabular}

Tank condition had not changed.

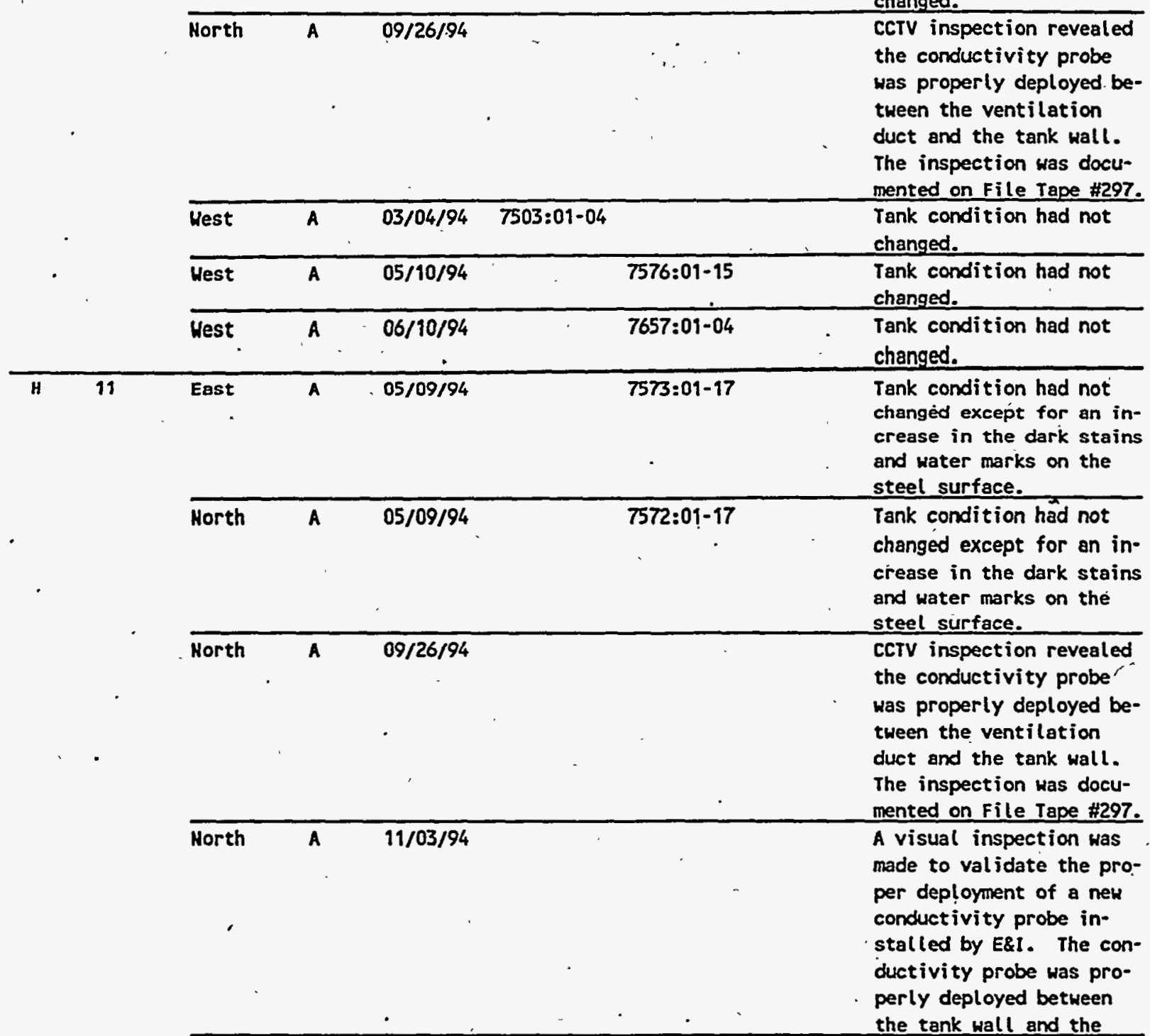




\begin{tabular}{|c|c|c|c|c|c|c|c|c|}
\hline \multirow{2}{*}{ Area } & \multirow{2}{*}{ 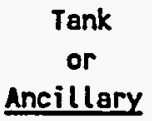 } & \multirow{2}{*}{$\begin{array}{l}\text { Inspec- } \\
\text { tion } \\
\text { Port } \\
\end{array}$} & \multirow{2}{*}{$\begin{array}{l}\text { Annulus } \\
\text { or } \\
\text { Interior }\end{array}$} & \multirow[b]{2}{*}{ Date } & \multicolumn{3}{|c|}{$\begin{array}{l}\text { Type of Inspection and } \\
\text { Identification Humbers }\end{array}$} & \multirow[b]{2}{*}{ Rèmarks } \\
\hline & & & & & HAP & DP & PSP & \\
\hline \multirow[t]{5}{*}{ H } & 11 & North & A & $11 / 03 / 94$ & & & & ventilation duct. \\
\hline & & South & $A$ & $02 / 17 / 94$ & $7487: 01$ & & & $\begin{array}{l}\text { Tank condition had not } \\
\text { changed. }\end{array}$ \\
\hline & & South & A & $07 / 15 / 94$ & $\sim$ & & & $\begin{array}{l}\text { CCTV inspection was made } \\
\text { to val idate proper de- } \\
\text { ployment of the conduc- } \\
\text { tivity probe. Results } \\
\text { were inconclusive. The } \\
\text { conductivity probe cable } \\
\text { was visible leading to } \\
\text { the proper location for } \\
\text { the probe; however, the } \\
\text { ventilation duct obscured } \\
\text { view of the probe. }\end{array}$ \\
\hline & & South & A & $09 / 26 / 94$ & $\therefore$ & & & $\begin{array}{l}\text { CCTV inspection revealed } \\
\text { the conductivity probe } \\
\text { was properly deployed be- } \\
\text { tween the ventilation } \\
\text { duct and the tank wall. } \\
\text { The inspection was docu- } \\
\text { mented on File Tape \#297. }\end{array}$ \\
\hline & & West & A & $02 / 17 / 94$ & $7487: 02$ & 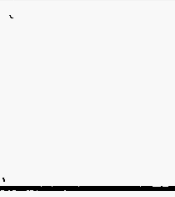 & & $\begin{array}{l}\text { Tank condition had not } \\
\text { changed. The magnetical- } \\
\text { ly mounted themocouple } \\
\text { was properly positioned } \\
\text { on the tank wall. }\end{array}$ \\
\hline \multirow[t]{4}{*}{ H } & 12 & East & A & $02 / 17 / 94$ & $7488: 02$ & mo & & $\begin{array}{l}\text { Tank condition had not } \\
\text { changed. The magnetical- } \\
\text { ly mounted thermocouple } \\
\text { was positioned approxi- } \\
\text { mately } 3 \text { feet above the } \\
\text { bottom girth weld. }\end{array}$ \\
\hline & - & North & A & 05/09/94 & & $7574: 01-16$ & & $\begin{array}{l}\text { Tank condition had not } \\
\text { changed. }\end{array}$ \\
\hline & & North & A & $10 / 07 / 94$ & & & & $\begin{array}{l}\text { A visual inspection was } \\
\text { made to verify the de- } \\
\text { ployment of the conduc- } \\
\text { tivity probe. The probe } \\
\text { cáble could be seen lead- } \\
\text { ing downward and dis- } \\
\text { appearing beneath the } \\
\text { ventilation duct. }\end{array}$ \\
\hline & & North & A & $12 / 07 / 94$ & & & & $\begin{array}{l}\text { Visual inspection was } \\
\text { performed to validate the } \\
\text { deployment of the conduc- } \\
\text { tivity probe. The con- } \\
\text { ductivity probe was pro- }\end{array}$ \\
\hline
\end{tabular}




\begin{tabular}{|c|c|c|c|c|c|c|}
\hline $\begin{array}{c}\text { Tank } \\
\text { or }\end{array}$ & $\begin{array}{l}\text { Inspec- } \\
\text { tion }\end{array}$ & $\begin{array}{l}\text { Annulus } \\
\text { or }\end{array}$ & " & & spec & \\
\hline rea Ancillary & Port & Interior & Date & WAP & DP & PSP \\
\hline H 12 & $\overline{\text { North }}$ & $A$ & $1 \overline{2 / 07 / 94}$ & & & \\
\hline
\end{tabular}

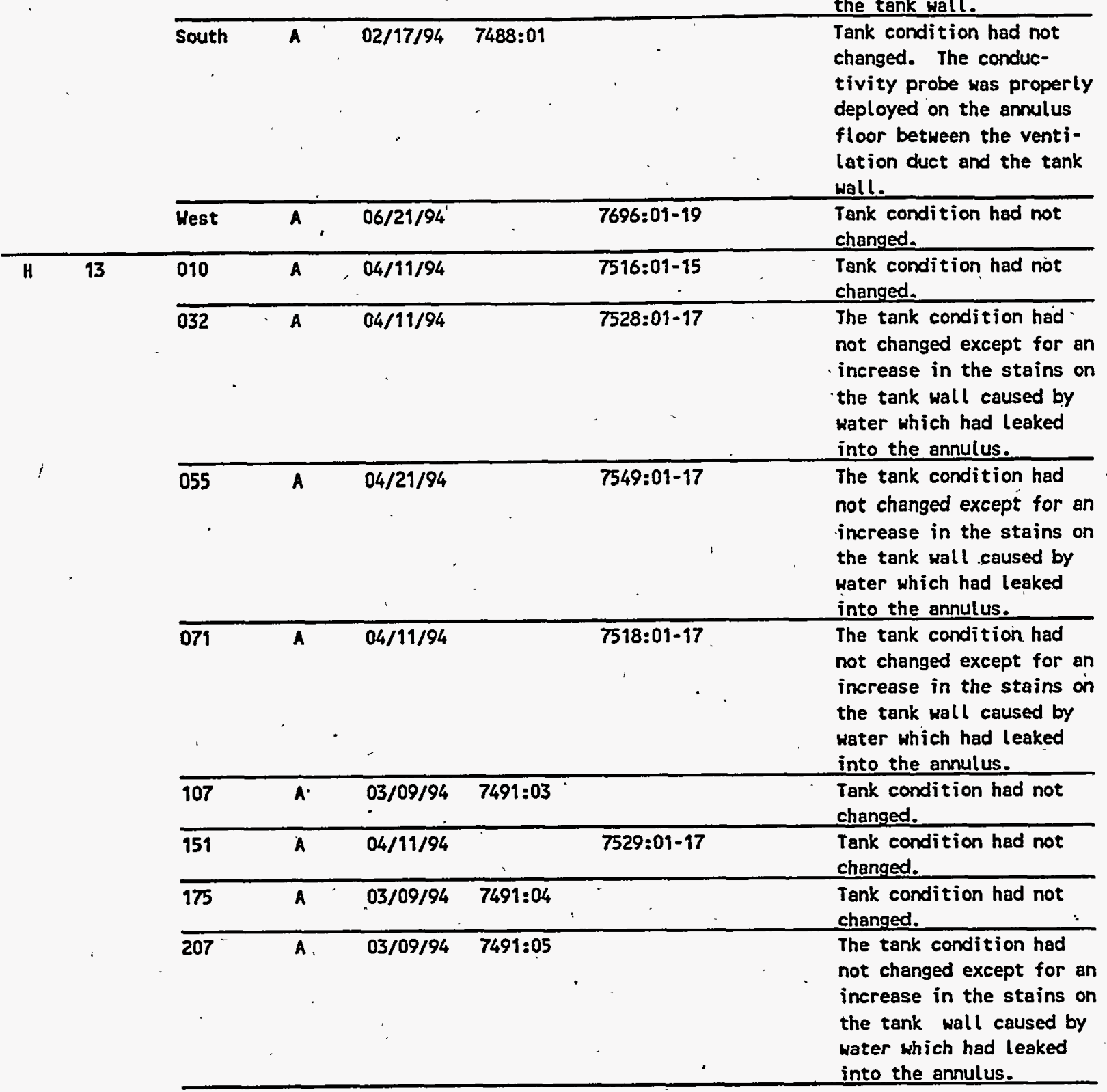
the ventilation duct and the tank wall. 


\begin{tabular}{|c|c|c|c|c|c|c|}
\hline $\begin{array}{l}\text { Tank } \\
\text { or }\end{array}$ & $\begin{array}{l}\text { Inspec- } \\
\text { tion }\end{array}$ & $\begin{array}{l}\text { Annulus } \\
\text { or }\end{array}$ & , & & $\begin{array}{l}\text { Inspection } \\
\text { ication Hum }\end{array}$ & \\
\hline Area Ancillary & Port & Interior & Date & HAP & DP & PSP \\
\hline $\bar{H} \frac{13}{13}$ & 228 & A & $0 \overline{4 / 21 / 94}$ & & $\overline{7550: 01-14}$ & \\
\hline
\end{tabular}

The tank condition had not changed except for an increase in the stains on the tank wall caused by water which had leaked into the annulus.

\begin{tabular}{llllll}
\hline East & A & $03 / 09 / 94$ & $7491: 02$ & & $\begin{array}{l}\text { Tank condition had not } \\
\text { changed. }\end{array}$ \\
\hline North & A & $04 / 28 / 94$ & & $7551: 01-16$ & $\begin{array}{l}\text { Tank condition had not } \\
\text { changed. }\end{array}$ \\
\hline
\end{tabular}
CCTV inspection was made to validate the deployment of the conductivity probe and the magnetically mounted thermocouple. The probe was properly deployed between the ventilation duct and the tank wall. The thermocouple was not properly positioned on the tank wall.

\begin{tabular}{|c|c|c|c|c|}
\hline South & A & $04 / 29 / 94$ & $7556: 01-17$ & $\begin{array}{l}\text { Tank condition had not } \\
\text { changed. }\end{array}$ \\
\hline
\end{tabular}
CCTV inspection was made to validate the deployment of the conductivity probe. The probe was positioned under the ventilation duct. The inspection was documented on File Tape \#297.

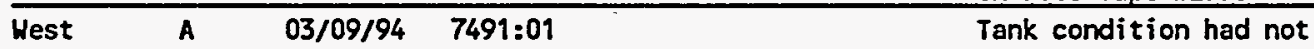
changed. Changes in the deposits on the tank wall were caused by water which had leaked into the annulus.

\begin{tabular}{llllll}
\hline H 14 & 013 & A & $03 / 31 / 94$ & $7514: 08$ & $\begin{array}{l}\text { 8nnulus. } \\
\text { fank condition had not } \\
\text { changed. }\end{array}$ \\
\hline & 032 & A & $03 / 31 / 94$ & $7514: 09$ & $\begin{array}{l}\text { Tank condition had not } \\
\text { changed. }\end{array}$ \\
\hline 065 & A & $05 / 05 / 94$ & & $7560: 01-15$. & $\begin{array}{l}\text { Tank condition had not } \\
\text { changed. }\end{array}$ \\
\hline
\end{tabular}




\begin{tabular}{|c|c|c|c|c|c|c|c|c|}
\hline \multirow{2}{*}{ Area } & \multirow{2}{*}{$\begin{array}{c}\text { Tank } \\
\text { or } \\
\text { Ancillary }\end{array}$} & \multirow{2}{*}{$\begin{array}{c}\text { Inspec- } \\
\text { tion } \\
\text { Port } \\
\end{array}$} & \multirow{2}{*}{$\begin{array}{l}\text { Annulus } \\
\text { or } \\
\text { Interior }\end{array}$} & \multirow[b]{2}{*}{ Date } & \multicolumn{3}{|c|}{$\begin{array}{l}\text { Type of Inspection and } \\
\text { Identification Numbers }\end{array}$} & \multirow[b]{2}{*}{ Remarks } \\
\hline & & & & & HAP & DP & PSP & \\
\hline H & 14 & 108 & A & $05 / 05 / 94$ & & $7561: 01-17$ & & $\begin{array}{l}\text { Tank condition had not } \\
\text { changed. }\end{array}$ \\
\hline & . & 118 & A & $05 / 05 / 94$ & & $7562: 01-15$ & & $\begin{array}{l}\text { Tank condition had not } \\
\text { changed. }\end{array}$ \\
\hline & & 125 & A & $05 / 05 / 94$ & . & $7563: 01-17$ & & $\begin{array}{l}\text { Tank condition had not } \\
\text { changed. }\end{array}$ \\
\hline & & .151 & A & $03 / 31 / 94$ & $7514: 02$ & & & $\begin{array}{l}\text { Tank condition had not } \\
\text { changed. }\end{array}$ \\
\hline & ' & 170 & $A$ & $03 / 31 / 94$ & $7514: 03$ & & & $\begin{array}{l}\text { Tank condition had not } \\
\text { changed. }\end{array}$ \\
\hline & & 207 & A & $03 / 31 / 94$. & $7514: 05$ & • & & $\begin{array}{l}\text { Tank condition had not } \\
\text { changed. }\end{array}$ \\
\hline & - & 235 & A & $03 / 31 / 94$ & $7514: 06$ & & & $\begin{array}{l}\text { Tank condition had not } \\
\text { changed. }\end{array}$ \\
\hline & $\cdot$ & 259 & A & $03 / 31 / 94$ & $7514: 07$ & . & & $\begin{array}{l}\text { Tank condition had not } \\
\text { changed. Stains observed } \\
\text { on the ventilation duct } \\
\text { were caused by water } \\
\text { which had leaked into the } \\
\text { annulus. }\end{array}$ \\
\hline & & East & A & $03 / 31 / 94$ & $7514: 04$ & a & & $\begin{array}{l}\text { Tank condition had not } \\
\text { changed. }\end{array}$ \\
\hline • & & East & A & $09 / 21 / 94$ & . & - & & $\begin{array}{l}\text { CCTV inspection revealed } \\
\text { the conductivity probe } \\
\text { was properly deployed be- } \\
\text { tween the ventilation } \\
\text { duct and the tank wall. } \\
\text { The inspection was doci- } \\
\text { mented on File Tape } \$ 297 \text {. }\end{array}$ \\
\hline & & North & A & $03 / 31 / 94$ & $7514: 01$ & & & $\begin{array}{l}\text { Tank condition had not } \\
\text { changed. }\end{array}$ \\
\hline & - & North & A & $09 / 21 / 94$ & . & & - & $\begin{array}{l}\text { CCIV inspection was made } \\
\text { to val idate the deploy- } \\
\text { ment of the conductivity } \\
\text { probe and the magnetical- } \\
\text { ly mounted thermocouple. } \\
\text { The conductivity probe } \\
\text { was properly deployed } \\
\text { between the ventilation } \\
\text { duct and the tank wall. } \\
\text { The thermocouple was pro- } \\
\text { perly positioned on the } \\
\text { tank wall. }\end{array}$ \\
\hline
\end{tabular}




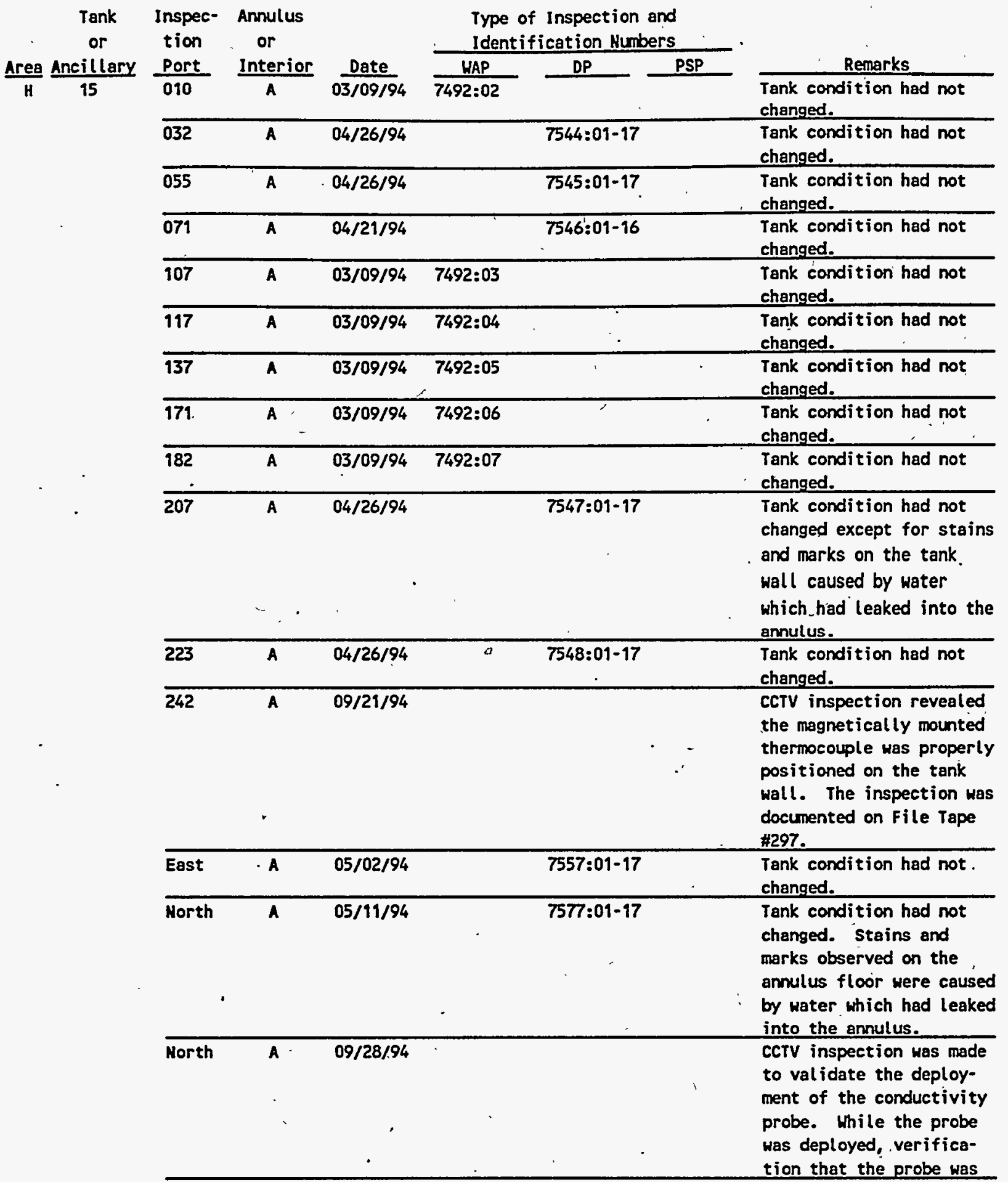




\begin{tabular}{|c|c|c|c|c|c|c|c|c|}
\hline \multirow{5}{*}{$\frac{\text { Área }}{H}$} & \multirow{5}{*}{$\begin{array}{c}\begin{array}{c}\text { Tank } \\
\text { or } \\
\text { Ancillary }\end{array} \\
\frac{15}{15}\end{array}$} & \multirow{2}{*}{$\begin{array}{l}\text { Inspec- } \\
\text { tion } \\
\text { Port } \\
\end{array}$} & \multirow{2}{*}{$\begin{array}{l}\text { Annulus } \\
\text { or } \\
\text { Interior }\end{array}$} & \multirow[b]{2}{*}{ Date } & \multicolumn{3}{|c|}{$\begin{array}{l}\text { Type of Inspection and } \\
\text { Identification Nunbers }\end{array}$} & \multirow[b]{2}{*}{ Remarks } \\
\hline & & & & & WAP & $D P$ & PSP & \\
\hline & & Horth & $A$ & $09 / 28 / 94$ & & & & $\begin{array}{l}\text { properly located was not } \\
\text { achieved due to the num- } \\
\text { erous probes and wires } \\
\text { below the riser. The in- } \\
\text { spection was documented } \\
\text { on File Tape } \$ 297 \text {. }\end{array}$ \\
\hline & & Șouth & A & $03 / 09 / 94$ & 7492:01 & & . & $\begin{array}{l}\text { Tank condition had not } \\
\text { changed. Visual inspec- } \\
\text { tion revealed the conduc- } \\
\text { tivity probe was properly } \\
\text { deployed on the annulus } \\
\text { floor between the venti- } \\
\text { lation duct and the tank } \\
\text { wall. }\end{array}$ \\
\hline & & West & A & $05 / 06 / 94$ & & $7564: 01-19$ & & $\begin{array}{l}\text { Tank condition had not } \\
\text { changed. }\end{array}$ \\
\hline H & 16 & 035 & A. & $03 / 31 / 94$ & $7513: 04$ & . & & $\begin{array}{l}\text { Tank condition had not } \\
\text { changed. }\end{array}$ \\
\hline - & & 118 & A & $03 / 31 / 94$ & $7513: 01$ & & & $\begin{array}{l}\text { Tank condition had not } \\
\text { changed. }\end{array}$ \\
\hline & & 207 & A & $03 / 31 / 94$ & 7513:02 & $\dot{-}$ & & $\begin{array}{l}\text { Tank condition had not } \\
\text { changed except for stains } \\
\text { and marks on the tank } \\
\text { wall caused by water } \\
\text { which had leaked into the } \\
\text { annulus. }\end{array}$ \\
\hline . & & 262 & A & $03 / 31 / 94$ & $7513: 03$ & - & - & $\begin{array}{l}\text { Tank condition had not } \\
\text { changed. Appearance of } \\
\text { stains and deposits on } \\
\text { the annulus floor had } \\
\text { been altered by wet con- } \\
\text { ditions that prevailed } \\
\text { during steam outage to } \\
\text { the ventilation air pre- } \\
\text { heater. }\end{array}$ \\
\hline & . & 262 & A & $\begin{array}{c}09 / 26 / 94 \\
1\end{array}$ & - & . & & $\begin{array}{l}\text { CCTV inspection was made } \\
\text { to validate the deploy- } \\
\text { ment of the conductivity } \\
\text { probe beneath the south } \\
\text { riser. The probe could } \\
\text { not be observed since the } \\
\text { area beneath the south } \\
\text { riser was out of view of } \\
\text { the camera. Inspection } \\
\text { was made from port } 262 \\
\text { because there was no in- } \\
\text { spection access port in }\end{array}$ \\
\hline
\end{tabular}




\begin{tabular}{|c|c|c|c|c|c|c|}
\hline \multirow{3}{*}{$\begin{array}{c}\begin{array}{c}\text { Tank } \\
\text { or } \\
\text { Area Ancil lary } \\
16\end{array} \\
16\end{array}$} & \multirow{2}{*}{$\begin{array}{l}\text { Inspec- } \\
\text { tion } \\
\text { Port } \\
\end{array}$} & \multirow{2}{*}{$\begin{array}{l}\text { Annulus } \\
\text { or } \\
\text { Interior } \\
\end{array}$} & \multirow{3}{*}{ Date } & \multicolumn{3}{|c|}{$\begin{array}{l}\text { Type of Inspection and } \\
\text { Identification Numbers }\end{array}$} \\
\hline & & & & WAP & OP & PSP \\
\hline & 262 & A & & & & . \\
\hline
\end{tabular}

the south riser. The inspection was documented on File Tape \#297.

\begin{tabular}{llll}
\hline East & A & $05 / 06 / 94$ & $7565: 01-17$ \\
\hline East & A & $09 / 26 / 94$
\end{tabular}
Tank condition had not changed.

CCTV inspection was made to validate the deployment of the conductivity probe. The probe could not be observed because view of the area beneath the riser was blocked by the transfer jet. The inspection was documented on File Tape \#297.

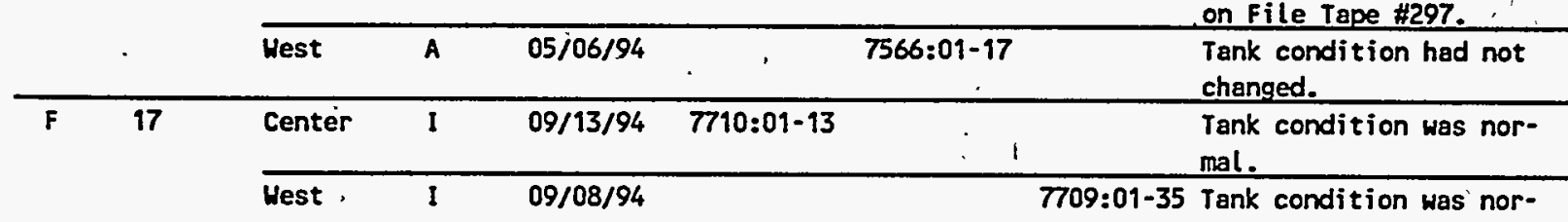

\begin{tabular}{lllllll}
\hline F & 18 & Center & I & $08 / 25 / 94$ & $7707: 01-12$ \\
\hline F & 19 & East & I & $11 / 09 / 94$ & $7714: 01-10$
\end{tabular}
mal.

Tank condition was normal. Inspection revealed a failure (a site of in(eakage) in the steel liner located in the ESE wall approximately 330" above the tank bottom.

West I 09/15/94 7711:01-36 Inspection revealed a
faiture (a site of inleakage) in the steel liner on the SW wall approximately $317^{\prime \prime}$ above the tank bottom.

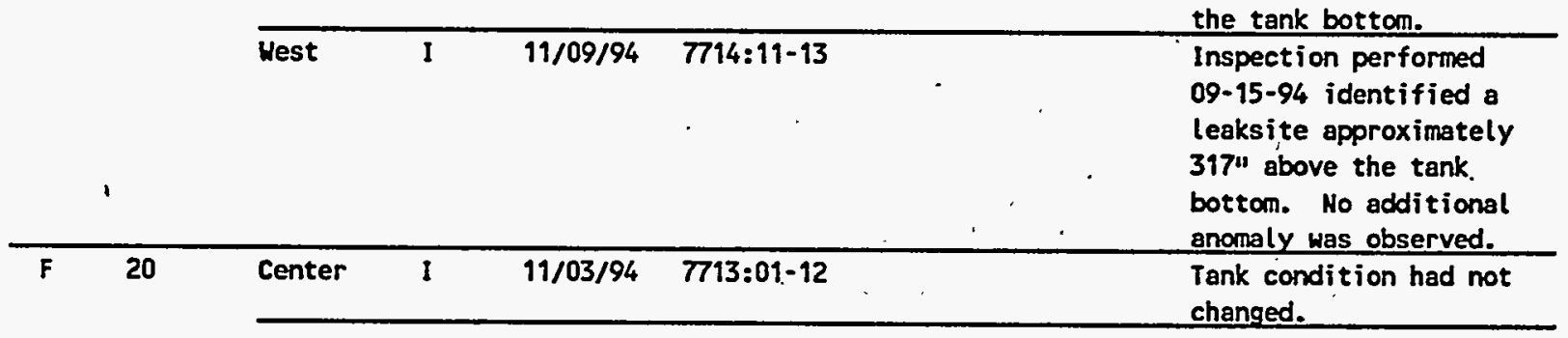




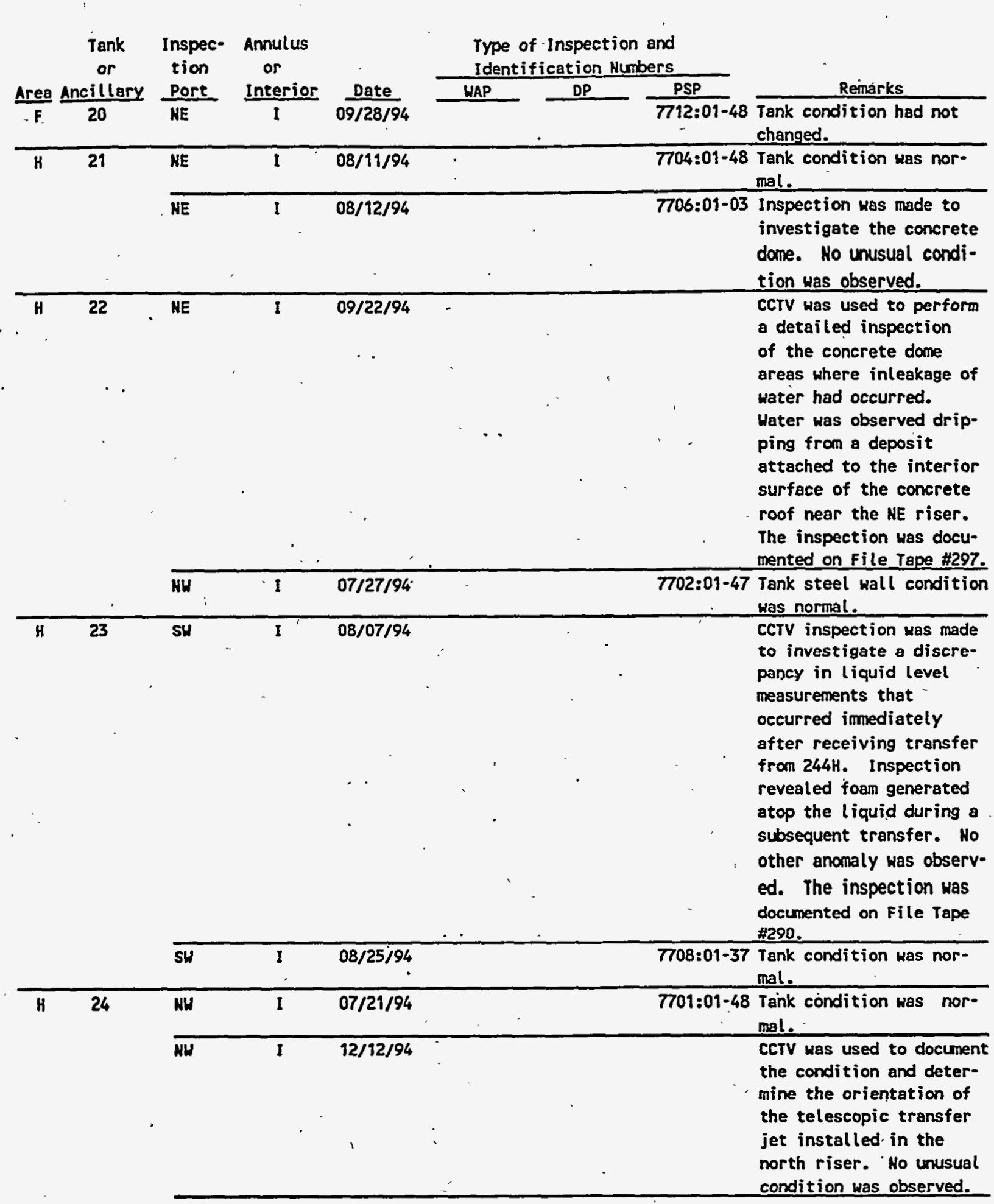




\begin{tabular}{|c|c|c|c|c|c|c|c|c|}
\hline \multirow{3}{*}{$\frac{\text { Area }}{H}$} & \multirow{2}{*}{$\begin{array}{c}\text { Tank } \\
\text { "or } \\
\text { Ancillary }\end{array}$} & \multirow{2}{*}{$\begin{array}{l}\text { Inspec- } \\
\text { tion } \\
\text { Port } \\
\end{array}$} & \multirow{2}{*}{$\begin{array}{l}\text { Annulus } \\
\text { or } \\
\text { Interior }\end{array}$} & \multirow{2}{*}{ Date } & \multicolumn{3}{|c|}{$\begin{array}{l}\text { Type of Inspection and } \\
\text { Identification Numbers }\end{array}$} & \multirow[b]{2}{*}{ Remarks } \\
\hline & & & & & WAP & $\mathrm{DP}$ & PSP & \\
\hline & 24 & & $I$ & 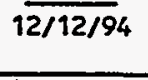 & & & & $\begin{array}{l}\text { The inspection was docu- } \\
\text { mented on File Tape } \$ 306 \text {. }\end{array}$ \\
\hline \multirow[t]{15}{*}{$\mathbf{F}$} & 25 & A-01 & A & $06 / 06 / 94$ & $7651: 01$ & & & $\begin{array}{l}\text { Tank condition was nor- } \\
\text { mal. }\end{array}$ \\
\hline & & $A-02$ & A & $06 / 06 / 94$ & $7651: 02$ & & . & $\begin{array}{l}\text { Tank condition was nor- } \\
\text { mal. The conductivity } \\
\text { probe was properly de- } \\
\text { ployed on the annulus } \\
\text { floor. }\end{array}$ \\
\hline & & $A-03$ & A & $\begin{array}{c}06 / 06 / 94 \\
.\end{array}$ & $7651: 03$ & & & $\begin{array}{l}\text { Tank condition was nor- } \\
\text { mal. The conductivity } \\
\text { probe was suspended } 1-2 \\
\text { inches above the annulus } \\
\text { floor: }\end{array}$ \\
\hline & & $A-03$ & A & $11 / 17 / 94$ & & & & $\begin{array}{l}\text { Visual inspection reveal- } \\
\text { ed the conductivity probe } \\
\text { was properly deployed on } \\
\text { the annulus floor. }\end{array}$ \\
\hline & & $A-04$ & A & $06 / 06 / 94$ & $7651: 04$ & . & & $\begin{array}{l}\text { Tank condition was nor- } \\
\text { mal. The conductivity } \\
\text { probe was properly de- } \\
\text { ployed on the annulus } \\
\text { floor. }\end{array}$ \\
\hline & & P-01 & A & $06 / 06 / 94$ & $7651: 05$ & & & $\begin{array}{l}\text { Tank condition was nor- } \\
\text { mal. }\end{array}$ \\
\hline & & $P-02$ & A & $06 / 06 / 94$ & $7651: 06$ & & & $\begin{array}{l}\text { Tank condition was nor- } \\
\text { mal. }\end{array}$ \\
\hline & & P-03 & $A$ & $06 / 06 / 94$ & $7651: 07$ & & & $\begin{array}{l}\text { Tank condition was nor- } \\
\text { mal. }\end{array}$ \\
\hline & & $P-04$ & A & $06 / 06 / 94$ & $7651: 08$ & & & $\begin{array}{l}\text { Tank condition was nor- } \\
\text { mal. }\end{array}$ \\
\hline & & $P-05$ & A & $06 / 02 / 94$ & & $7631: 01-25$ & & $\begin{array}{l}\text { Tank condition was nor- } \\
\text { mal. }\end{array}$ \\
\hline & & $P-06$ & A & $06 / 07 / 94$ & & $7671: 01-25$ & & $\begin{array}{l}\text { Tank condition was nor- } \\
\text { mal. }\end{array}$ \\
\hline & & $p-07$ & $\mathbf{A}$ & $06 / 06 / 94$ & $7651: 09$ & & & $\begin{array}{l}\text { Tank condition was nor- } \\
\text { mal. }\end{array}$ \\
\hline & & P-08 & A & $0.6 / 06 / 94$ & $7651: 10$ & & & $\begin{array}{l}\text { Tank condition was nor- } \\
\text { mal. }\end{array}$ \\
\hline & & P-09 & $\mathbf{A}$ & $06 / 06 / 94$ & $7651: 11$ & & & $\begin{array}{l}\text { Tank condition was nor- } \\
\text { mal. }\end{array}$ \\
\hline & & $p-10$ & A & $06 / 02 / 94$ & & $7632: 01-25$ & & $\begin{array}{l}\text { Tank condition was nor- } \\
\text { mal. }\end{array}$ \\
\hline
\end{tabular}




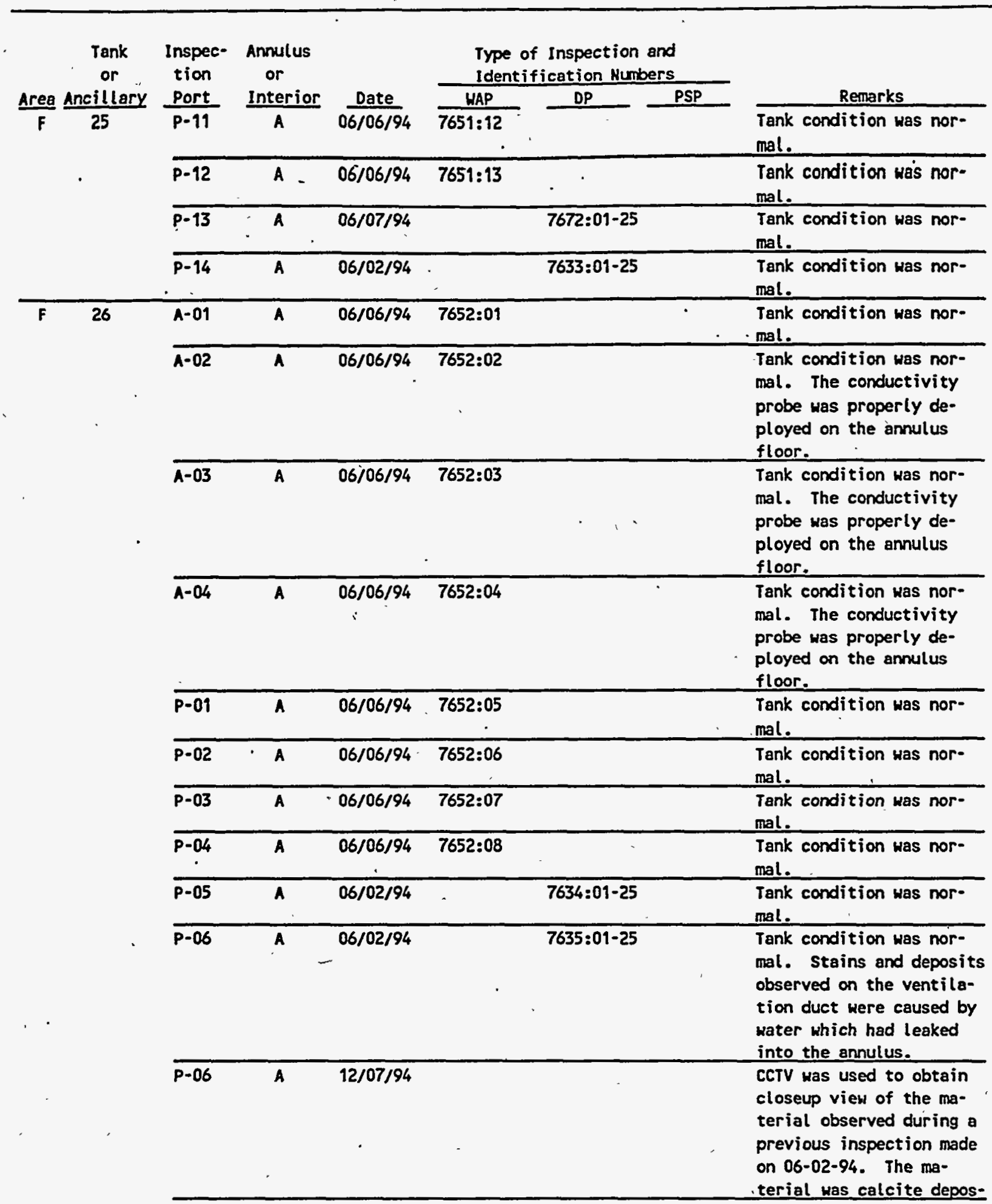




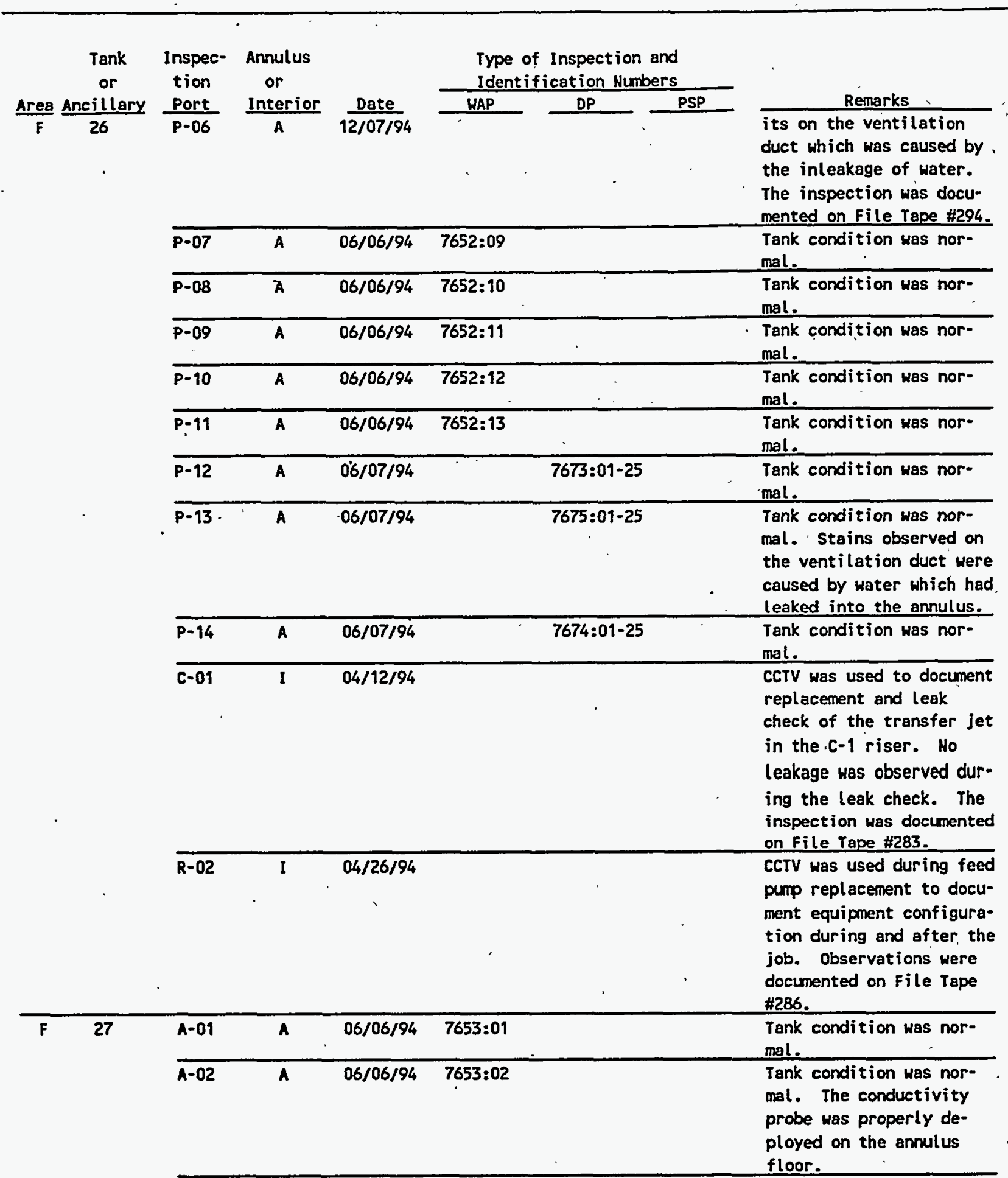




\begin{tabular}{|c|c|c|c|c|c|c|}
\hline \multirow{2}{*}{ 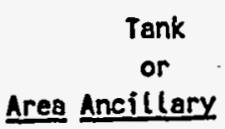 } & \multirow{2}{*}{$\begin{array}{c}\text { Inspec- } \\
\text { tion } \\
\text { Port } \\
\end{array}$} & \multirow{2}{*}{$\begin{array}{l}\text { Annulus } \\
\text { or } \\
\text { Interjor }\end{array}$} & \multirow[b]{2}{*}{ Date } & \multicolumn{3}{|c|}{$\begin{array}{l}\text { Type of Inspection and } \\
\text { Identification Numbers }\end{array}$} \\
\hline & & & & WAP & $\mathrm{DP}$ & PSP \\
\hline$F \quad 27$ & $A-03$ & A & $06 / 06 / 94$ & $7653: 03$ & & \\
\hline
\end{tabular}

Remarks

Tank condition was nor: mal. The conductivity probe was properly deployed on the annulus floor.

A-04, A, 06/06/94 7653:04 Tank condition was nor-
mal. The conductivity probe was properly deployed on the anrulus floor.

\begin{tabular}{llllll}
\hline P-01 & A & $06 / 06 / 94 \cdot$ & $7653: 05$ & $\begin{array}{l}\text { Tank condition was nor- } \\
\text { mal. }\end{array}$ \\
\hline P-02 & A & $06 / 06 / 94$ & $7653: 06$ & $\begin{array}{l}\text { Tank condition was nor- } \\
\text { mal. }\end{array}$ \\
\hline P-03 & A & $06 / 06 / 94$ & $7653: 07$ & $\begin{array}{l}\text { Tank condition was nor- } \\
\text { mal. }\end{array}$ \\
\hline
\end{tabular}

\begin{tabular}{lllll}
\hline P-0 04 & A & $06 / 06 / 94$ & $7653: 08$ & Tank condition was nor-
\end{tabular}

P-05 $06 / 07 / 94 \quad$ mal.

Tank condition was normal.

P-06 A $06 / 02 / 94, \quad \cdot 7636: 01-25 \quad$ Tank condition was nor-

\begin{tabular}{lllll}
\hline P-07 A & 06/06/94 & 7653:09 & mal.
\end{tabular}

P-0B A mal.

P-08 A $\quad 06 / 06 / 94 \quad 7653: 10 \quad$ Tank condition was nor-

mal. Stains observed on the secondary vessel wall were caused by water which had leaked into the annulus.

\begin{tabular}{llllll}
\hline P-09 & A & $06 / 06 / 94$ & $7653: 11$ & & $\begin{array}{l}\text { Tank condition was nor- } \\
\text { mal. }\end{array}$ \\
\hline P-10 & A & $06 / 06 / 94$ & $7653: 12$ & $\begin{array}{l}\text { Tank condition was nor- } \\
\text { mal. }\end{array}$ \\
\hline P-11 & A & $06 / 06 / 94$ & $7653: 13$ & $\begin{array}{l}\text { Tank condition was nor- } \\
\text { mal. }\end{array}$ \\
\hline p-12 & A & $06 / 02 / 94$ & & $7637: 01-25$ & Tank condition was nor-
\end{tabular}
mal. Stains on the annulus floor were caused by water which had leaked into the annulus.

\begin{tabular}{lllll}
\hline p-13 & A & $06 / 02 / 94$ & $7638: 01-25$ & into the annulus. \\
\hline
\end{tabular}




\begin{tabular}{|c|c|c|c|c|c|c|c|c|}
\hline \multirow{3}{*}{$\frac{\text { Area }}{\mathrm{F}}$} & \multirow{2}{*}{$\begin{array}{c}\text { Tank } \\
\text { or } \\
\text { Ancil lary } \\
\end{array}$} & \multirow{2}{*}{$\begin{array}{l}\text { Inspec- } \\
\text { tion } \\
\text { Port } \\
\end{array}$} & \multirow{2}{*}{$\begin{array}{l}\text { Annulus } \\
\text { or } \\
\text { Interior }\end{array}$} & \multirow[b]{2}{*}{ Date } & \multicolumn{3}{|c|}{$\begin{array}{l}\text { Type of Inspection and } \\
\text { Identification Numbers }\end{array}$} & \multirow[b]{2}{*}{ Remarks } \\
\hline & & & & & WAP & $\mathrm{DP}$ & PSP & \\
\hline & & $p-14$ & $A$ & $\overline{06 / 02 / 94}$ & & $\overline{7639: 01-25}$ & & $\begin{array}{l}\text { Tank condition was nor- } \\
\text { mal. }\end{array}$ \\
\hline \multirow[t]{12}{*}{$F$} & 28 & $A-01$ & A & $05 / 27 / 94$ & $7624: 01$ & . & & $\begin{array}{l}\text { Tank condition was nor- } \\
\mathrm{mal.}\end{array}$ \\
\hline & & A-01 & A. & $07 / 05 / 94$ & & - & & $\begin{array}{l}\text { CcTV investigation re- } \\
\text { vealed the mass on the } \\
\text { annulus floor was a cal- } \\
\text { cite deposit caused by } \\
\text { inleakage of rainwater. } \\
\text { The small mass had not } \\
\text { increased in size since } \\
\text { first observed in } 1983 . \\
\text { The inspection was docu- } \\
\text { mented on Flle Tape \#288. }\end{array}$ \\
\hline & $\cdot$ & $A-02$ & $A$ & $05 / 27 / 94$ & $7624: 02$ & & & $\begin{array}{l}\text { Tank condition was nor- } \\
\text { mal. The conductivity } \\
\text { probe was properly de- } \\
\text { ployed on the annulus } \\
\text { floor. }\end{array}$ \\
\hline & - & $A-03$ & A & $05 / 27 / 94$ & $7624: 03$ & , & & $\begin{array}{l}\text { Tank condition was nor- } \\
\text { mal. The conductivity } \\
\text { probe was properly de- } \\
\text { ployed on the annulus } \\
\text { floor. }\end{array}$ \\
\hline & & $A-04$ & A & $05 / 27 / 94$ & $7624: 04$ & . & & $\begin{array}{l}\text { Tank condition was nor- } \\
\text { mal. The conductivity } \\
\text { probe was properly de- } \\
\text { ployed' on the annulus } \\
\text { floor. }\end{array}$ \\
\hline & & P-01 & $A$ & $05 / 27 / 94$ & $7624: 05$ & & & $\begin{array}{l}\text { Tank çondition was nor- } \\
\text { mal. }\end{array}$ \\
\hline & & P-02 & $A$ & $06 / 08 / 94$ & & $7677: 01-25$ & & $\begin{array}{l}\text { Tank condition was nor- } \\
\mathrm{mal} \text {. }\end{array}$ \\
\hline & & $p-03$ & $A$ & $05 / 27 / 94$ & $7624: 06$ & & & $\begin{array}{l}\text { Tank condition yas nor- } \\
\text { mal. }\end{array}$ \\
\hline & & $P=04$ & A & $05 / 27 / 94$ & $7624: 07$ & . & & $\begin{array}{l}\text { Tank condition was nor- } \\
\text { mal. }\end{array}$ \\
\hline & & P-05 & A & $06 / 08 / 94$ & & $7678: 01-25$ & & $\begin{array}{l}\text { Tank condition was nor- } \\
\text { mal. }\end{array}$ \\
\hline & 1 & P-06 & A & $05 / 27 / 94$ & $7624: 08$ & & & $\begin{array}{l}\text { Tank condition was nor- } \\
\text { mal. }\end{array}$ \\
\hline & & $P-07$ & A & $06 / 06 / 94$ & $7654: 01$ & . & & $\begin{array}{l}\text { Tank condition was nor- } \\
\text { mal. }\end{array}$ \\
\hline
\end{tabular}




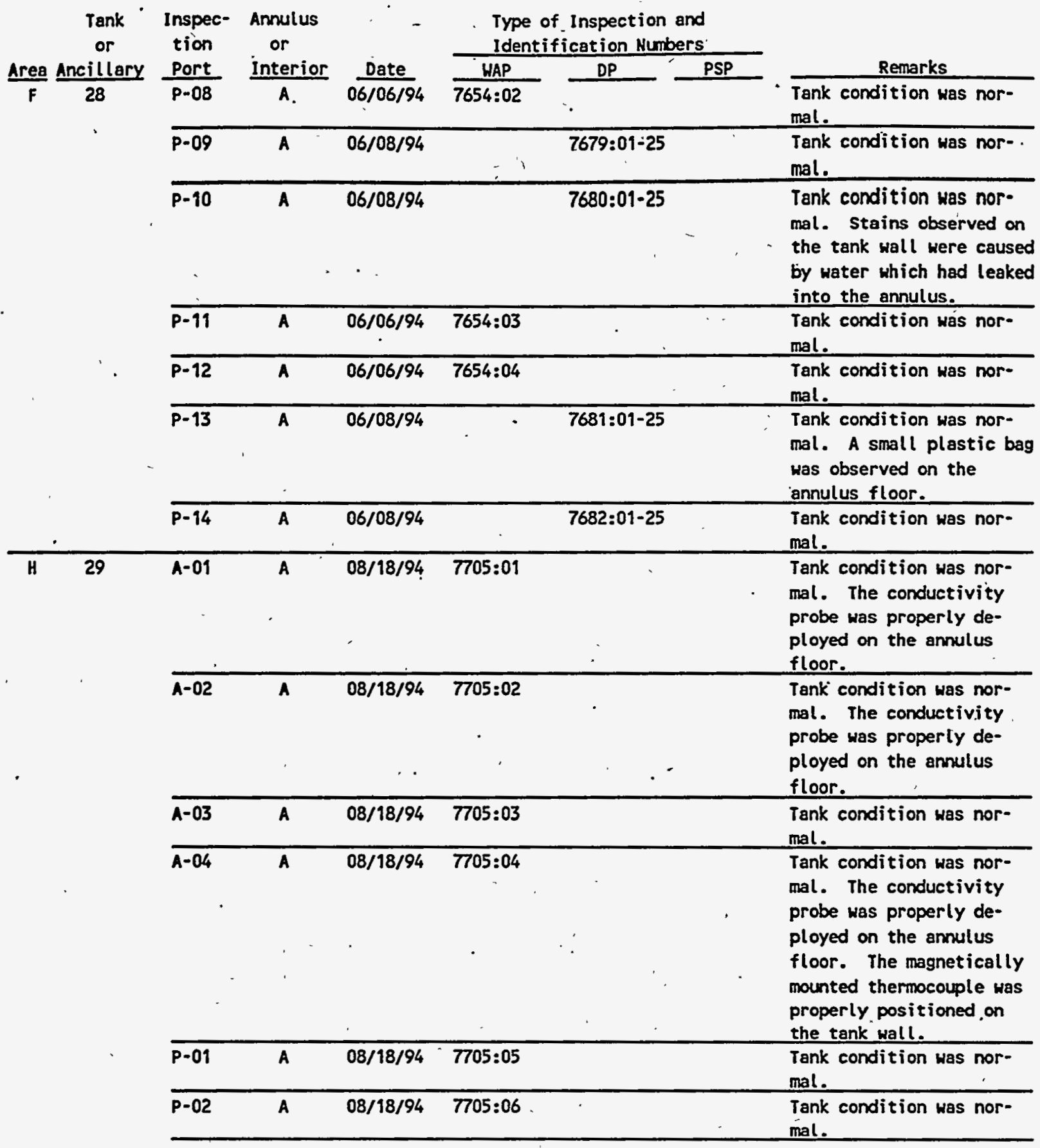




\begin{tabular}{|c|c|c|c|c|c|c|c|c|}
\hline \multirow[b]{2}{*}{ Area } & \multirow{2}{*}{$\begin{array}{c}\text { Tank } \\
\text { or } \\
\text { Ancillary } \\
\end{array}$} & \multirow{2}{*}{$\begin{array}{l}\text { Inspec- } \\
\text { tion } \\
\text { Port } \\
\end{array}$} & \multirow{2}{*}{$\begin{array}{l}\text { Annulus } \\
\text { or } \\
\text { Interjor }\end{array}$} & \multirow[b]{2}{*}{ Date } & \multicolumn{3}{|c|}{$\begin{array}{l}\text { Type of Inspection and } \\
\text { Identification Mumbers }\end{array}$} & \multirow{2}{*}{ Remarks } \\
\hline & & & & & WAP & $-\mathrm{DP}$ & PSP & \\
\hline \multirow[t]{12}{*}{ H } & & $\overline{P-03}$ & $A$ & $\overline{06 / 17 / 94}$ & & $\overline{7693: 01-25}$ & & $\begin{array}{l}\text { Tank condition was nor-. } \\
\text { mal. }\end{array}$ \\
\hline & & $P-04$ & A & $08 / 18 / 94$ & $7705: 07$ & . & & $\begin{array}{l}\text { Tank condition was nor- } \\
\text { mal. }\end{array}$ \\
\hline & & $P-05$ & A & $08 / 18 / 94$ & $7705: 08$ & . & & $\begin{array}{l}\text { Tank condition kas nor- } \\
\text { mal. }\end{array}$ \\
\hline & & P-06 & A & $06 / 17 / 94$ & & $7694: 01-25$ & & $\begin{array}{l}\text { Tank condition was nor- } \\
\text { mal. }\end{array}$ \\
\hline & ' & $P-07$ & A & $08 / 18 / 94^{\circ}$ & $7705: 09$ & . & & $\begin{array}{l}\text { Tank condition was nor- } \\
\text { mal. }\end{array}$ \\
\hline & & $\mathrm{P}-08$ & A & $08 / 18 / 94$ & $7705: 10$ & & & $\begin{array}{l}\text { Tank condition was nor- } \\
\text { mal. }\end{array}$ \\
\hline & & $p-09$ & A & $06 / 17 / 94$ & & $7695: 01-25$ & & $\begin{array}{l}\text { Tank condition was nor- } \\
\text { mal. }\end{array}$ \\
\hline & & $\begin{array}{c}p-10 \\
.\end{array}$ & $A$ & $06 / 28 / 94$ & & $7698: 01-25$ & & $\begin{array}{l}\text { Tank condition was nor- } \\
\text { mal. }\end{array}$ \\
\hline & & $p-11$ & A & $08 / 18 / 94$ & $7705: 11$ & . & & $\begin{array}{l}\text { Tank condition was nor- } \\
\text { mal. }\end{array}$ \\
\hline & & $p-12$ & A & $08 / 18 / 94$ & $7705: 12$ & & & $\begin{array}{l}\text { Tank condition was nor- } \\
\text { mal. Stains observed on } \\
\text { the secondary vessel wall } \\
\text { were caused by water. } \\
\text { which had leaked into the } \\
\text { annulus. }\end{array}$ \\
\hline & & $p-13$ & A & $06 / 28 / 94$ & & $7699: 01-25$ & & $\begin{array}{l}\text { Tank condition was 'nor- } \\
\text { mal. }\end{array}$ \\
\hline & & $P-14$ & A & $08 / 18 / 94$ & $7705: 13$ & & . & $\begin{array}{l}\text { Tank condition was nor- } \\
\text { mal. }\end{array}$ \\
\hline \multirow[t]{3}{*}{ H } & 30 & $A-01$ & A & $05 / 23 / 94$ & $7626: 01$ & . & , & $\begin{array}{l}\text { Tank condition was nor- } \\
\text { mal. The conductivity } \\
\text { probe was properly de- } \\
\text { ployed on the aninulus } \\
\text { ifloor: }\end{array}$ \\
\hline & & $A-02$ & $A$ & $05 / 23 / 94$ & $7626: 02$ & $\therefore$ & & $\begin{array}{l}\text { Tank condition was nor- } \\
\text { mal. The conductivity } \\
\text { probe was properly de- } \\
\text { ployed on the annulus } \\
\text { floor. }\end{array}$ \\
\hline & 、 & $A-03$ & A & $05 / 23 / 94$ & $7626: 03$ & & & $\begin{array}{l}\text { Tank condition was nor- } \\
\text { mal. Stains observed on } \\
\text { the annulus floor were } \\
\text { caused by water that } \\
\text { leaked into the annulus. }\end{array}$ \\
\hline
\end{tabular}




\begin{tabular}{|c|c|c|c|c|c|c|}
\hline $\begin{array}{l}\text { Tank } \\
\text { or }\end{array}$ & $\begin{array}{l}\text { Inspec- } \\
\text { tion }\end{array}$ & $\begin{array}{l}\text { Annulus } \\
\text { or }\end{array}$ & & & & \\
\hline ea Ancillary & Port & Interior & Date & WAP & $\mathrm{DP}$ & PSP \\
\hline H & $A-04$ & $A$ & $05 / 23 / 94$ & $7626: 04$ & & \\
\hline
\end{tabular}

Tank condition was nor$\mathrm{mal}$. The conductivity probe was properly deployed on the annulus floor. The magnetically mounted thermocouple was properly positioned on the tank wall.

\begin{tabular}{llll}
\hline P-01 & A & $05 / 23 / 94$ & $7626: 05$ \\
\hline P-02, & A & $05 / 23 / 94$ & $7626: 06$
\end{tabular}
Tank condition was normal.

Tank condition was normat. An absorbent wipe was observed on the ventilation duct.

\begin{tabular}{llllll}
\hline P-03 A & 05/23/94 & $7605: 01-25$ &. & $\begin{array}{l}\text { Tank condition was nor- } \\
\text { mal. }\end{array}$ \\
\hline
\end{tabular}

\begin{tabular}{llll}
\hline P-04 A & $05 / 23 / 94$ & $7626: 07$ \\
\hline P-05 A. & $05 / 23 / 94$ & $7626: 08$
\end{tabular}

Tank condition was normal.

\begin{tabular}{lllll}
\hline P-05 & A & $05 / 23 / 94$ & $7626: 08$ & \\
\hline P-06 & A & $05 / 23 / 94$ & & $7606: 01-25$ \\
\hline P-07 & A & $05 / 23 / 94$ & $7626: 09$ &
\end{tabular}
mal.

Tank condition was normal.

Tank condition was normal. Stains observed on the ventilation duct were caused by water which had leaked into the annulus.

\begin{tabular}{llll}
\hline P-08 A & $05 / 23 / 94$ & $7626: 10$
\end{tabular}
Tank condition was normal. Stains observed on the secondary vessel wall were caused by water which had leaked into the annulus.

\begin{tabular}{lllll}
\hline P-09 & A & $05 / 23 / 94$ & $7607: 01-25$ & $\begin{array}{l}\text { Tank condition was nor- } \\
\text { mal. }\end{array}$ \\
\hline P-10 & A & $05 / 23 / 94$ & $\begin{array}{l}\text { Tank condition was nor- } \\
\text { mal. }\end{array}$ \\
\hline P-11 & A & $05 / 23 / 9.4$ & $7626: 19$ & $\begin{array}{l}\text { Tank condition was nor- } \\
\text { mal. Stains observed on } \\
\text { the secondary vessel wall } \\
\text { were caused by water } \\
\text { which had leaked into the } \\
\text { annulus. }\end{array}$ \\
\hline
\end{tabular}




\begin{tabular}{|c|c|c|c|c|c|c|c|c|}
\hline \multirow{5}{*}{$\frac{\text { Area }}{H}$} & \multirow{2}{*}{$\begin{array}{c}\begin{array}{c}\text { Tank } \\
\text { or } \\
\text { Ancillary }\end{array} \\
30\end{array}$} & \multirow{4}{*}{$\begin{array}{l}\text { Inspec- } \\
\text { tion } \\
\text { Port } \\
P-12 \\
P-13\end{array}$} & \multirow{3}{*}{$\begin{array}{l}\text { Annulus } \\
\text { or } \\
\frac{\text { Interior }}{A}\end{array}$} & \multirow{3}{*}{$\frac{\text { Date }}{05 / 23 / 94}$} & \multicolumn{3}{|c|}{$\begin{array}{l}\text { Type of Inspection and } \\
\text { Identification Numbers }\end{array}$} & \multirow[b]{2}{*}{ Remarks } \\
\hline & & & & & WAP & $D P$ & PSP & \\
\hline & & & & & $7626: 12$ & & & $\begin{array}{l}\text { Tanḱ conditión was nor- } \\
\text { mal. }\end{array}$ \\
\hline & & & A & $05 / 23 / 94$ & & $7609: 01-25$ & & $\begin{array}{l}\text { Tank condition was nor- } \\
\text { mal. }\end{array}$ \\
\hline & & $P-14$ & A & '. & $7626: 13$ & $\because$ & & $\begin{array}{l}\text { Tank condition was nor- } \\
\text { mal. Stains and marks } \\
\text { observed on the ventila- } \\
\text { tion duct were caused by } \\
\text { water which had leaked } \\
\text { into the annulus. }\end{array}$ \\
\hline \multirow[t]{9}{*}{ H } & 31 & $A-01$ & A & $05 / 23 / 94$ & 7627:01 & , & & $\begin{array}{l}\text { Tank condition was nor- } \\
\text { mal. The conductivity } \\
\text { probe was properly de- } \\
\text { ployed on the annulus } \\
\text { floor. }\end{array}$ \\
\hline & $\cdot$ & $A-02$ & A & $05 / 23 / 94$ & $7627: 02$ & $\therefore$ & & $\begin{array}{l}\text { Tank condition was nor- } \\
\text { mal. The conductivity } \\
\text { probe was properly de- } \\
\text { ployed on the annulus } \\
\text { floor. }\end{array}$ \\
\hline & & $A-03$ & A & $05 / 23 / 94$ & $7627: 03$ & & & $\begin{array}{l}\text { Tank condition was nor- } \\
\text { mal. Stains observed on } \\
\text { the secondary vessel wall } \\
\text { were caused by water } \\
\text { which had leaked into the } \\
\text { annulus. }\end{array}$ \\
\hline & & $A-04$ & A & $05 / 23 / 94$ & $7627: 04$ & & & $\begin{array}{l}\text { Tank condition was nor- } \\
\text { mal. The conductivity } \\
\text { probe was properly de- } \\
\text { ployed on the annulus } \\
\text { floor. The magnetically } \\
\text { mounted thermocouple was } \\
\text { properly positioned on } \\
\text { the tank wall. }\end{array}$ \\
\hline & & p-01. & A & $05 / 23 / 94$ & $7627: 05$ & . & & $\begin{array}{l}\text { Tank condition was nor- } \\
\text { mal. }\end{array}$ \\
\hline & & $P-02$ & $A$ & $05 / 23 / 94$ & 7627:06 & & & $\begin{array}{l}\text { Tank condition was nor- } \\
\text { mat. }\end{array}$ \\
\hline & & $p-03$ & A & $05 / 23 / 94$ & & $7610: 01-25$ & & $\begin{array}{l}\text { Tank condition was nor- } \\
\text { mal. }\end{array}$ \\
\hline & & $p-04$ & A & $05 / 23 / 94$ & $7627: 07$ & & & $\begin{array}{l}\text { Tank condition was nor- } \\
\text { mal. }\end{array}$ \\
\hline & . & $p-05$ & A & $05 / 23 / 94$ & $\begin{array}{c}7627: 08 \\
.\end{array}$ & & & $\begin{array}{l}\text { Tank condition was nor- } \\
\text { mal. Stains observed on } \\
\text { the secondary vessel wall } \\
\text { were caused by water } \\
\text { which had leaked into the }\end{array}$ \\
\hline
\end{tabular}




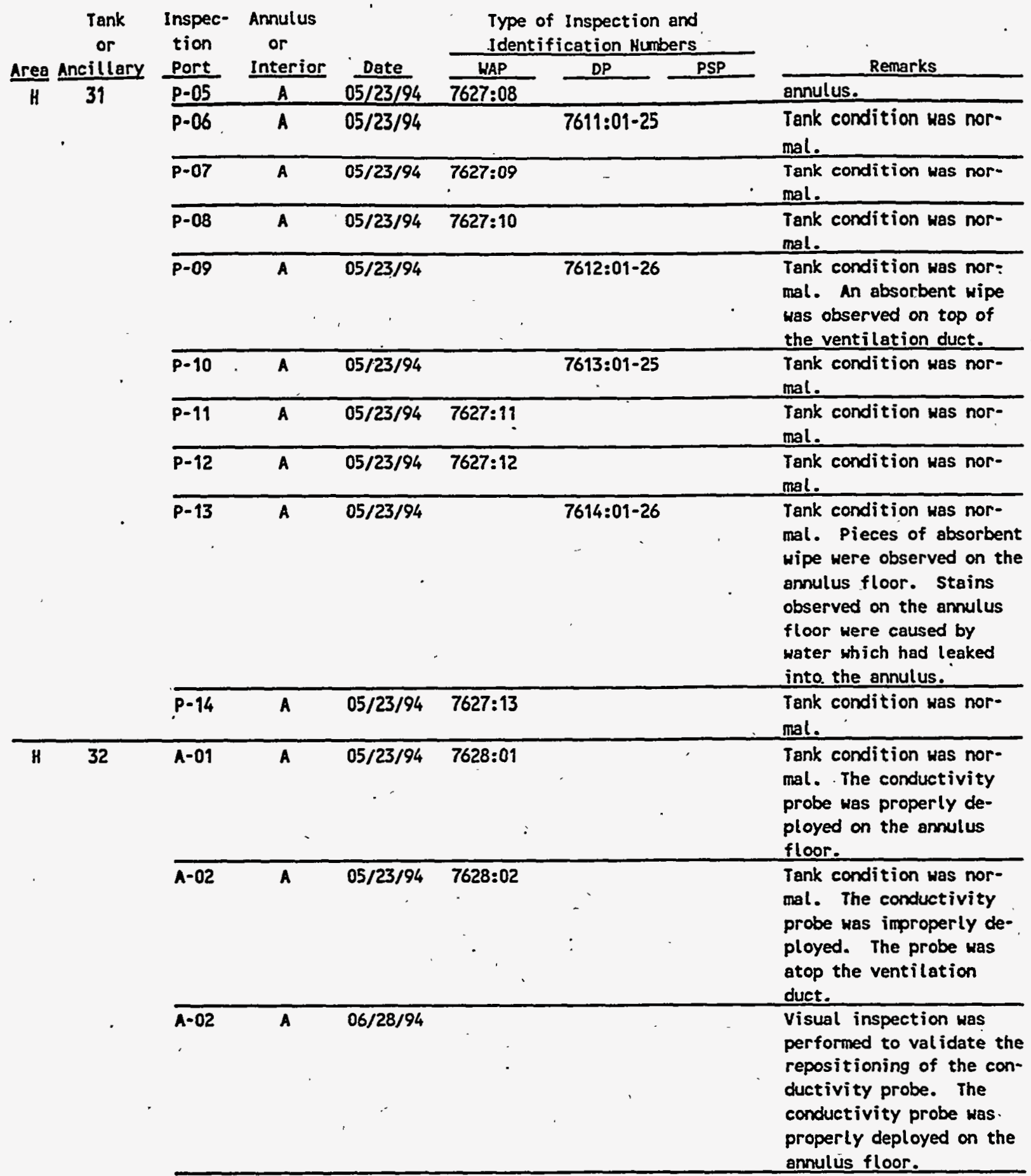




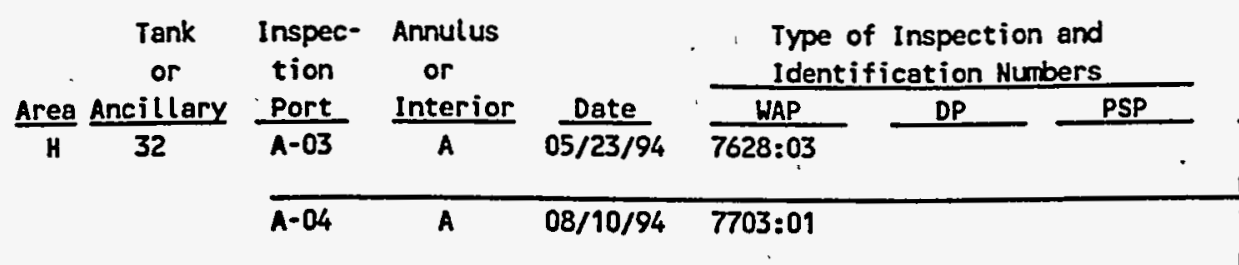
mal.

Tank condition was normal. The conductivity probe was properly deployed on the annulus floor. The magnetically mounted thermocouple was properly positioned on the tank' wall.

\begin{tabular}{lllll}
\hline P-01 & A & $08 / 10 / 94$ & $7703: 02$ & \\
\hline P-02 & A & $08 / 10 / 94$ & $7703: 03$ & \\
P-03 & A & $05 / 23 / 94$ & & $7615: 01-25$
\end{tabular}
-Tank condition was normal.

Tank condition was normal.

\begin{tabular}{llllll}
\hline P-03 & A & $05 / 23 / 94$ & & $7615: 01-25$ & $\begin{array}{l}\text { Tank condition was nor- } \\
\text { mal. }\end{array}$ \\
\hline P-04 & A & $05 / 23 / 94$ & $7628: 04$ & & $\begin{array}{l}\text { Tank condition was nor- } \\
\text { mal. }\end{array}$ \\
\hline P-05 & A & $05 / 23 / 94$ & $7628: 05$ & $\begin{array}{l}\text { Tank condition was nor- } \\
\text { mal. }\end{array}$ \\
\hline P-06 & A & $05 / 23 / 94$ & & $7616: 01-25$ & \begin{tabular}{l} 
Tank condition was nor- \\
\hline
\end{tabular}
\end{tabular}
mal. However, water had leaked into the annulus causing stains and water marks on the surface of the tank wall. A yellow plastic bag was observed on the annulus floor.

\begin{tabular}{|c|c|c|c|c|}
\hline$P-07$ & A & $05 / 23 / 94$ & $7628: 06$ & $\begin{array}{l}\text { Tank condition was nor- } \\
\text { mal. }\end{array}$ \\
\hline P-08 & $A$ & $05 / 23 / 94$ & $7628: 07$ & $\begin{array}{l}\text { Tank condition was nor- } \\
\text { mal. }\end{array}$ \\
\hline P-09 & $A$ & $05 / 23 / 94$ & $7617: 01-25$ & $\begin{array}{l}\text { Tank condition was nor- } \\
\text { mal. A socket with an } \\
\text { extension was observed on } \\
\text { the ventilation duct. }\end{array}$ \\
\hline$P-10$ & A & $05 / 23 / 94$ & $7618: 01-26$ & $\begin{array}{l}\text { Tank condition was nor- } \\
\text { mal. }\end{array}$ \\
\hline$p-11$ & A & $06 / 13 / 94$ & $7660: 01$ & $\begin{array}{l}\text { Tank condition was nor- } \\
\text { mal. }\end{array}$ \\
\hline$P-12$ & $A$ & $05 / 23 / 94$ & $7628: 08$ & $\begin{array}{l}\text { Tank condition was nor- } \\
\text { mal. }\end{array}$ \\
\hline$P-13$ & A & $05 / 23 / 94$ & 7628:09 & $\begin{array}{l}\text { Tank condition was nor- } \\
\text { mal. }\end{array}$ \\
\hline
\end{tabular}




\begin{tabular}{|c|c|c|c|c|c|c|c|}
\hline \multirow{2}{*}{ Ares } & \multirow{2}{*}{$\begin{array}{c}\text { Tank } \\
\text { or } \\
\text { Ancillary }\end{array}$} & \multirow{2}{*}{$\begin{array}{l}\text { Inspec- } \\
\text { tion } \\
\text { Port }\end{array}$} & \multirow{2}{*}{$\begin{array}{l}\text { Annulus } \\
\text { or } \\
\text { Interior }\end{array}$} & \multirow[b]{2}{*}{ Date } & \multicolumn{3}{|c|}{$\begin{array}{l}\text { Type of Inspection and } \\
\text { Identification Numbers }\end{array}$} \\
\hline & & & & & WAP & $D P$ & PSP \\
\hline H & 32 & $P-13$ & A & $05 / 23 / 94$ & & $7619: 01-25$ & \\
\hline & . & $p-14$ & A & $06 / 13 / 94$ & $7660: 02$ & & \\
\hline & & $p-15$ & A & $05 / 23 / 94$ & $7628: 10$ & & \\
\hline $\boldsymbol{F}$ & 33 & $A-01$ & A & $06 / 07 / 94$ & $7688: 01$ & & \\
\hline
\end{tabular}
mal.

Tank condition was normal. Tank condition was normal.

Tank condition was normal. Stains and marks observed on the ventilation duct were caused by water which had leaked into the annulus. The conductivity probe was properly deployed on the annulus floor.

A-02 A 06/07/94 7688:02 Tank condition was nor-
mal. Stains and marks observed on the ventilation duct were caused by water which had leaked into the annulus. The conductivity probe was properly deployed on the annulus floor.

\begin{tabular}{lllll}
\hline A-03 & A & $06 / 07 / 94$ & $7688: 03$ & $\begin{array}{l}\text { Tank condition was nor- } \\
\text { mal. }\end{array}$ \\
\hline A-04 & A & $06 / 07 / 94$ & $7688: 04$ & Tank condition was nor-
\end{tabular}
mal. An absorbent wipe was observed on the ventilation duct. The conductivity probe was properly deployed. on the annulus floor. The magnetically mounted thermocouple was located too high on the tank wall.

\begin{tabular}{lllll}
\hline P-01 & A & $06 / 07 / 94$ & $7688: 05$ & Tank \\
\hline P-02 & A & $06 / 07 / 94$ & $7688: 06$ & Tank
\end{tabular}
Tank condition was normal.

Tank condition was nor-. mal. An absorbent wipe was observed on the ventilation duct.

\begin{tabular}{llll}
\hline P-03 A & $06 / 09 / 94$ & $7661: 01-25$ & $\begin{array}{l}\text { Tank condition was nor- } \\
\text { mal. Approximately } 50\end{array}$ \\
& feet of small diameter \\
& tubing or electrical wire \\
& and an absorbent wipe was
\end{tabular}




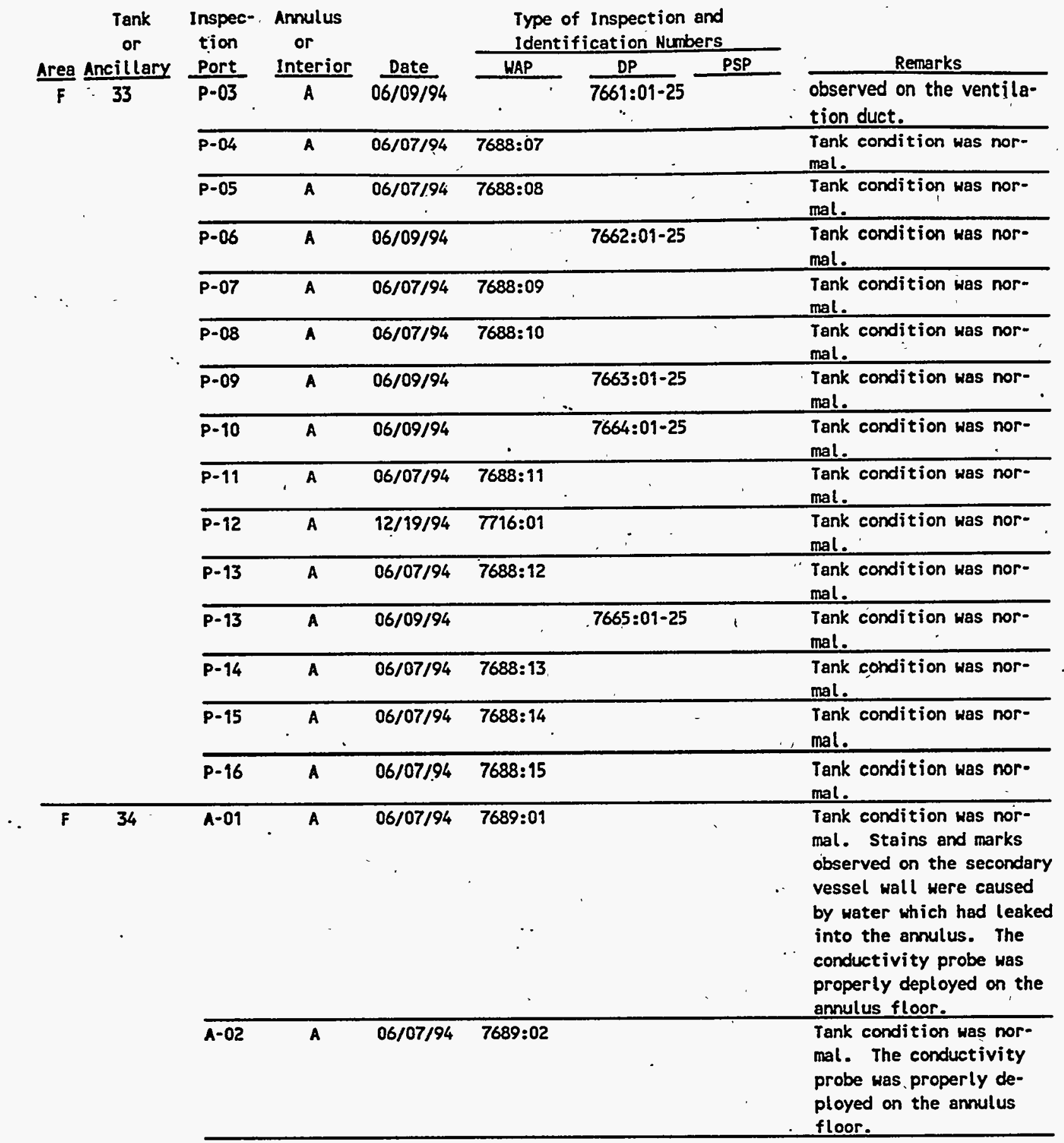




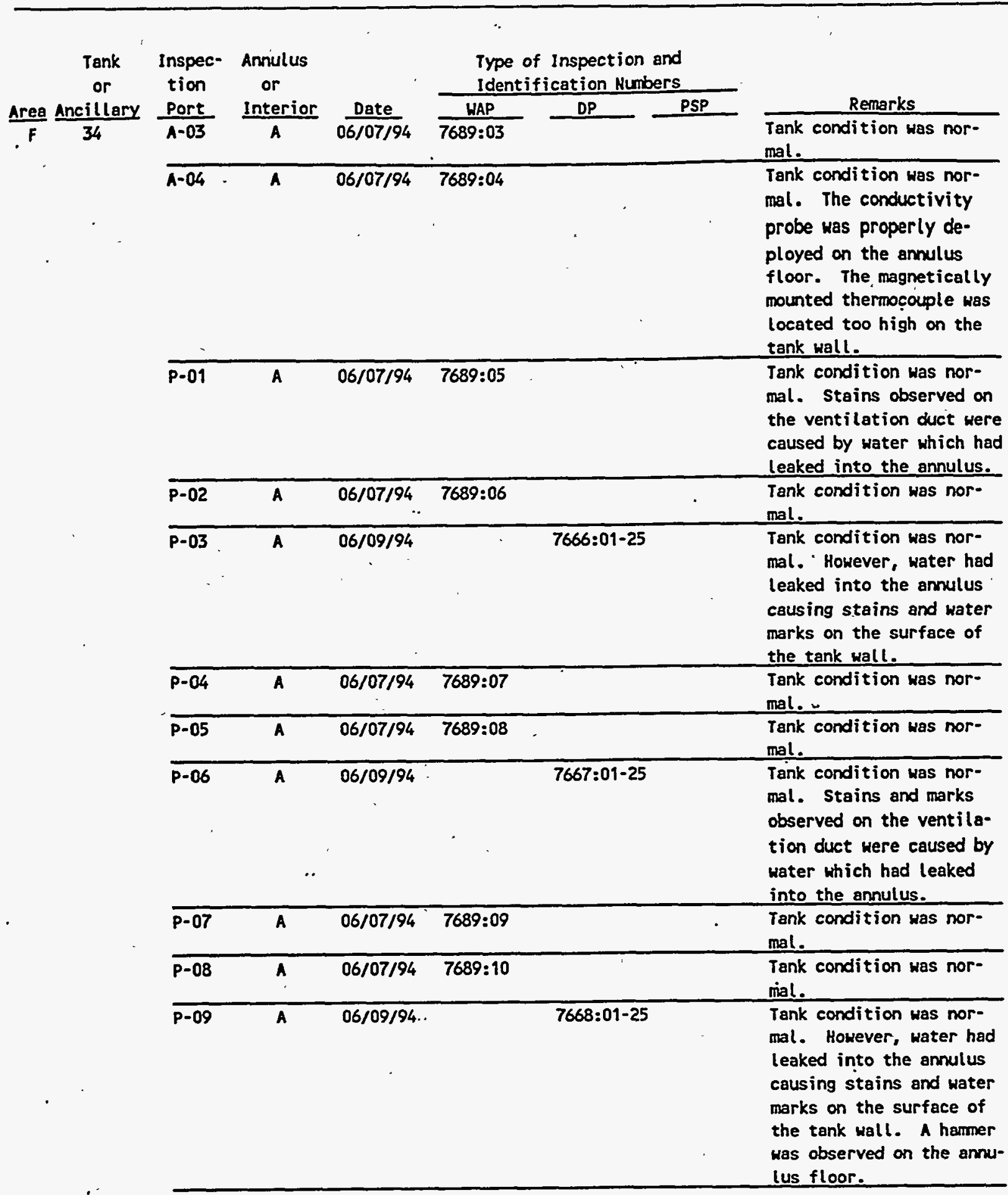




\begin{tabular}{|c|c|c|c|c|c|c|}
\hline \multirow{2}{*}{$\begin{array}{c}\begin{array}{c}\text { Tank } \\
\text { or } \\
\text { Area Ancillary }\end{array} \\
\end{array}$} & \multirow{2}{*}{$\begin{array}{c}\text { Inspec- } \\
\text { tion } \\
\text { Port } \\
\end{array}$} & \multirow{2}{*}{$\begin{array}{l}\text { Annulus } \\
\text { or } \\
\text { Interior }\end{array}$} & \multirow[b]{2}{*}{ Date } & \multicolumn{3}{|c|}{$\begin{array}{l}\text { Type of Inspection and } \\
\text { Identification Numbers }\end{array}$} \\
\hline & & & & WAP & DP & PSP \\
\hline$F \longdiv { 3 4 }$ & P-09 & A & $12 / 07 / 94$ & & & \\
\hline
\end{tabular}

CCTV was used to obtain closeup view of the object observed during a previous inspection made on 06-09-94. The object was $a$ ball peen harmer on the annulus floor. The inspection was documented on File Tape \#294.

\begin{tabular}{llll}
\hline$P-10$ & A & $06 / 09 / 94$ & $7669: 01-25$
\end{tabular}
Tank condition was normal. Stains observed on the tank wall were caused by water which hod leaked into the annulus.

\begin{tabular}{|c|c|c|c|}
\hline$p-11$ & $06 / 07 / 94$ & $7689: 11$ & $\begin{array}{l}\text { Tank condition wes nor- } \\
\text { mal. }\end{array}$ \\
\hline
\end{tabular}

\begin{tabular}{ccc}
\hline P-12 A & $06 / 07 / 94$ & $7689: 12$ \\
\hline
\end{tabular}
Tank condition was normal.

\begin{tabular}{llllll}
\hline P-13 & A & $06 / 09 / 94$ & & $7670: 01-25$ & $\begin{array}{l}\text { Tank condition was nor- } \\
\text { mal. }\end{array}$ \\
\hline P-14 & A & $06 / 07 / 94$ & $7689: 13$ & $\begin{array}{l}\text { Tank condition was nor- } \\
\text { mal. }\end{array}$ \\
\hline P-15 & A & $06 / 07 / 94$ & $7689: 14$ & $\begin{array}{l}\text { Tank condition was nor- } \\
\text { mal. }\end{array}$ \\
\hline P-16 & A & $06 / 07 / 94$ & $7689: 15$ & Tank condition was nor-
\end{tabular}

mal. Stains observed on the annulus floor were caused by water which had leaked into the annulus.

\begin{tabular}{llllll}
\hline H & 35 & A-01 & A & $-05 / 24 / 94$ & $7591: 01-26$
\end{tabular}
Tank condition was normal. However, water had leaked into the annulus causing stains and water marks on the surface of the tank wall.

\begin{tabular}{lll}
\hline $1-02 \quad$ A & 05/24/94 & $7592: 01-26$
\end{tabular}
Tank condition was normal. However, water had leaked into the annulus causing stains and water marks on the surface of the tank wall. The conductivity probe was properly deployed on the annulus floor. 


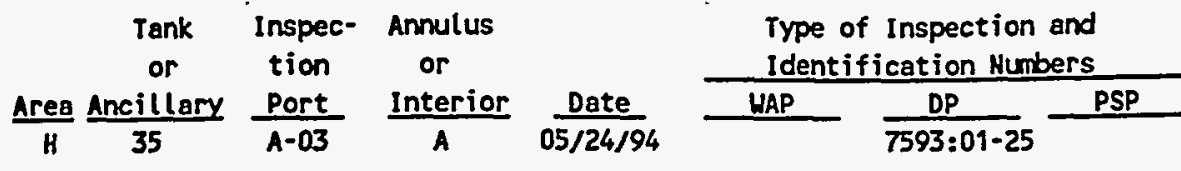

Remarks

Tank condition was normal. However, water had leaked into, the annulus causing stains and.water marks on the surface of the tank wall. The conductivity probe was properly'deployed on the annulus floor.

\begin{tabular}{llll}
\hline$A-04$ & $A$ & $05 / 24 / 94$ & $7594: 01-25$
\end{tabular}

Tank condition was normal. However, water had leaked into the annulus causing stains and water marks on the surface of the tank wall. The conductivity probe was properly deployed on the annulus floor.

\begin{tabular}{llllll}
\hline P-01 & A & 05/24/94 & $7588: 14$ & $\begin{array}{l}\text { Tank condition was nor- } \\
\text { mal. }\end{array}$ \\
\hline P-02 & A & $05 / 24 / 94$ & $7588: 13$ & $\begin{array}{l}\text { Tank condition was nor- } \\
\text { mal. }\end{array}$ \\
\hline P-03 & A & $05 / 24 / 94$ & $7588: 06$ & $\begin{array}{l}\text { Tank condition was nor- } \\
\text { mal. }\end{array}$ \\
\hline P-04 & A & $05 / 24 / 94$ & $7588: 05$ & $\begin{array}{l}\text { Tank condition was nor- } \\
\text { mal. }\end{array}$ \\
\hline P-05 & A & $05 / 24 / 94$ & $7588: 04$ & $\begin{array}{l}\text { Tank condition was nor- } \\
\text { mal. Stains observed on }\end{array}$
\end{tabular}
the secondary wall were caused by water which had leaked into the annulus. Tank condition was normal.

Tank condition was normal. Stains observed on the secondary wall were caused by water which had leaked into the annulus. . Tank condition was normal.

\begin{tabular}{llllll}
\hline P-08 & A & $05 / 24 / 94$ & $7588: 09$ & & $\begin{array}{l}\text { Tank condition was nor- } \\
\text { mal. }\end{array}$ \\
\hline P-09 & A & $05 / 24 / 94$ & $7588: 08$ & & $\begin{array}{l}\text { Tank condition was nor- } \\
\text { mal. Stains observed on } \\
\text { the secondary wall were } \\
\text { caused by water which had } \\
\text { leaked into the annulus. }\end{array}$ \\
\hline
\end{tabular}




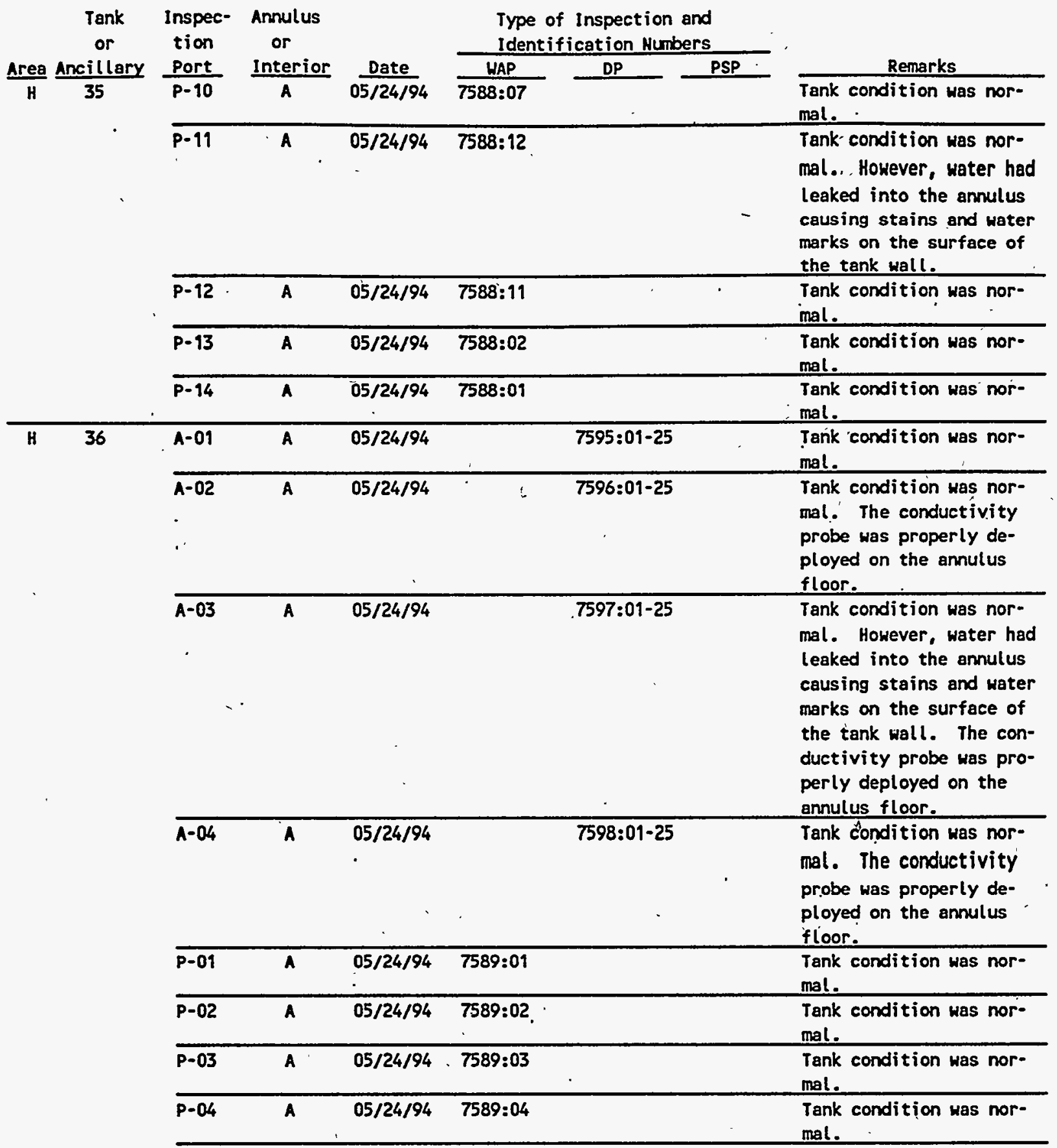




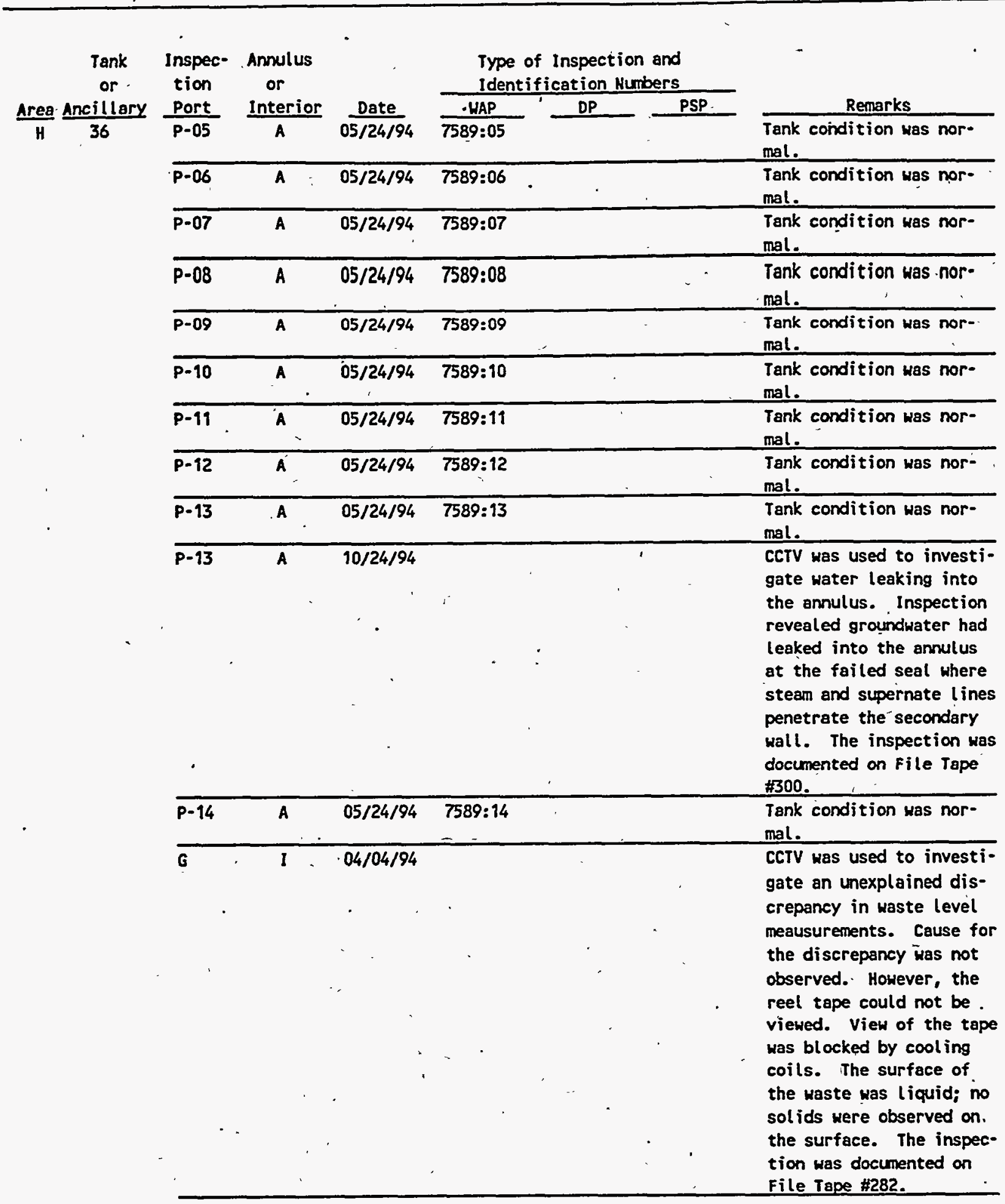




\begin{tabular}{|c|c|c|c|c|c|c|}
\hline \multirow{3}{*}{ 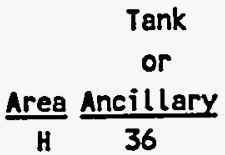 } & \multirow{2}{*}{$\begin{array}{c}\text { Inspec- } \\
\text { tion } \\
\text { Port } \\
\end{array}$} & \multirow{2}{*}{$\begin{array}{l}\text { Annulus } \\
\text { or } \\
\text { Interior }\end{array}$} & \multirow[b]{2}{*}{ Date } & \multicolumn{3}{|c|}{$\begin{array}{l}\text { Type of Inspection and } \\
\text { Identification Numbers }\end{array}$} \\
\hline & & & & HAP & DP & PSP \\
\hline & $\mathrm{H}$ & $I$ & $\overline{04 / 04 / 94}$ & & & \\
\hline
\end{tabular}

CCIV was used to invest $i-$ gate an unexplained discrepancy in waste level measurements. Cause for the discrepancy was not. observed. However, the reel tape could not be viewed. Vien of the tape was blocked by cooling coils. The surface of the waste was liquid; no solids were observed on the surface. The inspection was documented on File Tape \#282.

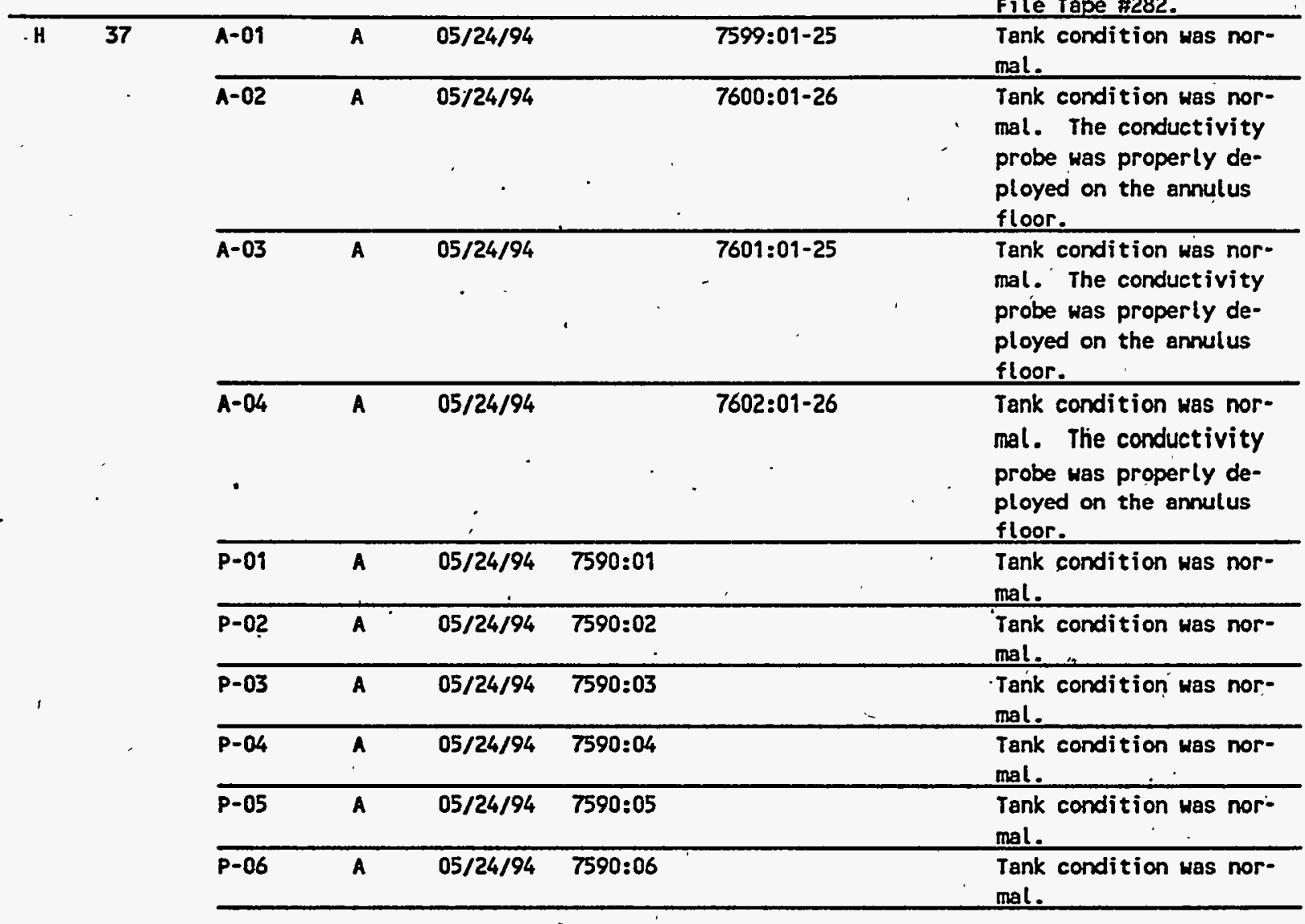




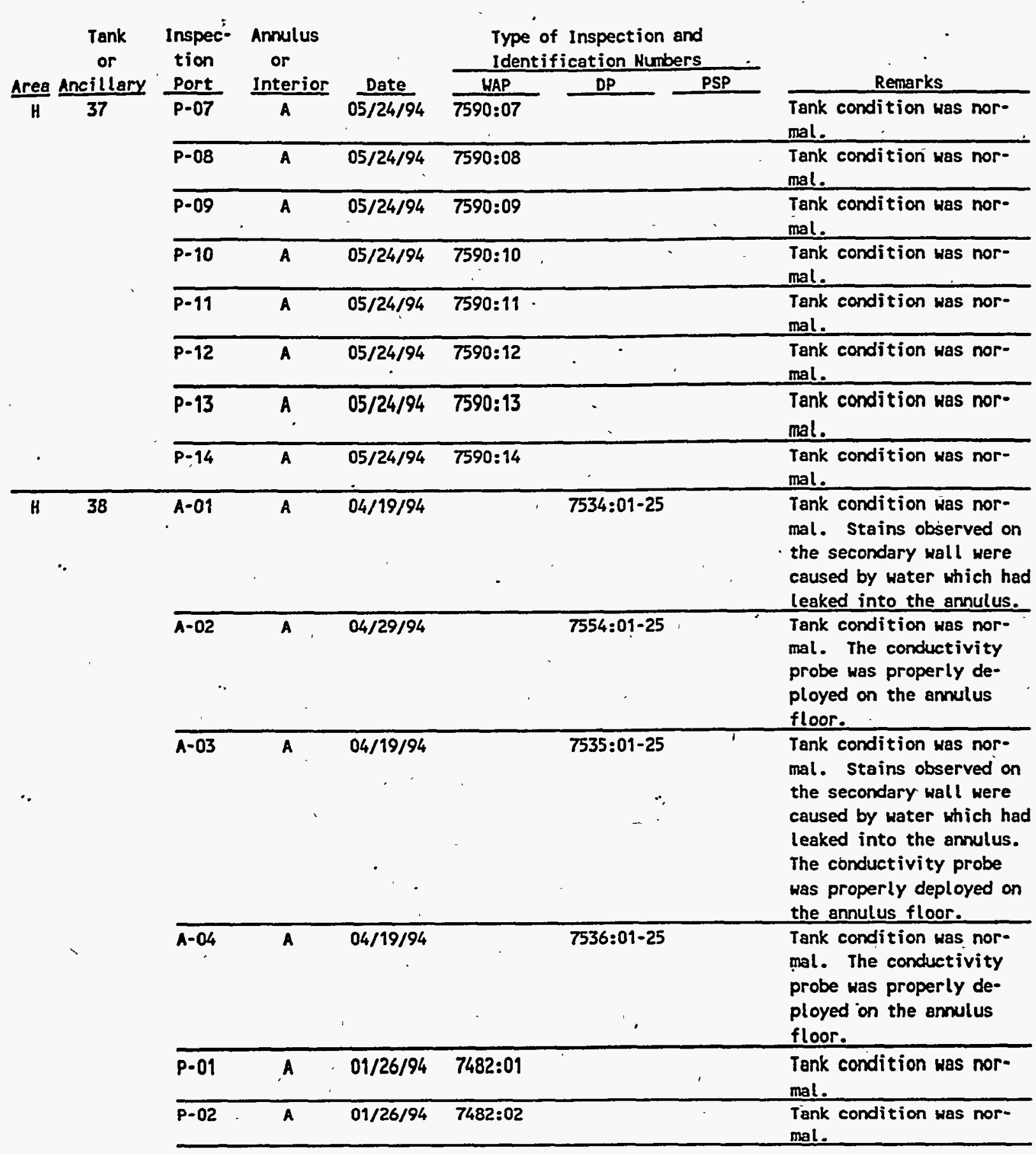




\begin{tabular}{|c|c|c|c|c|c|c|c|c|}
\hline \multirow{2}{*}{ Area } & \multirow{2}{*}{$\begin{array}{c}\text { Tank } \\
\text { or } \\
\text { Ancillary }\end{array}$} & \multirow{2}{*}{$\begin{array}{c}\text { Inspec- } \\
\text { tion } \\
\text { Port } \\
\end{array}$} & \multirow{2}{*}{$\begin{array}{l}\text { Annulus } \\
\text { or. } \\
\text { Interior }\end{array}$} & \multirow[b]{2}{*}{ Date } & \multicolumn{3}{|c|}{$\begin{array}{l}\text { Type of Inspection and } \\
\text { Identification Numbers }\end{array}$} & \multirow[b]{2}{*}{ Remarks } \\
\hline & & & & & WAP & $D P$ & PSP & \\
\hline & 38 & $P-03$ & A & $01 / 26 / 94$ & $7482: 03$ & & & $\begin{array}{l}\text { Tank condition was nor- } \\
\text { mal. }\end{array}$ \\
\hline & & P-04 & A & $01 / 26 / 94$ & $7482: 04$ & & & $\begin{array}{l}\text { Tank condition was nor- } \\
\text { mal. }\end{array}$ \\
\hline & & $p-05$ & A & $01 / 26 / 94$ & $7482: 05$ & & & $\begin{array}{l}\text { Tank condition was nor- } \\
\text { mal. }\end{array}$ \\
\hline & & $\overline{p-06}$ & A & $01 / 26 / 94$ & $7482: 06$ & & & $\begin{array}{l}\text { Tank condition was nor- } \\
\text { mal. }\end{array}$ \\
\hline & & $P-07$ & A & $01 / 26 / 94$ & $7482: 07$ & & & $\begin{array}{l}\text { Tank condition was nor- } \\
\text { mal. }\end{array}$ \\
\hline & & p. 08 & A & $01 / 26 / 94$ & $7482: 08$ & & & $\begin{array}{l}\text { Tank condition was nor- } \\
\text { mal. }\end{array}$ \\
\hline & . & P-09 & A & $01 / 26 / 94$ & $7482: 09$ & & & $\begin{array}{l}\text { Tank condition was nor- } \\
\text { mal. }\end{array}$ \\
\hline & & $P-10$ & A & $01 / 26 / 94$ & $7482: 10$ & & & $\begin{array}{l}\text { Tank condition was nor- } \\
\text { mal. }\end{array}$ \\
\hline & & $p-11$ & A & $01 / 26 / 94$ & $7482: 11$ & & & $\begin{array}{l}\text { Tank condition was nor- } \\
\text { mal. }\end{array}$ \\
\hline & & $p-12$ & A & $01 / 26 / 94$ & $7482: 12$ & & & $\begin{array}{l}\text { Tank condition was nor- } \\
\text { mal. }\end{array}$ \\
\hline & & $P-13$ & A & $01 / 26 / 94$ & $7482: 13$ & & & $\begin{array}{l}\text { Tank condition was nor- } \\
\text { mal. }\end{array}$ \\
\hline & & $P-14$ & A & $01 / 26 / 94$ & $7482: 14$ & & & $\begin{array}{l}\text { Tank condition was nor- } \\
\text { mal. }\end{array}$ \\
\hline & & $c-01$ & $I$ & $09 / 26 / 94$ & & & - & $\begin{array}{l}\text { CCTV inspection was made } \\
\text { to check the downcomer } \\
\text { configuration in the C-1 } \\
\text { riser. Inspection re- } \\
\text { vealed no downcomer; how- } \\
\text { ever, a deflector was in- } \\
\text { stalled. The inspection } \\
\text { was documented on File } \\
\text { Tape \#297. }\end{array}$ \\
\hline$\cdot$ & & $c-01$ & $I$ & $12 / 03 / 94$ & V & $\cdot$ & . & $\begin{array}{l}\text { CCTV was used to provide } \\
\text { for remote rotation and } \\
\text { leak check of the trans- } \\
\text { fer jet. After the ini- } \\
\text { tial leak check failed, } \\
\text { cam locks and connector } \\
\text { heads were regasketed and } \\
\text { tightened. The subse- } \\
\text { quent leak check verified } \\
\text { tightness. The inspec- } \\
\text { tion was documented on } \\
\text { File Tape } \$ 302 \text {. }\end{array}$ \\
\hline
\end{tabular}




\begin{tabular}{|c|c|c|c|c|c|c|}
\hline $\begin{array}{l}\text { Tank } \\
\text { or }\end{array}$ & $\begin{array}{l}\text { Inspec- } \\
\text { tion }\end{array}$ & $\begin{array}{l}\text { Annulus } \\
\text { or }\end{array}$ & & & & \\
\hline rea Ancil lary & Port & Interior & Date & WAP & DP & PSP \\
\hline
\end{tabular}

Remarks

CCTV was used to provide for remote rotation and leak check of the transfer jet. No leakage was observed during the leak check. The inspection was documented on File Tape \$308.

H I $\quad 12 / 15 / 94$

\begin{tabular}{llllll}
\hline$H$ & 39 & $A-01$ & A & $04 / 18 / 94$ & $7533: 01-25$ \\
\cline { 3 - 5 } & A-02 & A & $04 / 18 / 94$ & $7532: 01-25$
\end{tabular}

CCTV was used to investigate and document salt quantity and configuration in the tank. Ho salt build-up was observed on the cooling coils or the tank wall. The waste surface appeared to be uniform throughout the. tank. The inspection was documented on File Tape \#307.

Tank condition was nor$\mathrm{mal}$.

Tank condition was normal. The conductivity probe was properly deployed on the annulus floor.

\begin{tabular}{llll}
\hline A-03 A & $04 / 18 / 94$ & $7531: 01-25$ & Tank condition was nor- \\
& mal. The conductivity
\end{tabular}
probe was properly deployed on the annulus floor.

\begin{tabular}{lll}
\hline-04 & $04 / 18 / 94$ & $7530: 01-25$
\end{tabular}

Tank condition was normal. The conductivity probe was properly deployed on the annulus floor.

\begin{tabular}{llllll}
\hline P-01 & A & $05 / 26 / 94$ & $7629: 01$ & $\begin{array}{l}\text { Tank condition was nor } \\
\text { mal. }\end{array}$ \\
\hline P-02 & A & $05 / 26 / 94$ & $7629: 02$ & $\begin{array}{l}\text { Tank condition was nor- } \\
\text { mal. }\end{array}$ \\
\hline P-03 & A & $05 / 26 / 94$ & $7629: 03$ & $\begin{array}{l}\text { Tank condition was nor- } \\
\text { mal. }\end{array}$ \\
\hline
\end{tabular}




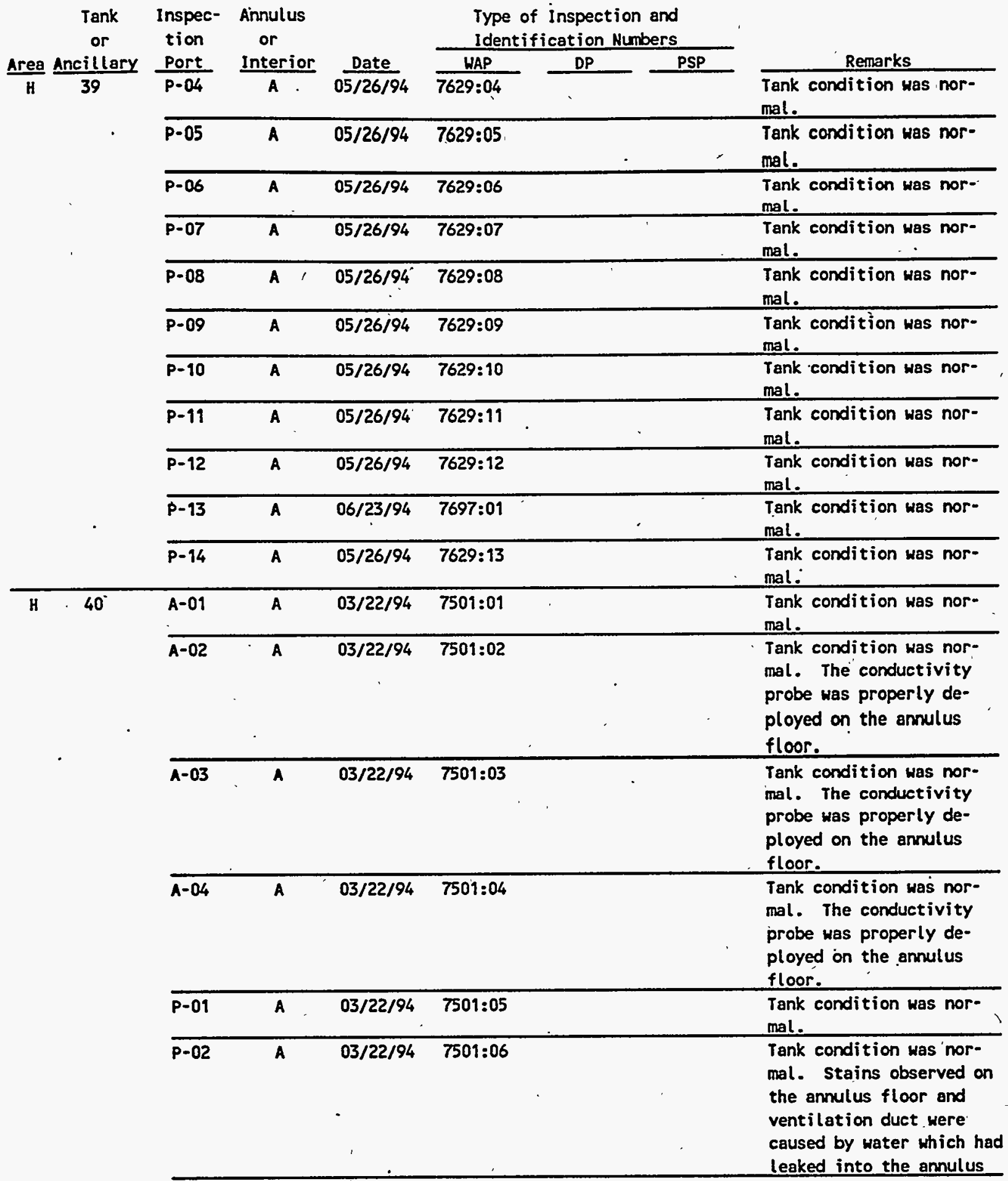




\begin{tabular}{|c|c|c|c|c|c|c|c|c|}
\hline \multirow{15}{*}{$\frac{\text { Area }}{H}$} & \multirow{3}{*}{$\begin{array}{c}\begin{array}{c}\text { Tank } \\
\text { or } \\
\text { Ancillary }\end{array} \\
\frac{40}{4}\end{array}$} & \multirow{2}{*}{$\begin{array}{l}\text { Inspec- } \\
\text { tion } \\
\text { Port }\end{array}$} & \multirow{2}{*}{$\begin{array}{l}\text { Annulus } \\
\text { or } \\
\text { Interior }\end{array}$} & \multirow[b]{2}{*}{ Date } & \multicolumn{3}{|c|}{$\begin{array}{l}\text { Type of Inspection and } \\
\text { Identification Numbers }\end{array}$} & \multirow[b]{2}{*}{ Remarks } \\
\hline & & & & & HAP & $D P$ & PSP & \\
\hline & & $\mathrm{P}-02$ & A & $03 / 22 / 94$ & $7501: 06$ & & & via the riser plug. \\
\hline & & p-03 & $A$ & $03 / 22 / 94$ & $7501: 07$ & & & $\begin{array}{l}\text { Tank condition was nor- } \\
\text { mal. }\end{array}$ \\
\hline & - & $\mathrm{p}-04$ & $A$ & $03 / 22 / 94$ & $7501: 08$ & . & & $\begin{array}{l}\text { Tank condition was nor- } \\
\text { mal. }\end{array}$ \\
\hline & . & $p-05$ & A & $04 / 06 / 94$ & & $7520: 01-25$ & & $\begin{array}{l}\text { Tank condition was nor-. } \\
\text { mal. }\end{array}$ \\
\hline & & $p-06$ & A & $03 / 22 / 94$ & $7501: 09$ & - & $\cdot \cdot$ & $\begin{array}{l}\text { Tank condition was nor- } \\
\text { mal. }\end{array}$ \\
\hline & , & $p-07$ & A & $03 / 22 / 94$ & $7501: 10$ & & & $\begin{array}{l}\text { Tank condition was nor- } \\
\text { mal. }\end{array}$ \\
\hline & & $p-08$ & A & $04 / 06 / 94$ & & $7519: 01-25$ & & $\begin{array}{l}\text { Tank condition was nor- } \\
\text { mal. }\end{array}$ \\
\hline & & p-09 & A & $03 / 22 / 94$ & $7501: 11$ & & • & $\begin{array}{l}\text { Tank condition was nor- } \\
\mathrm{mal} \text {. }\end{array}$ \\
\hline & & $p-10$ & A & $03 / 22 / 94$ & $7501: 12$ & & & $\begin{array}{l}\text { Tank condition was nor- } \\
\mathrm{mal} \text {. }\end{array}$ \\
\hline & & $P-11$ & A & $04 / 06 / 94$ & & $7515: 01-25$ & & $\begin{array}{l}\text { Tank condition was nor- } \\
\text { mal. }\end{array}$ \\
\hline & & $p-12$ & A & $03 / 22 / 94$ & $7501: 13$ & $\cdot$ & & $\begin{array}{l}\text { Tank condition was nor- } \\
\text { mal. }\end{array}$ \\
\hline & & $p-13$ & A & $03 / 22 / 94$ & $7501: 14$ & $\cdot$ & & $\begin{array}{l}\text { Tank condition was nor- } \\
\text { mal. }\end{array}$ \\
\hline & & $p-14$ & A & $05 / 02 / 94$ & & $7569: 01-25$ & & $\begin{array}{l}\text { Tank condition was nor- } \\
\text { mal. }\end{array}$ \\
\hline H & 41 & $A-01$ & A & $04 / 20 / 94$ & .. & $7540: 01-25$ & & $\begin{array}{l}\text { Tank condition was nor- } \\
\text { mal. }\end{array}$ \\
\hline & & $A-02$ & A & $04 / 20 / 94$ & & $7541: 01-25$ & & $\begin{array}{l}\text { Tank condition was nor- } \\
\text { mal. }\end{array}$ \\
\hline & & $A-02$ & A & $05 / 26 / 94$ & & 1 & & $\begin{array}{l}\text { Visual inspection reveal- } \\
\text { ed the conductivity probe } \\
\text { was properly deployed on } \\
\text { the annulus floor. }\end{array}$ \\
\hline & & A.03 & A & $04 / 20 / 94$ & & $7542: 01-25$ & & $\begin{array}{l}\text { Tank condition was nor- } \\
\text { mal. The conductivity } \\
\text { probe was properly de- } \\
\text { ployed on the annulus } \\
\text { floor. }\end{array}$ \\
\hline ' & . & $A-04$ & $A$ & $04 / 20 / 94$ & & $7543: 01-26$ & $\therefore$ & $\begin{array}{l}\text { Tank condition was nor- } \\
\text { mal. The conductivity } \\
\text { probe was properly de- } \\
\text { ployed on the annulus } \\
\text { floor. }\end{array}$ \\
\hline
\end{tabular}




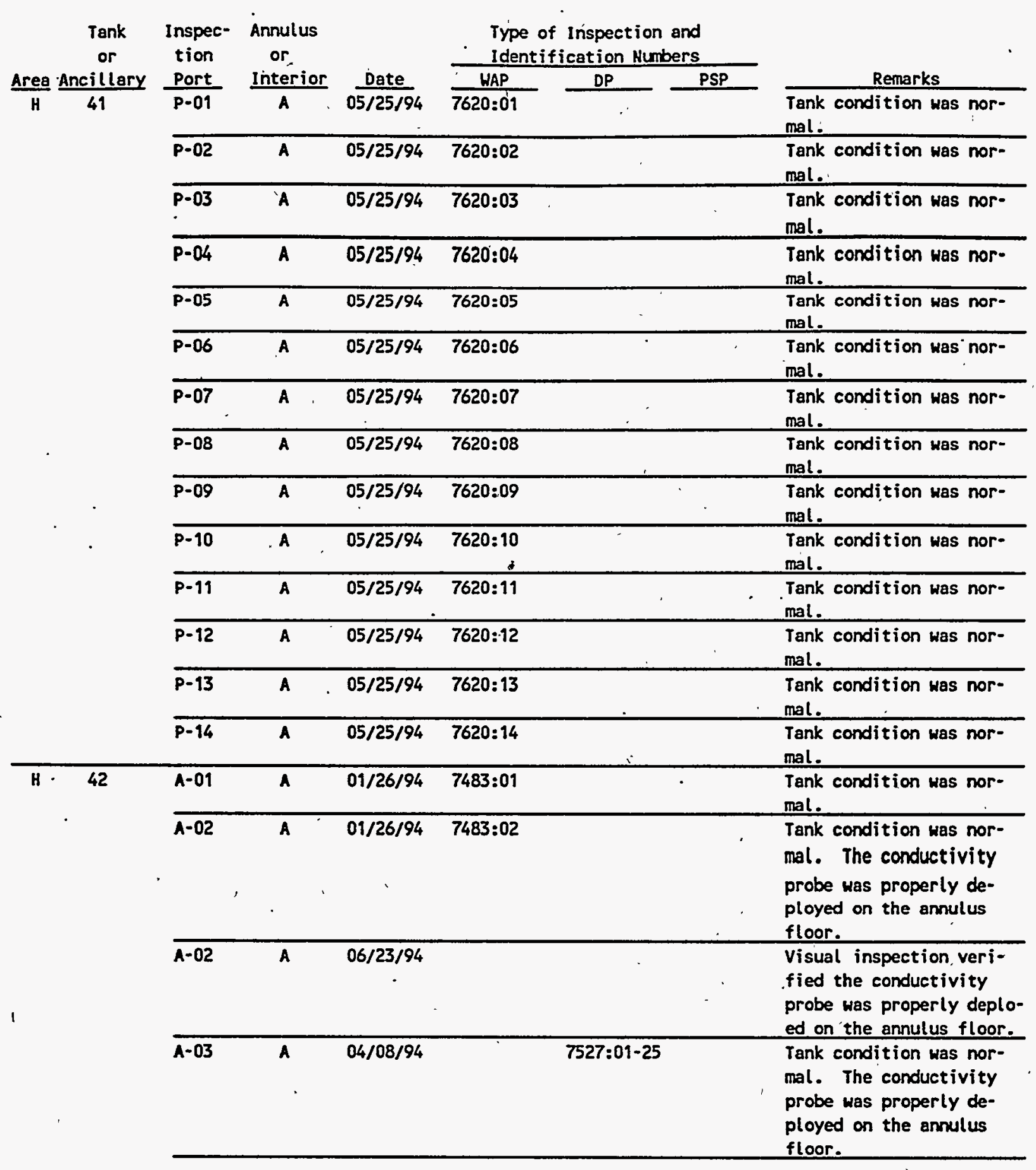




\begin{tabular}{|c|c|c|c|c|c|c|c|c|}
\hline \multirow{2}{*}{ Area } & \multirow{2}{*}{$\begin{array}{c}\text { Tank } \\
\text { or } \\
\text { Ancillary }\end{array}$} & \multirow{2}{*}{$\begin{array}{l}\text { Inspec- } \\
\text { tion } \\
\text { Port } \\
\end{array}$} & \multirow{2}{*}{$\begin{array}{l}\text { Annulus } \\
\text { or } \\
\text { Interior }\end{array}$} & \multirow[b]{2}{*}{ Date } & \multicolumn{3}{|c|}{$\begin{array}{l}\text { Type of Inspection and } \\
\text { Identification Numbers }\end{array}$} & \multirow[b]{2}{*}{ Remarks } \\
\hline & & & & & HAP & $\mathrm{DP}$ & PSP & \\
\hline \multirow[t]{16}{*}{ H } & 42 & $A-04$ & A & $01 / 26 / 94$ & $7483: 03$ & - & $\cdot$ & $\begin{array}{l}\text { Tank condition was nor- } \\
\text { mal. The conductivity } \\
\text { probe was properly de- } \\
\text { ployed on the annulus } \\
\text { floor. }\end{array}$ \\
\hline & & $A-04$ & A & $06 / 23 / 94$ & & - & - & $\begin{array}{l}\text { Visual inspection verifi- } \\
\text { ed the conductivity probe } \\
\text { was properly deployed on } \\
\text { the annulus floor. }\end{array}$ \\
\hline & & $p-01$ & A & $01 / 26 / 94$ & 7483:04 & . & & $\begin{array}{l}\text { Tank condition was nor- } \\
\text { mal. }\end{array}$ \\
\hline & : & p-02 & A & $01 / 26 / 94$ & $7483: 05^{\circ}$ & & & $\begin{array}{l}\text { Tank condition was nor- } \\
\text { mal. }\end{array}$ \\
\hline & & $P-03$ & A & $04 / 29 / 94$ & - & $7553: 01-25$ & & $\begin{array}{l}\text { Tank condition was nor- } \\
\text { mal. }\end{array}$ \\
\hline & & P-04 & A & $01 / 26 / 94$ & 7483:06 & & & $\begin{array}{l}\text { Tank condition was nor- } \\
\text { mal. }\end{array}$ \\
\hline & & P-05 & A & $01 / 26 / 94$ & 7483:07 & & & $\begin{array}{l}\text { Tank condition was nor- } \\
\text { mal. }\end{array}$ \\
\hline & & P- 06 & A & $\begin{array}{c}01 / 26 / 94 \\
. \\
\end{array}$ & $7483: 08$ & & & $\begin{array}{l}\text { Tank condition was nor- } \\
\text { mal. }\end{array}$ \\
\hline & & $P-07$ & A & $04 / 06 / 94$ & & $7524: 01-25$ & & $\begin{array}{l}\text { Tank condition was nor: } \\
\text { mal. }\end{array}$ \\
\hline & & $P=08$ & A & $01 / 26 / 94$ & $7483: 09$ & & & $\begin{array}{l}\text { Tank condition was nor- } \\
\text { mal. }\end{array}$ \\
\hline & & P-09 & $A$ & $01 / 26 / 94$ & $\begin{array}{c}7483: 10 \\
-\end{array}$ & & & $\begin{array}{l}\text { Tank condition was nor- } \\
\text { mal. }\end{array}$ \\
\hline & & $P-10$ & A & $01 / 26 / 94$ & $7483=11$ & & & $\begin{array}{l}\text { Tank condition was nor- } \\
\text { mal. }\end{array}$ \\
\hline & & P-11 & $A$ & $04 / 06 / 94$ & & $7525=01-25$ & & $\begin{array}{l}\text { Tank condition was nor- } \\
\text { mal. }\end{array}$ \\
\hline & & $\begin{array}{r}\mathrm{P}-12 \\
\end{array}$ & $A$ & $01 / 26 / 94$ & $7483: 12$ & & . & $\begin{array}{l}\text { Tank condition was nor- } \\
\text { mal. }\end{array}$ \\
\hline & & $p-13$ & $\boldsymbol{A}$ & $01 / 26 / 94$ & $7483: 13$ & & & $\begin{array}{l}\text { Tank condition was nor- } \\
\text { mal. }\end{array}$ \\
\hline & " & $p-14$ & A & $01 / 26 / 94$ & $7483: 14$ & & & $\begin{array}{l}\text { Tank condition was nor- } \\
\text { mal. }\end{array}$ \\
\hline \multirow[t]{2}{*}{ H } & 43 & $A-01$ & A & $04 / 19 / 94$ & & $7537: 01-25$ & & $\begin{array}{l}\text { Tank condition wes nor- } \\
\text { mal. }\end{array}$ \\
\hline & $\cdot$ & $A-02$ & A & $04 / 19 / 94$ & & $7538: 01-25$ & & $\begin{array}{l}\text { Tank condition was nor- } \\
\text { mal. A short piece (a- } \\
\text { bout 2-3 feet) of green } \\
\text { tape was observed on the } \\
\text { annulus floor. The con- } \\
\text { ductivity probe was pro- } \\
\text { perly deployed on the } \\
\text { annulus floor. }\end{array}$ \\
\hline
\end{tabular}




\begin{tabular}{|c|c|c|c|c|c|c|c|c|}
\hline \multirow{2}{*}{ Area } & \multirow{2}{*}{$\begin{array}{c}\text { Tank } \\
\text { or } \\
\text { Ancillary } \\
\end{array}$} & \multirow{2}{*}{$\begin{array}{c}\text { Inspec- } \\
\text { tion } \\
\text { Port } \\
\end{array}$} & \multirow{2}{*}{$\begin{array}{l}\text { Annulus } \\
\text { or } \\
\text { Interior }\end{array}$} & \multirow[b]{2}{*}{ Date } & \multicolumn{3}{|c|}{$\begin{array}{l}\text { Type of Inspection and } \\
\text { Identification Numbers }\end{array}$} & \multirow{2}{*}{ Remarks } \\
\hline & & & & & UAP & $\mathrm{DP}$ & PSP & \\
\hline$H$ & 43 & $A-03$ & A & $04 / 29 / 94$ & & $7555: 01-25$ & & $\begin{array}{l}\text { Tank condition was nor- } \\
\text { mal. . }\end{array}$ \\
\hline & & A-04 & A & $04 / 19 / 94$ & . & $7539: 01-25$ & & $\begin{array}{l}\text { Tank condition was nor- } \\
\text { mal. A sheet of clear } \\
\text { plastic was observed on } \\
\text { the annulus floor. The } \\
\text { conductivity probe was } \\
\text { properly deployed on the } \\
\text { annulus floor. }\end{array}$ \\
\hline & . & $\overline{p-01}$ & A & $05 / 26 / 94$ & $7630: 01$ & & & $\begin{array}{l}\text { Tank condition was nor- } \\
\text { mal. }\end{array}$ \\
\hline & & $p-02$ & A & $05 / 26 / 94$ & $7630: 02$ & . & & $\begin{array}{l}\text { Tank condition was nor- } \\
\text { mal. }\end{array}$ \\
\hline & & $P-03$ & A & $06 / 13 / 94$ & $7659: 01$ & & & $\begin{array}{l}\text { Tank condition was nor- } \\
\text { mal. Stains observed on } \\
\text { the annulus floor were } \\
\text { caused by water which had } \\
\text { leaked into the annulus. }\end{array}$ \\
\hline & & $P-04$ & A & $05 / 26 / 94$ & $7630: 03$ & & & $\begin{array}{l}\text { Tank condition was nor- } \\
\text { mal. }\end{array}$ \\
\hline & & $P-05$ & A & $05 / 26 / 94$ & $7630: 04$ & ' & & $\begin{array}{l}\text { Tank condition was nor- } \\
\text { mal. }\end{array}$ \\
\hline & - & $P-06$ & A & $05 / 26 / 94$ & $7630: 05$ & & & $\begin{array}{l}\text { Tank condition was nor- } \\
\text { mal. }\end{array}$ \\
\hline & & $P-07$ & A & $05 / 26 / 94$ & $7630: 06$ & & & $\begin{array}{l}\text { Tank condition was nor- } \\
\text { mal. }\end{array}$ \\
\hline & & $P-08$ & A & $05 / 26 / 94$ & $7630: 07$ & & . & $\begin{array}{l}\text { Tank condition was nor- } \\
\text { mal. }\end{array}$ \\
\hline & & $P-09$ & A & $05 / 26 / 94$ & $7630: 08$ & & & $\begin{array}{l}\text { Tank condition was nor- } \\
\text { mal. }\end{array}$ \\
\hline & & $p-10$ & A & $05 / 26 / 94$ & $7630: 09$ & & & $\begin{array}{l}\text { Tank condition was nor- } \\
\text { mal. }\end{array}$ \\
\hline & & $P-11$ & A & $05 / 26 / 94$ & $7630: 10$ & & & $\begin{array}{l}\text { Tank condition was nor- } \\
\text { mal. }\end{array}$ \\
\hline & & $p-12$ & A & $05 / 26 / 94$ & $.7630: 11$ & & & $\begin{array}{l}\text { Tank condition was nor- } \\
\text { mal. }\end{array}$ \\
\hline & & $p-13$ & A & $05 / 26 / 94$ & $7630: 12$ & . & ? & $\begin{array}{l}\text { Tank condition was nor- } \\
\text { mal. }\end{array}$ \\
\hline & & P-14 & A & $05 / 26 / 94$ & $7630: 13$ & & & $\begin{array}{l}\text { Tank condition was nor- } \\
\text { mal. }\end{array}$ \\
\hline $\mathbf{F}$ & 44 & $A-01$ & A & $04 / 07 / 94$ & $7517: 09$ & & . & $\begin{array}{l}\text { Tank condition was nor- } \\
\text { mal. }\end{array}$ \\
\hline & & $A-02$ & A & $04 / 07 / 94$ & $7517: 02$ & & & $\begin{array}{l}\text { Tank condition was nor- } \\
\text { mal. The conductivity } \\
\text { probe was properly de- } \\
\text { ployed on the annulus } \\
\text { floor. }\end{array}$ \\
\hline
\end{tabular}




\begin{tabular}{|c|c|c|c|c|c|c|}
\hline \multirow{2}{*}{$\begin{array}{c}\begin{array}{c}\text { Tank } \\
\text { or } \\
\text { Area Ancillary }\end{array} \\
\end{array}$} & \multirow{2}{*}{$\begin{array}{l}\text { Inspec- } \\
\text { tion } \\
\text { Port }\end{array}$} & \multirow{2}{*}{$\begin{array}{l}\text { Annulus } \\
\text { or } \\
\text { Interior }\end{array}$} & \multirow[b]{2}{*}{ Date } & \multicolumn{3}{|c|}{$\begin{array}{l}\text { Type of Inspection and } \\
\text { Identification Numbers }\end{array}$} \\
\hline & & & & UAP & DP & PSP \\
\hline$F \quad 44$ & $A=03$ & A & $04 / 07 / 94$ & $7517: 03$ & & \\
\hline
\end{tabular}

Remarks

Tank condition was normal. The conductivity probe was properly deployed on the annulus floor.

\begin{tabular}{llll}
\hline$A-04$ & A & $04 / 07 / 94$ & $7517: 04$
\end{tabular}
Tank condition was nor$\mathrm{mal}$. The conductivity probe was properly deployed on the annulus floor.

A-04 A $12 / 07 / 94$
CCTV was used to obtain a closeup view of the item observed during an inspection made on $04-07-$ 94. The item on the ventilation duct was identified as an absorbent wipe. The inspection was documented on File Tape \#294.

\begin{tabular}{llll}
\hline P-01 & A & $06 / 01 / 94$ & $7640: 01-25$ \\
\hline P-02 & A & $06 / 07 / 94$ & $7683: 01-25$
\end{tabular}

Tank condition was normal.

Tank condition was normal. Stains observed on the ventilation duct and the annulus floor were caused by water which had leaked into the annulus. Tank condition was normal. Stains on the ventilation duct and annulus floor were caused by water wich had leaked into the annulus.

\begin{tabular}{llllll}
\hline P-04 & A & $04 / 07 / 94$ & $7517: 06$ & $\begin{array}{l}\text { Tank condition was nor- } \\
\text { mal. }\end{array}$ \\
\hline P-05 & A & $04 / 07 / 94$ & $7517: 07$ & $\begin{array}{l}\text { Tank condition was nor- } \\
\text { mal. }\end{array}$ \\
\hline P-06 & A & $04 / 07 / 94$ & $7517: 08$ & $\begin{array}{l}\text { Tank condition was nor- } \\
\text { mal. }\end{array}$ \\
\hline P-07 & A & $04 / 07 / 94$ & $7517: 09$ & $\begin{array}{l}\text { Tank condition was nor- } \\
\text { mal. }\end{array}$ \\
\hline P-08 & A & $06 / 01 / 94$ & & $7641: 01-25$ & $\begin{array}{l}\text { Tank condition was nor- } \\
\text { mal. }\end{array}$ \\
\hline
\end{tabular}




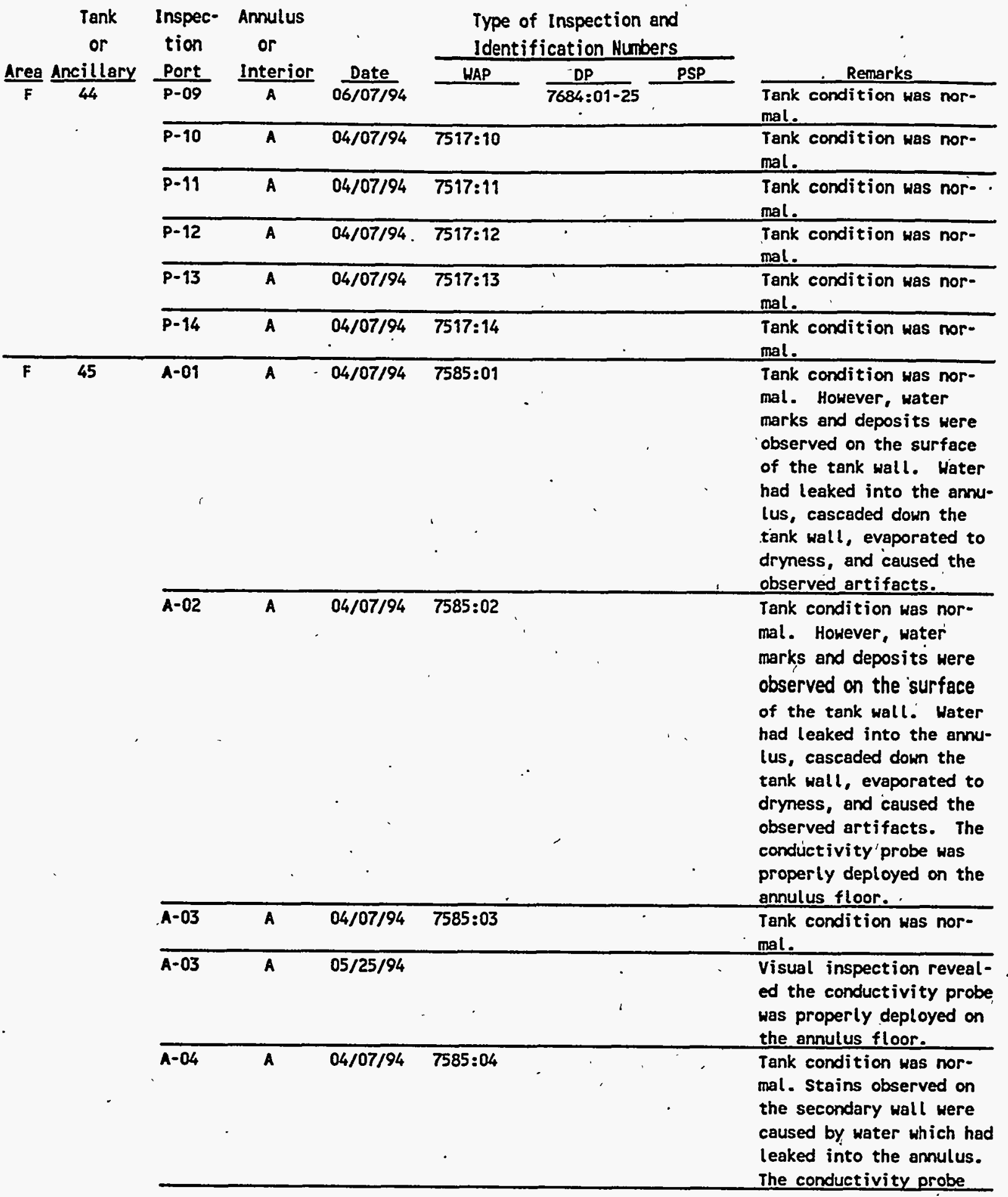




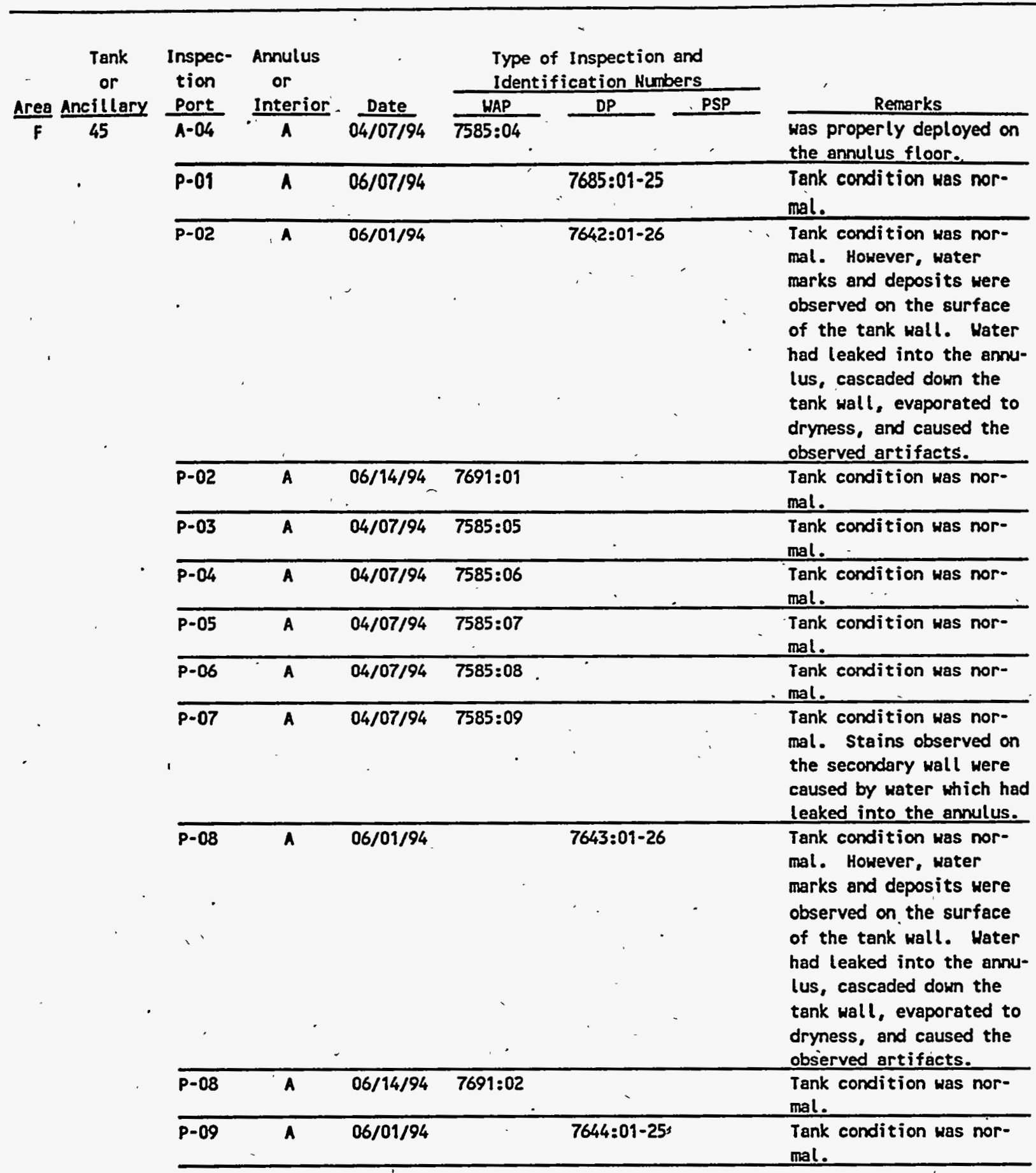




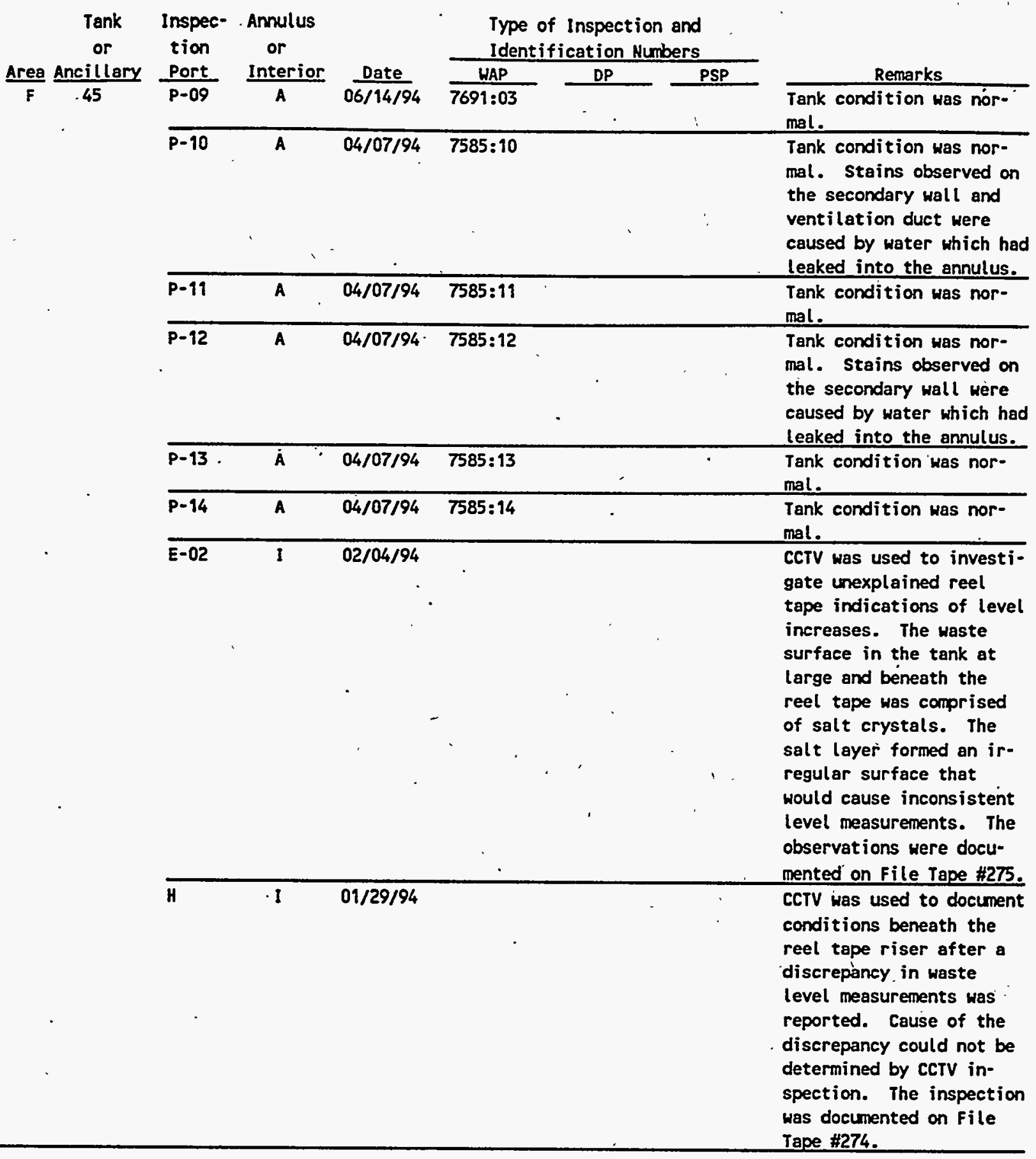




\begin{tabular}{|c|c|c|c|c|c|c|c|c|}
\hline & \multirow{2}{*}{$\begin{array}{c}\text { Tank } \\
\text { or } \\
\text { Ancillary }\end{array}$} & \multirow{2}{*}{$\begin{array}{l}\text { Inspec- } \\
\text { tion } \\
\text { Port } \\
\end{array}$} & \multirow{2}{*}{$\begin{array}{l}\text { Annulus } \\
\text { or } \\
\text { Interior }\end{array}$} & \multirow[b]{2}{*}{ Date } & \multicolumn{3}{|c|}{$\begin{array}{l}\text { Type of Inspection and } \\
\text { Identification Numbers }\end{array}$} & \multirow[b]{2}{*}{ Remarks } \\
\hline & & & & & WAP & $\mathrm{DP}$ & PSP & \\
\hline$F$ & 46 & $A-01$ & A & $05 / 27 / 94$ & $7690: 01$ & & 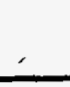 & $\begin{array}{l}\text { Tank condition was nor- } \\
\text { mal. }\end{array}$ \\
\hline & ' & $A-02$ & A & $05 / 27 / 94$ & $7690: 02$ & - & & $\begin{array}{l}\text { Tank condition was nor- } \\
\text { mal. The conductivity } \\
\text { probe was properly de- } \\
\text { ployed on the annulus } \\
\text { floor. }\end{array}$ \\
\hline & & $A-03$ & $A$ & $05 / 27 / 94$ & $7690: 03$ & & $\checkmark$ & $\begin{array}{l}\text { Tank condition was nor- } \\
\text { mal. The conductivity } \\
\text { probe was properly de- } \\
\text { ployed on the annulus } \\
\text { floor. }\end{array}$ \\
\hline & & $A-04$ & A & $05 / 27 / 94$ & $7690: 04$ & & & $\begin{array}{l}\text { Tank condition was nor- } \\
\text { mal. The conductivity } \\
\text { probe was properly de- } \\
\text { ployed on the annulus } \\
\text { floor. }\end{array}$ \\
\hline & $\cdot$ & P-01 & A & $06 / 07 / 94$ & & $7686: 01-25$ & & $\begin{array}{l}\text { Tank condition was nor- } \\
\text { mal. }\end{array}$ \\
\hline & & $p-02$ & A & $06 / 01 / 94$ & & $7645: 01-25$ & & $\begin{array}{l}\text { Tank condition has nor- } \\
\text { mal. }\end{array}$ \\
\hline & . & $P-03$ & A & 05/27/94 & $7690: 05$ & & " & $\begin{array}{l}\text { Tank condition was nor- } \\
\text { mal. }\end{array}$ \\
\hline & & $P-04$ & A & $05 / 27 / 94$ & $7623: 01$ & , & - & $\begin{array}{l}\text { Tank condition was nor- } \\
\text { mal. }\end{array}$ \\
\hline & & P.05 & A & $05 / 27 / 94$ & $7690: 06$ & & & $\begin{array}{l}\text { Tank condition was nor- } \\
\text { mal. Stains observed on } \\
\text { the annulus floor were } \\
\text { caused by water which had } \\
\text { leaked into the annulus. }\end{array}$ \\
\hline & & $P-06$ & $A$ & $\begin{array}{r}05 / 27 / 94 \\
\end{array}$ & $7623: 02$ & & . & $\begin{array}{l}\text { Tank condition was nor- } \\
\text { mal. }\end{array}$ \\
\hline & & $p-07$ & $A$ & $05 / 27 / 94$ & $7690: 07$ & & & $\begin{array}{l}\text { Tank condition was nor- } \\
\text { mal. }\end{array}$ \\
\hline & & P-08 & A & $06 / 01 / 94$ & & $7646: 01-26$ & & $\begin{array}{l}\text { Tank condition was nor- } \\
\text { mal. }\end{array}$ \\
\hline & & p-09 & $A$ & $06 / 07 / 94$ & & 7687:01-25 & & $\begin{array}{l}\text { Tank condition was nor- } \\
\text { mal. }\end{array}$ \\
\hline & . & $p-10$ & $A$ & $05 / 27 / 94$ & $7623: 03$ & & & $\begin{array}{l}\text { Tank condition was nor- } \\
\text { mal. }\end{array}$ \\
\hline & & $p-11$ & A & $05 / 27 / 94$ & $7690: 08$ & & & $\begin{array}{l}\text { Tank condition was nor- } \\
\text { mal. }\end{array}$ \\
\hline & & $p-12$ & A & $05 / 27 / 94$ & $\begin{array}{c}\text { 7623:04 } \\
.\end{array}$ & & - & $\begin{array}{l}\text { Tank condition was nor- } \\
\text { mal. A plastic bag was } \\
\text { observed on the annulus } \\
\text { floor. }\end{array}$ \\
\hline
\end{tabular}




\begin{tabular}{|c|c|c|c|c|c|c|c|c|}
\hline \multirow{5}{*}{$\frac{\text { Area }}{F}$} & \multirow{5}{*}{$\begin{array}{c}\text { Tank } \\
\text { or } \\
\text { Anci l lary } \\
46\end{array}$} & \multirow{3}{*}{$\begin{array}{l}\text { Inspec- } \\
\text { tion } \\
\text { Port } \\
\text { P-13 }\end{array}$} & \multirow{3}{*}{$\begin{array}{l}\text { Annulus } \\
\text { or } \\
\frac{\text { Interior }}{\text { A }}\end{array}$} & \multirow{3}{*}{$\frac{\text { Date }}{05 / 27 / 94}$} & \multicolumn{3}{|c|}{$\begin{array}{l}\text { Type of Inspection and } \\
\text { Identification Numbers }\end{array}$} & \multirow{3}{*}{$\begin{array}{l}\text { Remarks. } \\
\text { Tank condition was nor- } \\
\text { mal. Stains observed on } \\
\text { the annulus floor were } \\
\text { caused by water which had } \\
\text { leaked into the annulus. }\end{array}$} \\
\hline & & & & & HAP & $D P$ & PSP & \\
\hline & & & & & $7690: 09$ & & - & \\
\hline & & $p-14$ & A & $05 / 27 / 94$ & $7623: 05$ & & & $\begin{array}{l}\text { Tank condition was nor- } \\
\text { mal. }\end{array}$ \\
\hline & & $c-09$ & $I$ & $10 / 19 / 94$ & - & & . & $\begin{array}{l}\text { CCTV was used to guide } \\
\text { repositioning of the jet } \\
\text { and downconer in the c1 } \\
\text { riser and to perform leak } \\
\text { check. Ho leakage was } \\
\text { observed during the leak } \\
\text { check. The inspection } \\
\text { was documented on File } \\
\text { Tape } \$ 299 \text {. }\end{array}$ \\
\hline \multirow[t]{3}{*}{$F$} & 47 & $A-01$ & A & $05 / 27 / 94$ & $7625=01$ & & & $\begin{array}{l}\text { Tank condition was nor- } \\
\text { mal. }\end{array}$ \\
\hline & - & $A-02$ & A & $05 / 27 / 94$ & $7625: 02$ & & & $\begin{array}{l}\text { Tank condition was nor- } \\
\text { mal. The conductivity } \\
\text { probe was properly de- } \\
\text { ployed on the annulus } \\
\text { floor. }\end{array}$ \\
\hline & & $A-03$ & A & $05 / 27 / 94$ & $7625: 03$ & & & $\begin{array}{l}\text { Tank condition was nor- } \\
\text { mal. The conductivity } \\
\text { probe was properly de- } \\
\text { ployed on the annulus } \\
\text { floor. }\end{array}$ \\
\hline \multirow[t]{3}{*}{ - } & & A-04 & $A$ & $05 / 27 / 94$ & $7625: 04$ & & & $\begin{array}{l}\text { Tank condition was nor- } \\
\text { mal. Stains observed on } \\
\text { the annulus floor were } \\
\text { caused by water which had } \\
\text { leaked into the annulus. } \\
\text { The conductivity probe } \\
\text { was properly deployed on } \\
\text { the annulus floor. }\end{array}$ \\
\hline & & $P-01$ & A & $05 / 27 / 94$ & & $7647: 1$ & & $\begin{array}{l}\text { Tank condition was nor- } \\
\text { mal. A rubber glove was } \\
\text { observed on the annulus } \\
\text { floor. }\end{array}$ \\
\hline & $\cdot$ & $p-02$ & A & $05 / 27 / 94$ & & $7648:$ & 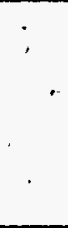 & $\begin{array}{l}\text { Tank condition was nor- } \\
\text { mal. Approximately } 3 \\
\text { feet of small diameter } \\
\text { plastic tubing was ob- } \\
\text { served on the annulus } \\
\text { floor. }\end{array}$ \\
\hline
\end{tabular}




\begin{tabular}{|c|c|c|c|c|c|c|c|c|}
\hline \multirow{2}{*}{ Area } & \multirow{2}{*}{$\begin{array}{c}\text { Tank } \\
\text { or } \\
\text { Ancillary }\end{array}$} & \multirow{2}{*}{$\begin{array}{c}\text { Inspec- } \\
\text { tion } \\
\text { Port }\end{array}$} & \multirow{2}{*}{$\begin{array}{c}\text { Annulus } \\
\text { or } \\
\text { Interior }\end{array}$} & \multirow[b]{2}{*}{ Date } & \multicolumn{3}{|c|}{$\begin{array}{l}\text { Type of Inspection and } \\
\text { Identification Numbers }\end{array}$} & \multirow[b]{2}{*}{ Remarks } \\
\hline & & & & & WAP & $D P$ & PSP & \\
\hline \multirow[t]{12}{*}{$F$} & 47 & $P-03$ & A & $05 / 27 / 94$ & $7625: 05$ & & & $\begin{array}{l}\text { Tank condition was nor- } \\
\text { mal. }\end{array}$ \\
\hline & & P. 04 & $A$ & $05 / 27 / 94$ & $7625: 06$ & & & $\begin{array}{l}\text { Tank condition was nor- } \\
\text { mal. }\end{array}$ \\
\hline & , & $p-05$ & A & 05/27/94 & $7625: 07$ & & & $\begin{array}{l}\text { Tank condition was nor- } \\
\text { mal. Stains observed on } \\
\text { the secondary wall were } \\
\text { caused by water which had } \\
\text { leaked into the annulus. }\end{array}$ \\
\hline & & P-06 & A & $\begin{array}{l}05 / 27 / 94 \\
\end{array}$ & $7625: 08$ & & & $\begin{array}{l}\text { Tank condition was nor- } \\
\text { mal. }\end{array}$ \\
\hline & . & $p-07$ & A & $05 / 27 / 94$ & $7625: 09$ & & & $\begin{array}{l}\text { Tank condition was nor- } \\
\mathrm{mal} \text {. }\end{array}$ \\
\hline & & P-08 & A & $06 / 01 / 94$ & - & $7649: 01-26$ & & $\begin{array}{l}\text { Tank condition was nor- } \\
\text { mal. }\end{array}$ \\
\hline & & P-09 & A & $\begin{array}{r}06 / 01 / 94 \\
\end{array}$ & $\therefore$ & $7650: 01-26$ & & $\begin{array}{l}\text { Tank condition was nor- } \\
\text { mal. }\end{array}$ \\
\hline & & $p-10$ & A & $05 / 27 / 94$ & $7625: 10$ & & & $\begin{array}{l}\text { Tank condition was nor- } \\
\text { mal. }\end{array}$ \\
\hline & & $P-11$ & A & $05 / 27 / 94$ & $7625: 11$ & . & & $\begin{array}{l}\text { Tank condition was nor- } \\
\text { mal. }\end{array}$ \\
\hline & & $p-12$ & A & $05 / 27 / 94$ & $7625: 12$ & & & $\begin{array}{l}\text { Tank condition was 'nor- } \\
\mathrm{mal} \text {. }\end{array}$ \\
\hline & . & $P-13$ & A & $05 / 27 / 94$ & $7625: 13$ & & & $\begin{array}{l}\text { Tank condition was nor- } \\
\text { mal. }\end{array}$ \\
\hline & & $p-14$ & A & $05 / 27 / 94$ & $7625: 14$ & & & $\begin{array}{l}\text { Tank condition was nor-, } \\
\text { mal. }\end{array}$ \\
\hline \multirow[t]{4}{*}{ H } & 48 & $A-01$ & A & $05 / 25 / 94$ & $7621: 01$ & & & $\begin{array}{l}\text { Tank condition was nor- } \\
\text { mal. }\end{array}$ \\
\hline & & $A-02$ & $A$ & $05 / 25 / 94$ & $7621: 02$ & & - & $\begin{array}{l}\text { Tank condition was nor- } \\
\text { mal. The conductivity } \\
\text { probe was properly de- } \\
\text { ployed on the annulus } \\
\text { floor. }\end{array}$ \\
\hline & & $A-03$ & A & $05 / 25 / 94$ & $7621: 03$ & & * & $\begin{array}{l}\text { Tank condition was nor- } \\
\text { mal. The conductivity } \\
\text { probe was properly de- } \\
\text { ployed on the annulus } \\
\text { floor. }\end{array}$ \\
\hline & & $A-04$ & A & $05 / 25 / 94$ & $7621: 04$ & & & $\begin{array}{l}\text { Tank condition was nor- } \\
\text { mal. The conductivity } \\
\text { probe was properly de- } \\
\text { ployed on the annulus } \\
\text { floor. }\end{array}$ \\
\hline
\end{tabular}




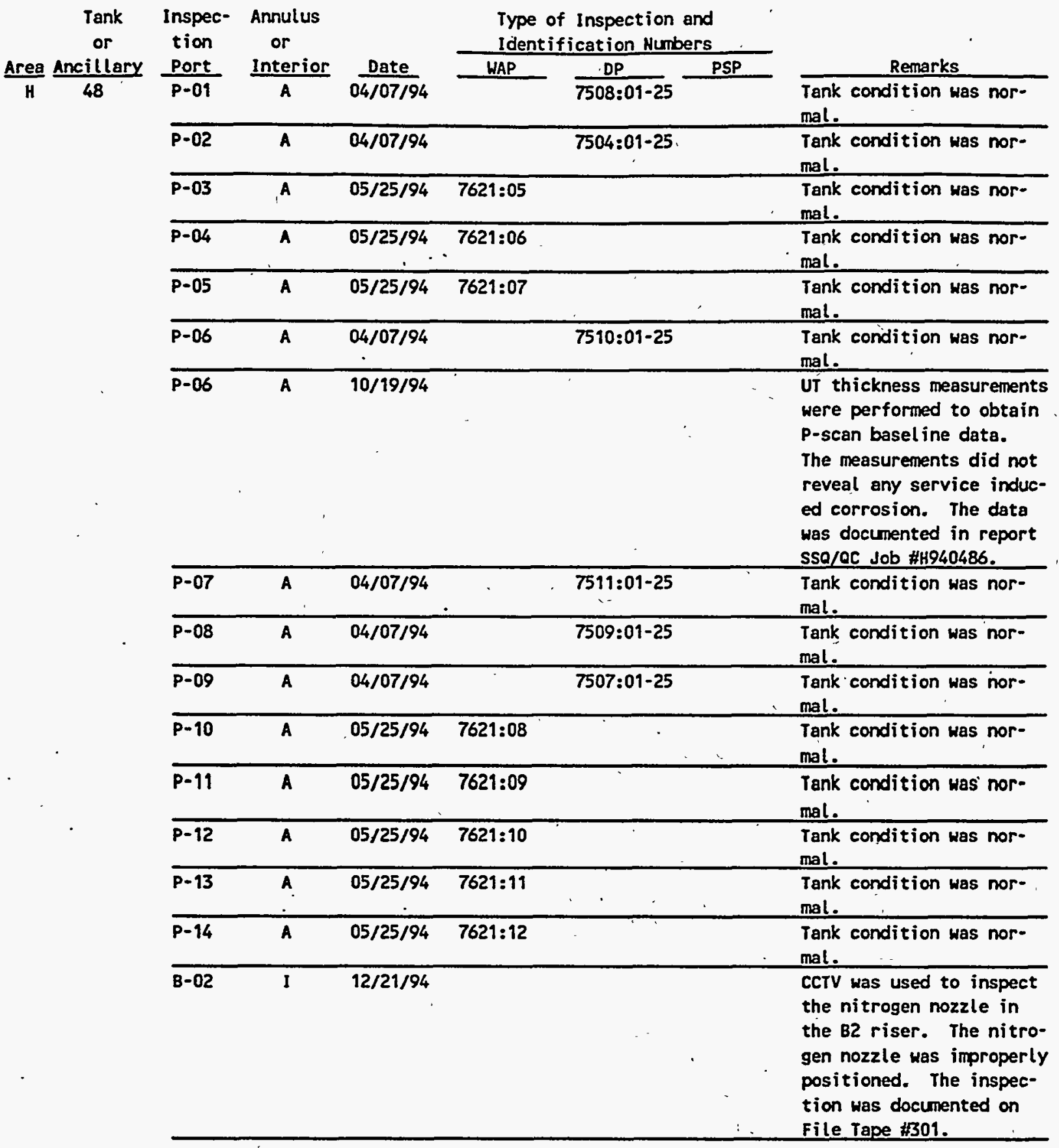




$\begin{gathered}\text { Tank Inspec- Annulus } \\ \text { or } \\ \text { tion or } \\ \text { Area Ancillary }\end{gathered} \frac{\begin{array}{c}\text { Port } \\ \text { P }\end{array} \frac{\text { Interior }}{\mathrm{C}-03} \frac{\text { Date }}{12 / 21 / 94}}{\text { I }} \begin{gathered}\text { Type of Inspection and } \\ \text { Identification Numbers }\end{gathered}$

$\frac{\text { Remarks }}{\text { CCTV was used to inspect }}$ the nitrogen nozzle in the $\mathrm{C} 3$ riser. The nitrogen nozzle was properly positioned. The inspection was documented on File Tape \$301.

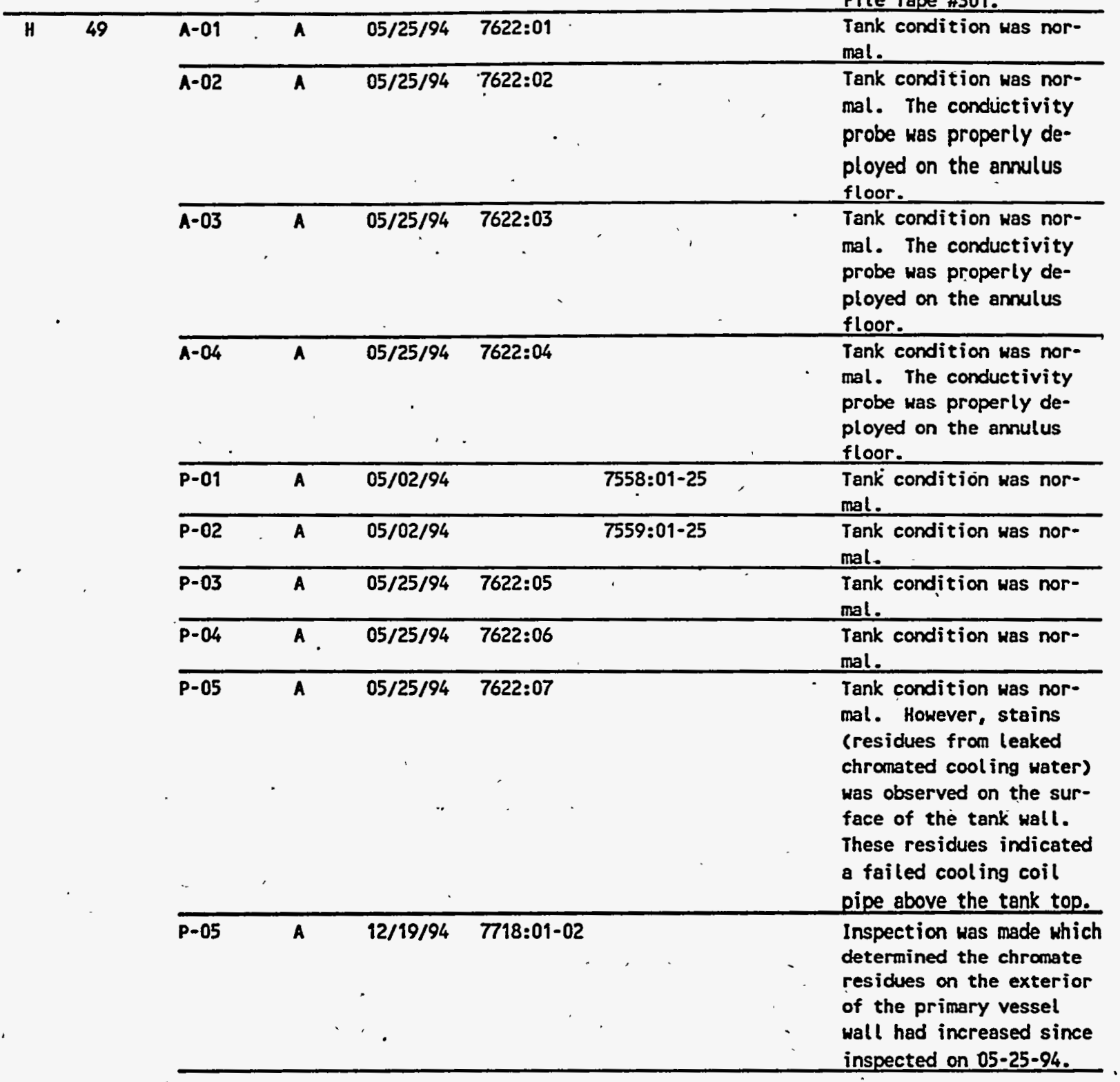




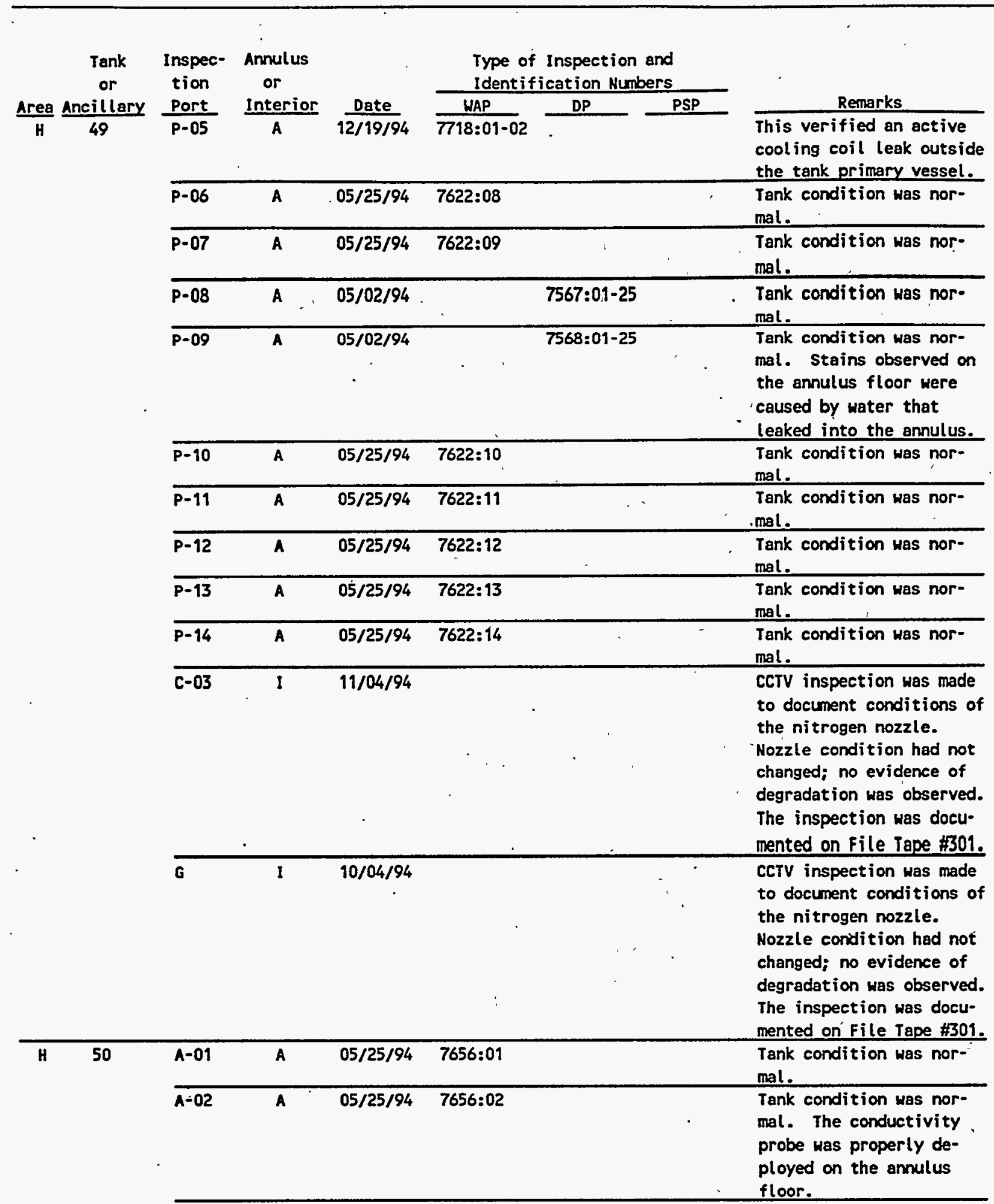




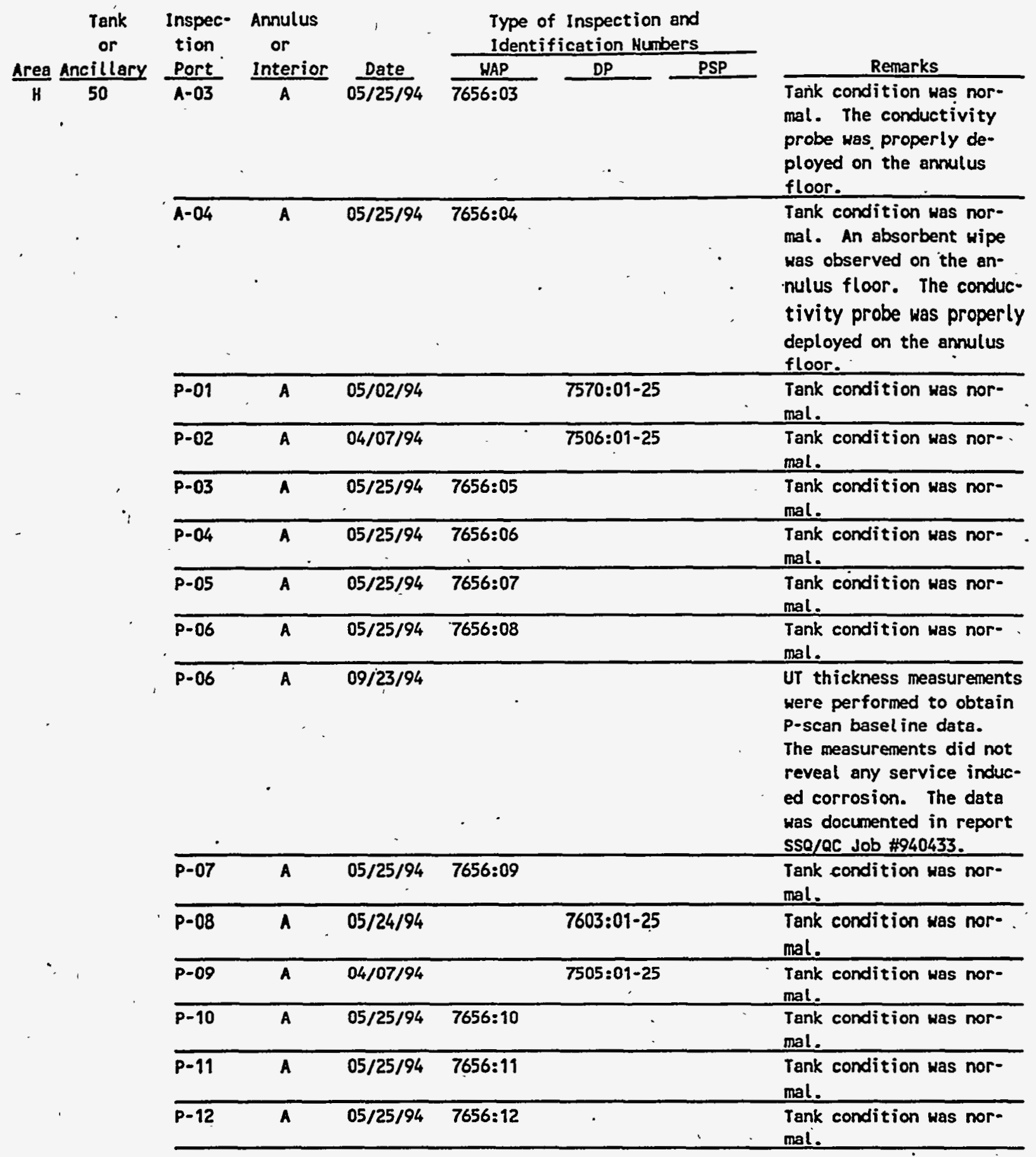




\begin{tabular}{|c|c|c|c|c|c|c|c|c|c|}
\hline \multirow{4}{*}{$\frac{\text { Area }}{H}$} & \multirow{2}{*}{$\begin{array}{c}\begin{array}{c}\text { Tenk } \\
\text { or } \\
\text { Ancillary }\end{array} \\
\frac{5 n}{}\end{array}$} & \multirow{3}{*}{$\begin{array}{l}\text { Inspec- } \\
\text { tion } \\
\text { Port } \\
\text { p-13 }\end{array}$} & \multirow{3}{*}{$\begin{array}{l}\text { Annulus } \\
\text { or } \\
\frac{\text { Interior }}{A}\end{array}$} & \multirow{3}{*}{$\frac{\text { Date }}{05 / 25 / 94}$} & \multicolumn{3}{|c|}{$\begin{array}{l}\text { Type of Inspection and } \\
\text { Identification Numbers }\end{array}$} & \multirow{2}{*}{\multicolumn{2}{|c|}{ Remarks }} \\
\hline & & & & & HAP & $D P$ & PSP & & \\
\hline & 50 & & & & $7656: 13$ & & : & & $\begin{array}{l}\text { Tank condition was nor- } \\
\text { mal. }\end{array}$ \\
\hline & . & $p-14$ & A & $05 / 25 / 94$ & $7656: 14$ & - & & & $\begin{array}{l}\text { Tank condition was nor- } \\
\text { mal. }\end{array}$ \\
\hline \multirow[t]{15}{*}{ H } & 51 & $A-01$ & A & $03 / 15 / 94$ & $7500: 01$ & & & & $\begin{array}{l}\text { Tank condition was nor- } \\
\text { mal. }\end{array}$ \\
\hline & 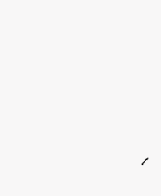 & $A-02$ & A & $03 / 15 / 94$ & $7500: 02$ &. & $:$ & 1 & $\begin{array}{l}\text { Tank condition was nor- } \\
\text { mal. The conductivity } \\
\text { probe was properly de- } \\
\text { ployed on the annulus } \\
\text { floor. }\end{array}$ \\
\hline & - & $A-03$ & A & $03 / 22 / 94$ & $7500: 03$ & · & & & $\begin{array}{l}\text { Tank condition was nor- } \\
\text { mal. The conductivity } \\
\text { probe was properly de- } \\
\text { ployed on the annulus } \\
\text { floor. }\end{array}$ \\
\hline & $\because$ & $A-04$ & $A$ & $03 / 22 / 94$ & $\begin{array}{l}7500: 04 \\
.\end{array}$ & $i$ & & & $\begin{array}{l}\text { Tank condition was nor- } \\
\text { mal. The conductivity } \\
\text { probe was properly de- } \\
\text { ployed on the annulus } \\
\text { floor. }\end{array}$ \\
\hline & & P-01 & A & $04 / 08 / 94$ & & $7522: 01-25$ & & & $\begin{array}{l}\text { Tank condition wạs nor- } \\
\text { mal. }\end{array}$ \\
\hline & & $p-02$ & A & $04 / 08 / 94$ & & $7523: 01-25$ & & & $\begin{array}{l}\text { Tank condition was nor- } \\
\text { mal. }\end{array}$ \\
\hline & $\cdot$ & P-03 & A & $03 / 15 / 94$ & $7500: 05$ & $\ddot{*}$ & & & $\begin{array}{l}\text { Tank condition. was nor- } \\
\text { mal. }\end{array}$ \\
\hline & $\cdot$ & P-04 & A & $03 / 15 / 94$ & $7500: 06$ & & .• & & $\begin{array}{l}\text { "Tank condition was nor- } \\
\text { mal. }\end{array}$ \\
\hline & . & P.05 & A & $03 / 15 / 94$ & $7500: 07$ & & & & $\begin{array}{l}\text { Tank condition was nor- } \\
\text { mal. }\end{array}$ \\
\hline & & P-06 & A & $03 / 22 / 94$ & $7500: 08$ & & & & $\begin{array}{l}\text { Tank condition was nor- } \\
\text { mal. }\end{array}$ \\
\hline & & $P=07$ & A & $12 / 19 / 94$ & $7717: 01$ & & & & $\begin{array}{l}\text { Tank condition was nor- } \\
\text { mal. }\end{array}$ \\
\hline & & P-08 & A & $03 / 22 / 94$ & & $7502: 01-25$ & & & $\begin{array}{l}\text { Tank condition was nor- } \\
\text { mal. }\end{array}$ \\
\hline & & P-09 & A & $04 / 08 / 94$ & & $7526: 01-25$ & . & & $\begin{array}{l}\text { Tank condition was nor- } \\
\text { mal. }\end{array}$ \\
\hline & & $P-10$ & A & $03 / 22 / 94$ & $7500: 09$ & . & & & $\begin{array}{l}\text { Tank condition was nor- } \\
\text { mal. }\end{array}$ \\
\hline & & $P-11$ & A & $03 / 22 / 94$ & $7500: 10$ & & & & $\begin{array}{l}\text { Tank condition was nor- } \\
\text { mal. }\end{array}$ \\
\hline
\end{tabular}




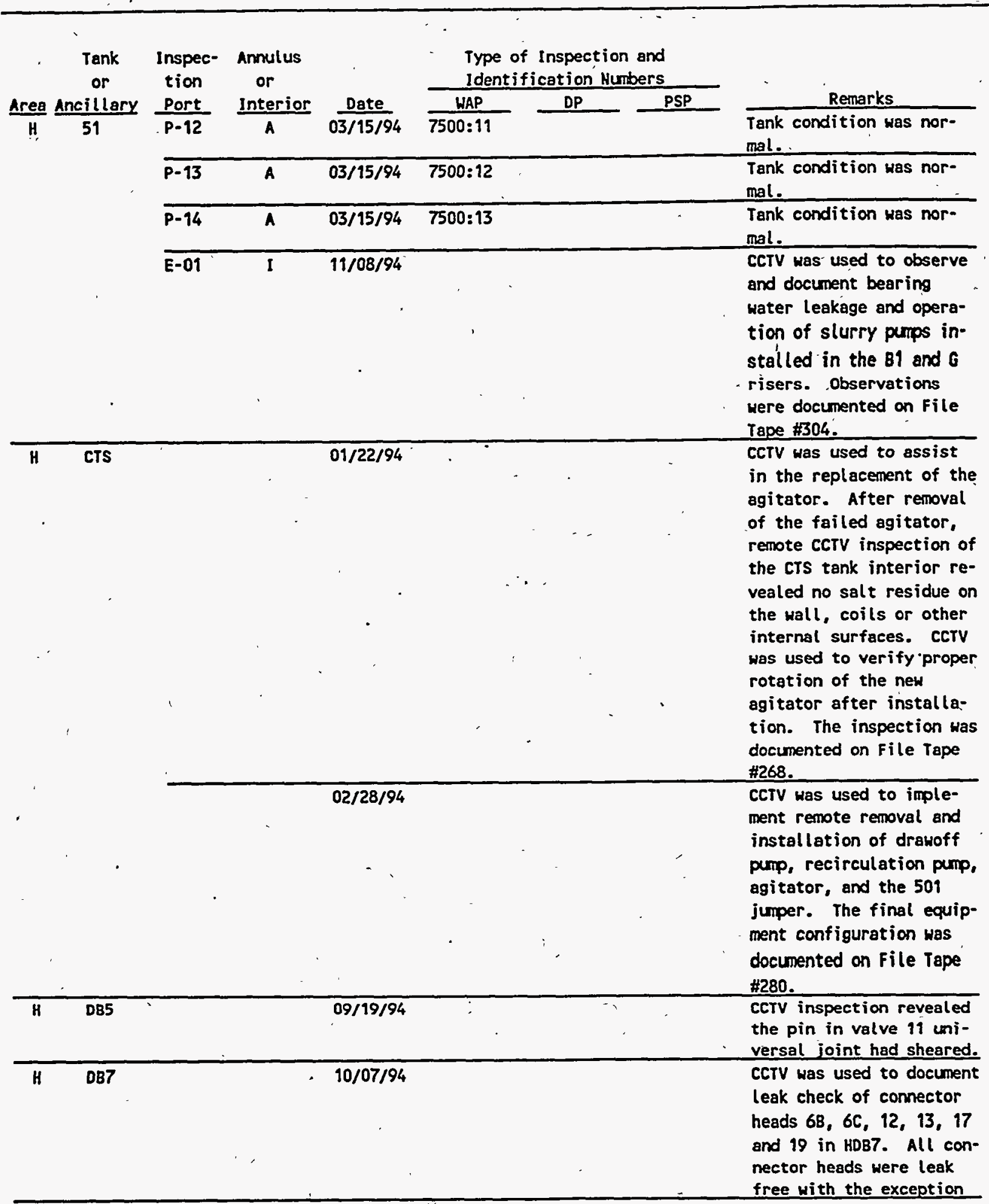




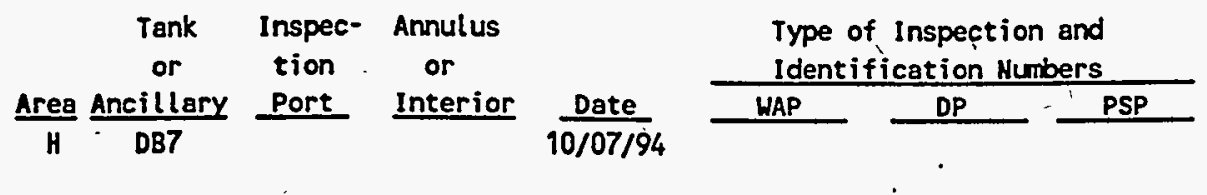

of $6 \mathrm{C}$ which was tightened intil it properly sealed. The inspection was documented on file Tape \#298. CCTV was used to determine the operability of valve $\$ 7$ at HDB7. The inspection revealed that the valve pin had sheared at the universal joint. The valve position was verified by CCTV.

$\begin{array}{lll}\text { H } & \text { OB8 } & 11 / 30 / 94\end{array}$
cCTV was ised to inspect pipe for debris left during construction. Ho debris was observed in the line from nozzle \#8 in DB8 to nozzle $\$ 3$ in PT10. CCTV was used to inspect pipes for debris left during construction. No debris was observed in lines from floor nozzles $4,7,11,12$ or 14 . Slag was observed in lines from floor nozzles 6,8 , 9 and 16. An unidentified object was observed in the line from floor nozzle \#10. pipes for debris left during construction. Ho debris was observed in lines from floor nozzles $3,5,13$ or 15 . Slag was observed in lines from floor nozzles 1 and 2 . Also, a welding rod was observed. in the line from floor nozzle \#2.

\begin{tabular}{llll}
\hline H EVAP1 SE & $02 / 26 / 94$
\end{tabular}
cCTV was used to document conditions in the $1 \mathrm{H}$ evaporator cell. Ho unusual conditions were observed." The inspection 


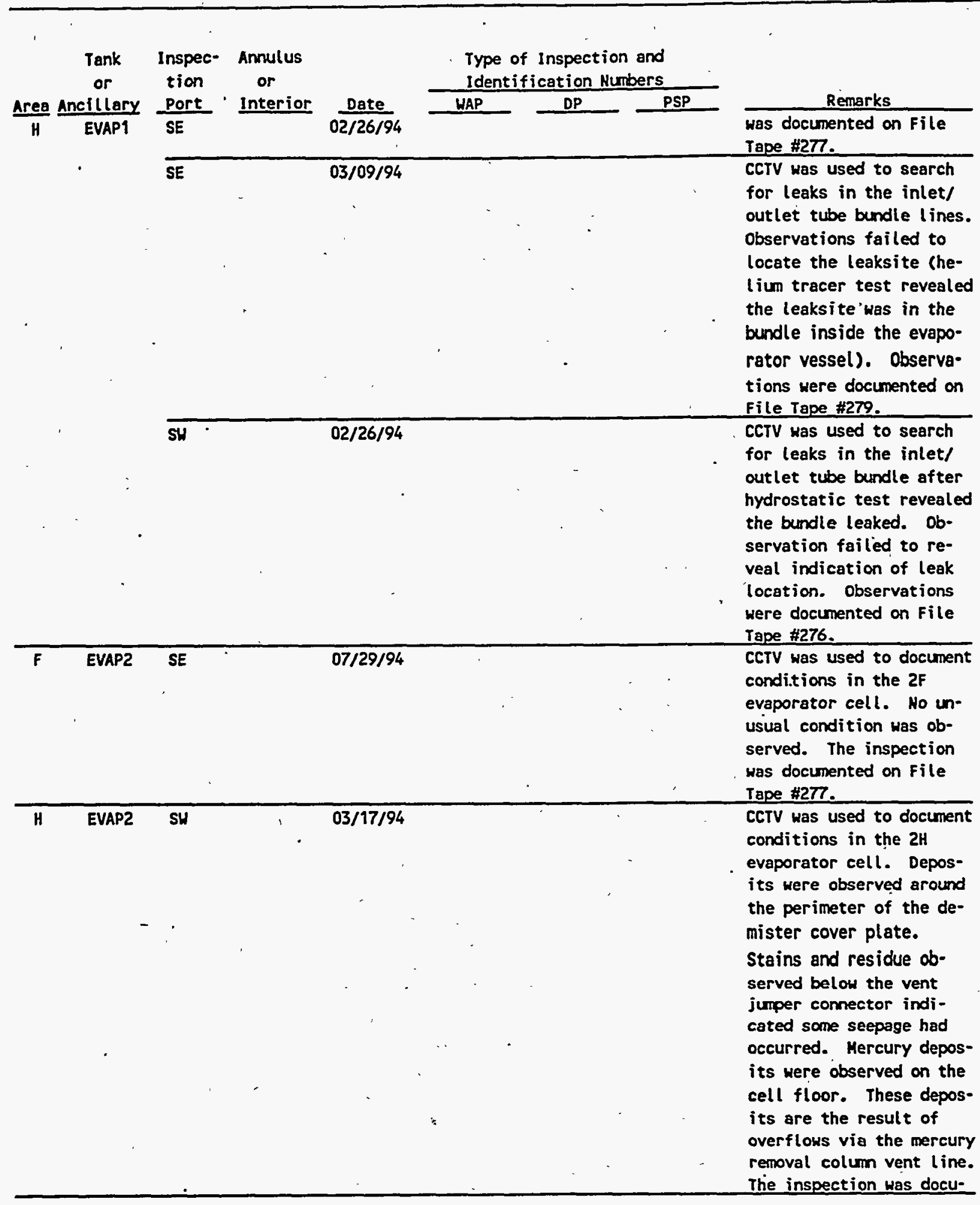




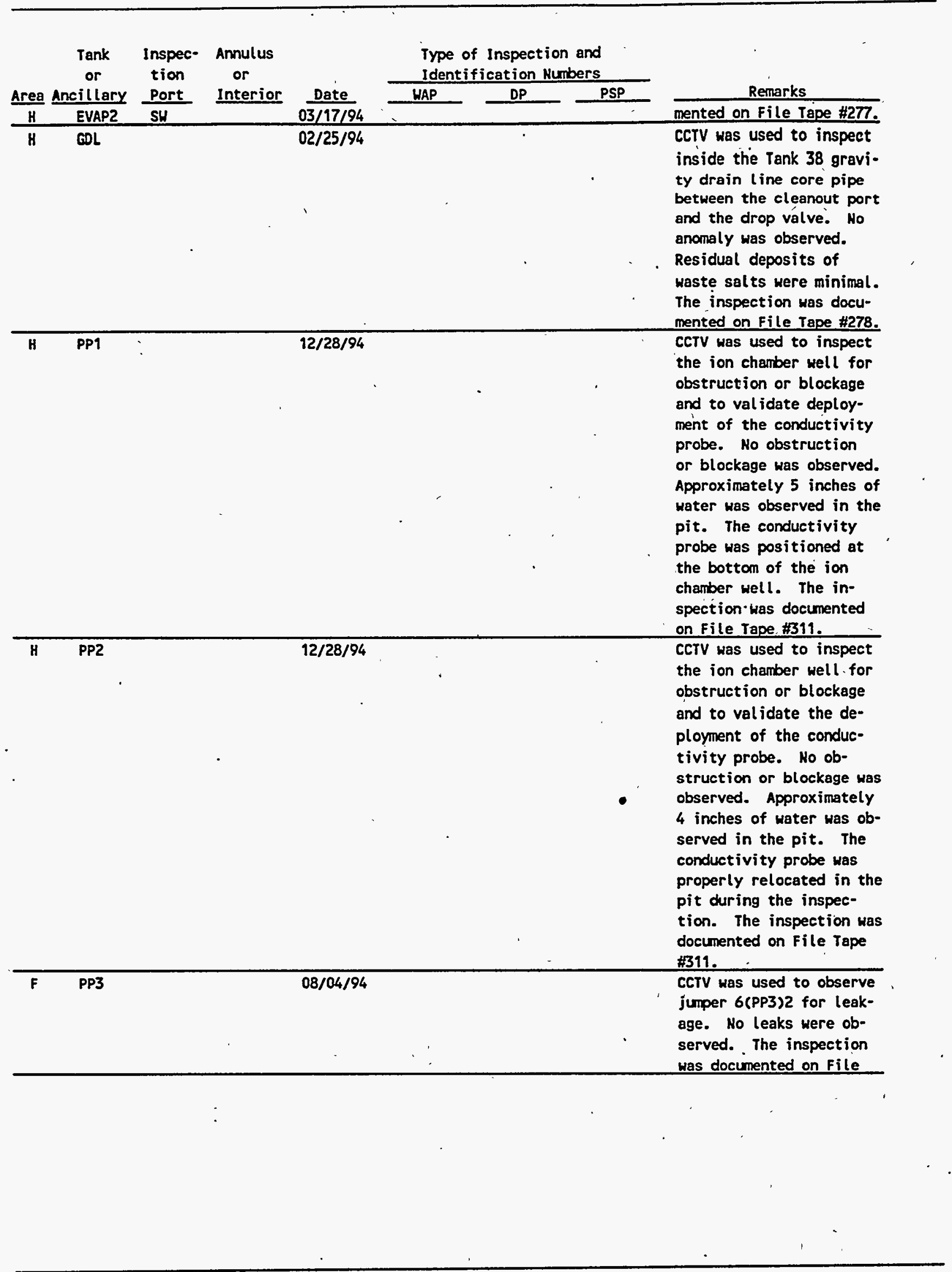




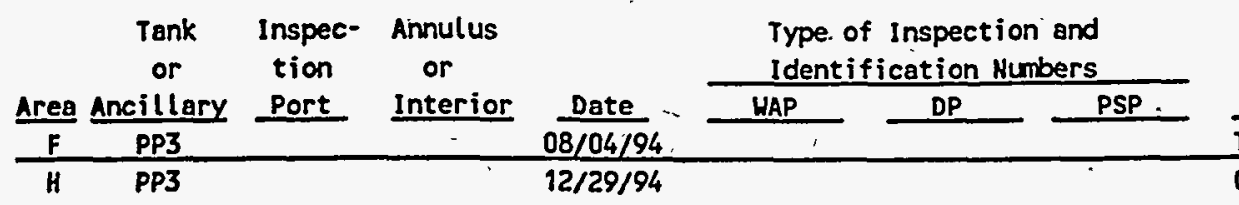

Tape \#289.

CCTV was used to inspect the ion chamber well for obstruction or blockage and to validate deployment of the conductivity. probe. Ho obstruction or blockage was observed. The conductivity probe was positioned at the botton of the ion chamber well: The inspection was documented on file Tape \#311.

\begin{tabular}{lll}
\hline$H$ & PP4 & $12 / 29 / 94$
\end{tabular}

CCTV was used to inspect the ion chamber well for obstruction or blockage and to validate deployment of the conductivity probe. Ho obstruction or blockage was observed. Water was observed in the pit. The conductivity probe was properly deployed approximately one inch above the water. The inspection was 'documented on file Tape $\$ 311$.

\begin{tabular}{lll}
\hline H & RHLHE & $12 / 02 / 94$
\end{tabular}
CCTV was used in an effort to inspect the sump of the Replacement High Level Waste Evaporator (RHLUE). The sump could not be inspected because it was full of water.

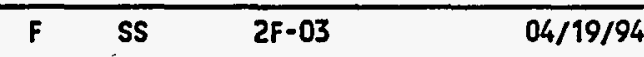
CCTV was used to document conditions and establish. basel ine for future inspections. Sediment 2-4" deep was observed in the inlet and outlet concrete pipes. Standing water was present in these lines approximately 8-10" deep. The opening of five inlet drains were in- 


\begin{tabular}{|c|c|c|c|c|c|c|c|}
\hline \multirow{3}{*}{\multicolumn{2}{|c|}{$\begin{array}{c}\begin{array}{c}\text { Tank } \\
\text { or } \\
\text { Area Ancillary }\end{array} \\
\end{array}$}} & \multirow{2}{*}{$\begin{array}{l}\text { Inspec- } \\
\text { tion } \\
\text { Port } \\
\end{array}$} & \multirow{3}{*}{$\begin{array}{l}\text { Annulus } \\
\text { or } \\
\text { Interior }\end{array}$} & \multirow{3}{*}{$\frac{\text { Date }}{04 / 19 / 94}$} & \multicolumn{3}{|c|}{$\begin{array}{l}\text { Type of Inspection and } \\
\text { Identification Numbers }\end{array}$} \\
\hline & & & & & WAP & DP & PSP \\
\hline & SS & $2 F-03$ & & & & & \\
\hline
\end{tabular}

spected in this storm drain. The South inlet has a 6" line inserted and the remainder of the line was filled with concrete. A few random voids were observed in the mortar joints of the brick liner. No evidence of structural failure or infiltration through the liner was observed. The inspection was documented on File Tape \#285.

\begin{tabular}{l}
\hline 3F-04 \\
$05 / 02 / 94$
\end{tabular}

CCTV was used to document conditions and establish basel ine for future in$\because$ spections. Sediment was observed approximately 2-4" deep in the inlet and outlet concrete pipe. Water cascading down from a small inlet drain has caused erosion of the south 18" concrete pipe. No evidence of structural failure or significant infiltration through the liner was observed. The inspection was documented on. File Tape \#285.

3F-06 04/19/94

CCTV was used to document conditions and establish basel ine for future inspections. Sediment 2-4"1 deep was observed in the inlet and outlet concrete pipe. A few random voids were present in the mortar joints of the brick liner. Ho evidence of structural failure or significent infiltration through the liner was observed. The inspection was documented on File Tape \#285: 


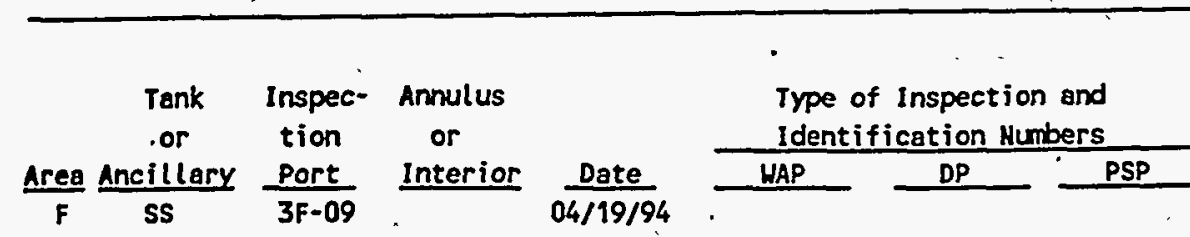

CCTV was used to document conditions and establish baseline for future inspections. Sediment 2-4u deep was observed in the inlet and outlet concrete pipe. Ho evidence of structural failure or significant infiltration through the liner was observed. The inspection was documented on file Tape \#285.

4F-03 03/30/94

CCTV was used to document conditions and establish baseline for future inspections. The 18 inch diameter sewer pipes were about half full of water indicating sediment was about 8 to 9 inches deep. A few random voids were present in the mortar joints of the brick liner beneath the stean blowdown outlet. Voids were present in the joint between the brick and concrete liners and between the indiviual concrete liners. Ho evidence of structural failure or significant infiltration through the liner was observed. The inspection was documented on File Tape \#285.

\begin{tabular}{lll}
\hline 4F-04 03/30/94 & $\begin{array}{l}\text { Tape } \# 285 . \\
\text { cctv was used to document } \\
\text { conditions and establish } \\
\text { baseline for future in- } \\
\text { spections. The } 18 \text { inch } \\
\text { diameter sewer pipes con- } \\
\text { tained sediment about } 8\end{array}$ \\
& $\begin{array}{l}\text { to } 9 \text { inches deep. A few } \\
\text { random voids were present } \\
\text { in the mortar joints of } \\
\text { the brick liner. No evi- }\end{array}$ \\
\hline
\end{tabular}




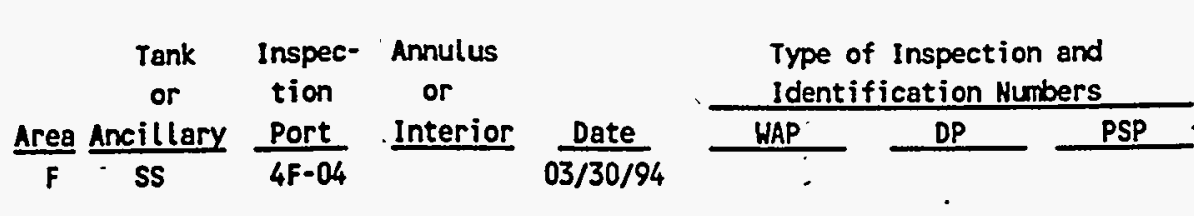

4F-05 03/30/94

failure or significant infiltration through the liner was observed. The inspection was documented on file Tape \#285.

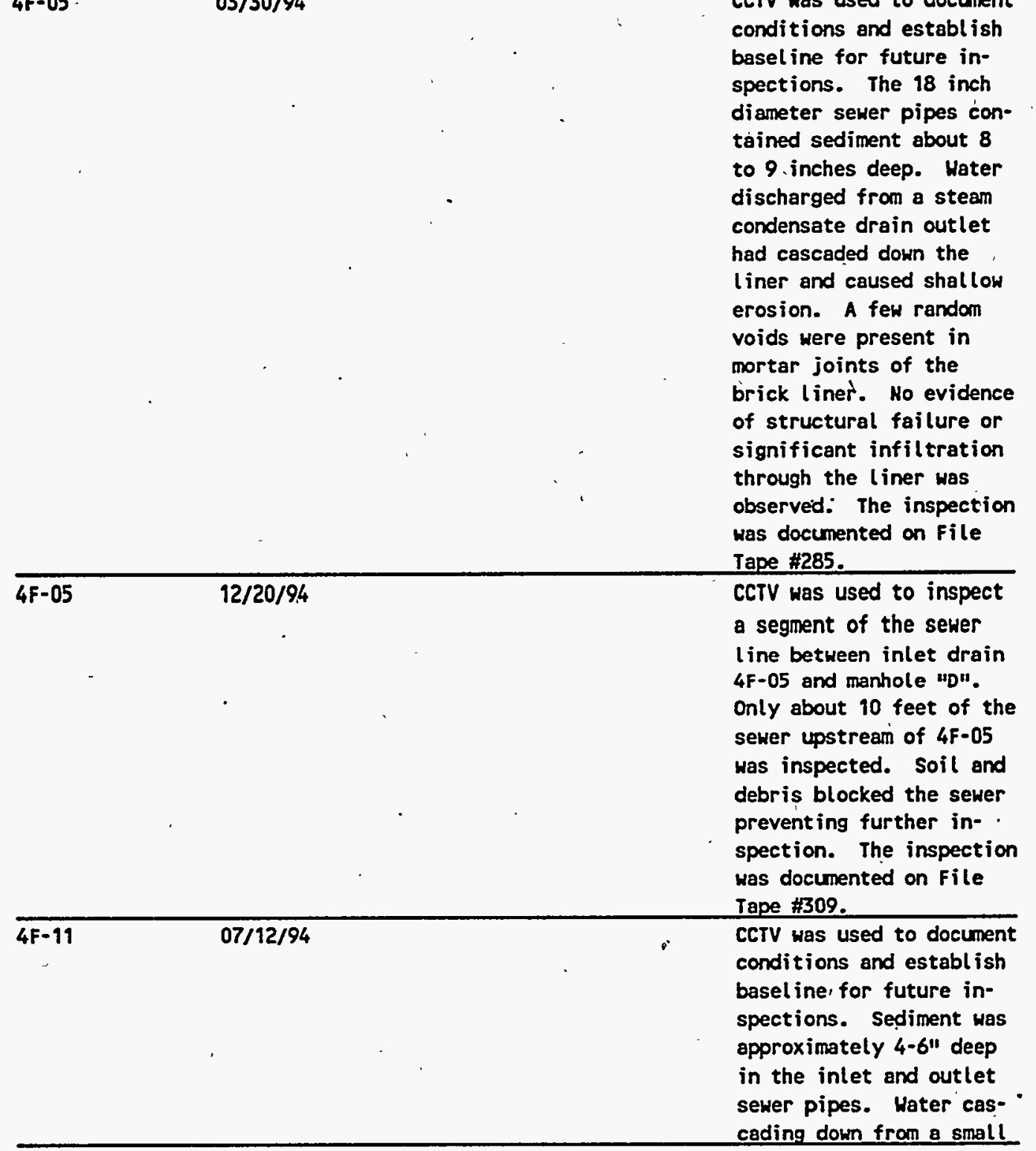




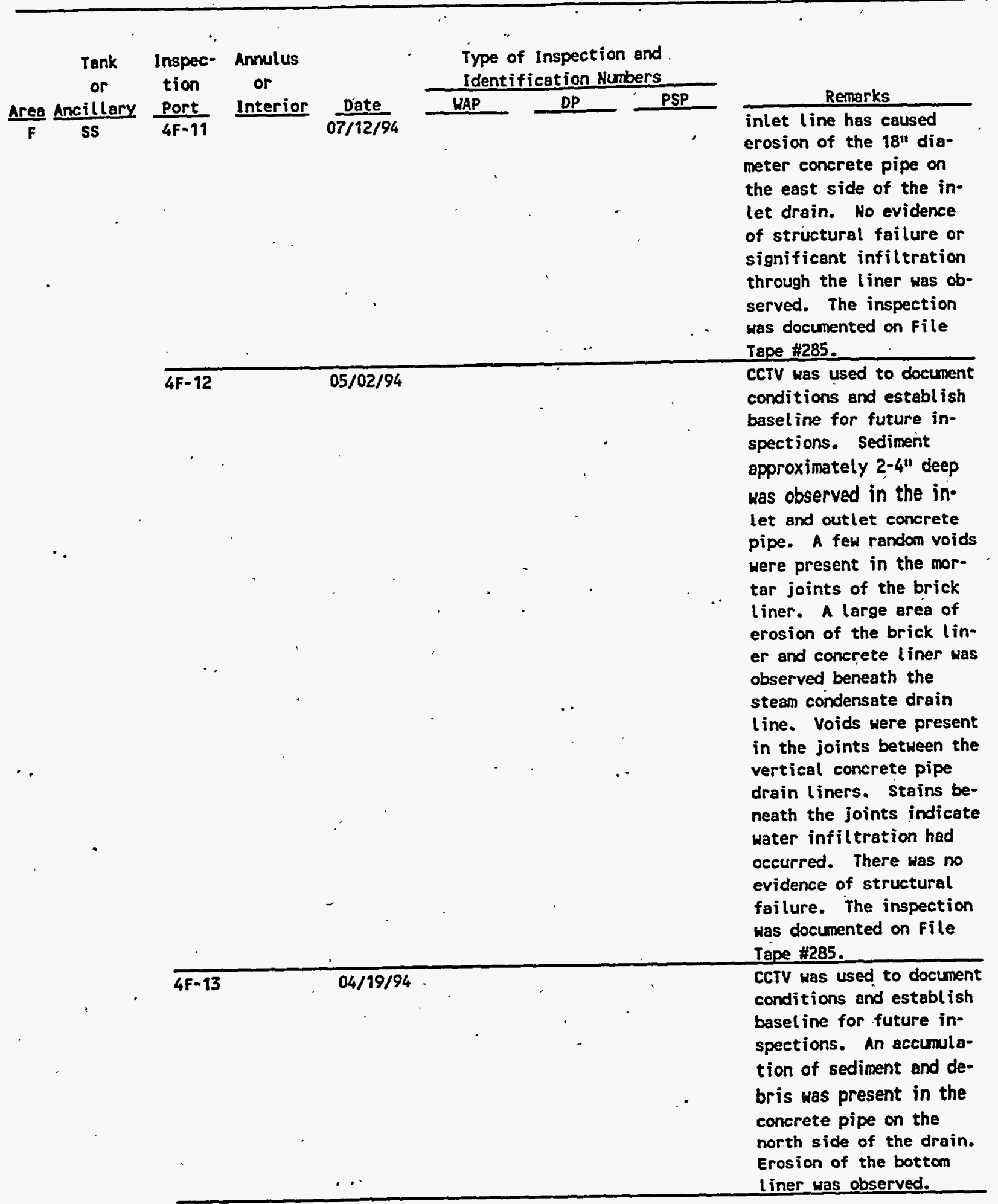




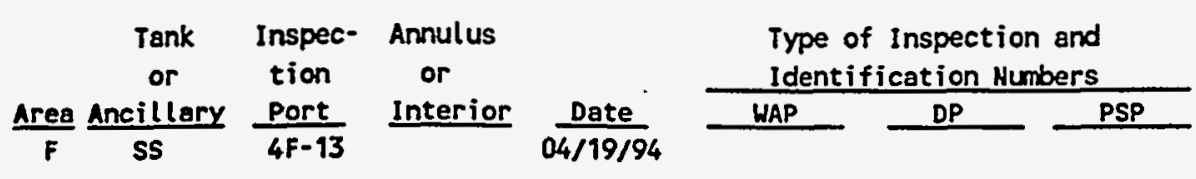

$\frac{\text { Remarks }}{\text { There was also evidence }}$ of undermining of the botton liner. There was considerable erosion of the 18" diameter concrete pipe caused by the stean condensate line directly above. This erosion was within the drain and does not affect the performance of the concrete pipe. A few randon voids were present in the mortar joints of the brick liner. There was no evidence of structural failure or significant infiltration through the liner. The inspection was documented on file Tape \#285.

CCTV was used to document conditions and establish basel ine for future inspections. Sediment 2-4" deep was observed in the inlet and outlet concrete drain pipe. A feu random voids were present in the brick mortar joints of the brick liner. A large area of the brick liner below the stean condensate drain showed signs of erosion. There was no evidence of structural failure or significant infiltration through the liner. The inspection was documented on file Tape \#285.

CCTV was used to document conditions and establish a baseline for future in: spections. The south sewer line appeared to be misaligned creating 


\begin{tabular}{|c|c|c|c|c|c|c|}
\hline \multirow{2}{*}{$\begin{array}{c}\begin{array}{c}\text { Tank } \\
\text { or } \\
\text { Area Ancillary }\end{array} \\
\end{array}$} & \multirow{2}{*}{$\begin{array}{l}\text { Inspec- } \\
\text { tion } \\
\text { Port } \\
\end{array}$} & \multirow{2}{*}{$\begin{array}{l}\text { Annulus } \\
\text { or } \\
\text { Interior }\end{array}$} & \multirow[b]{2}{*}{ Date } & \multicolumn{3}{|c|}{$\begin{array}{l}\text { Type of Inspection and } \\
\text { Identification Humbers }\end{array}$} \\
\hline & & & & UAP & $D P$ & PSP \\
\hline
\end{tabular}

Identification Numbers

F

$4 F-19$

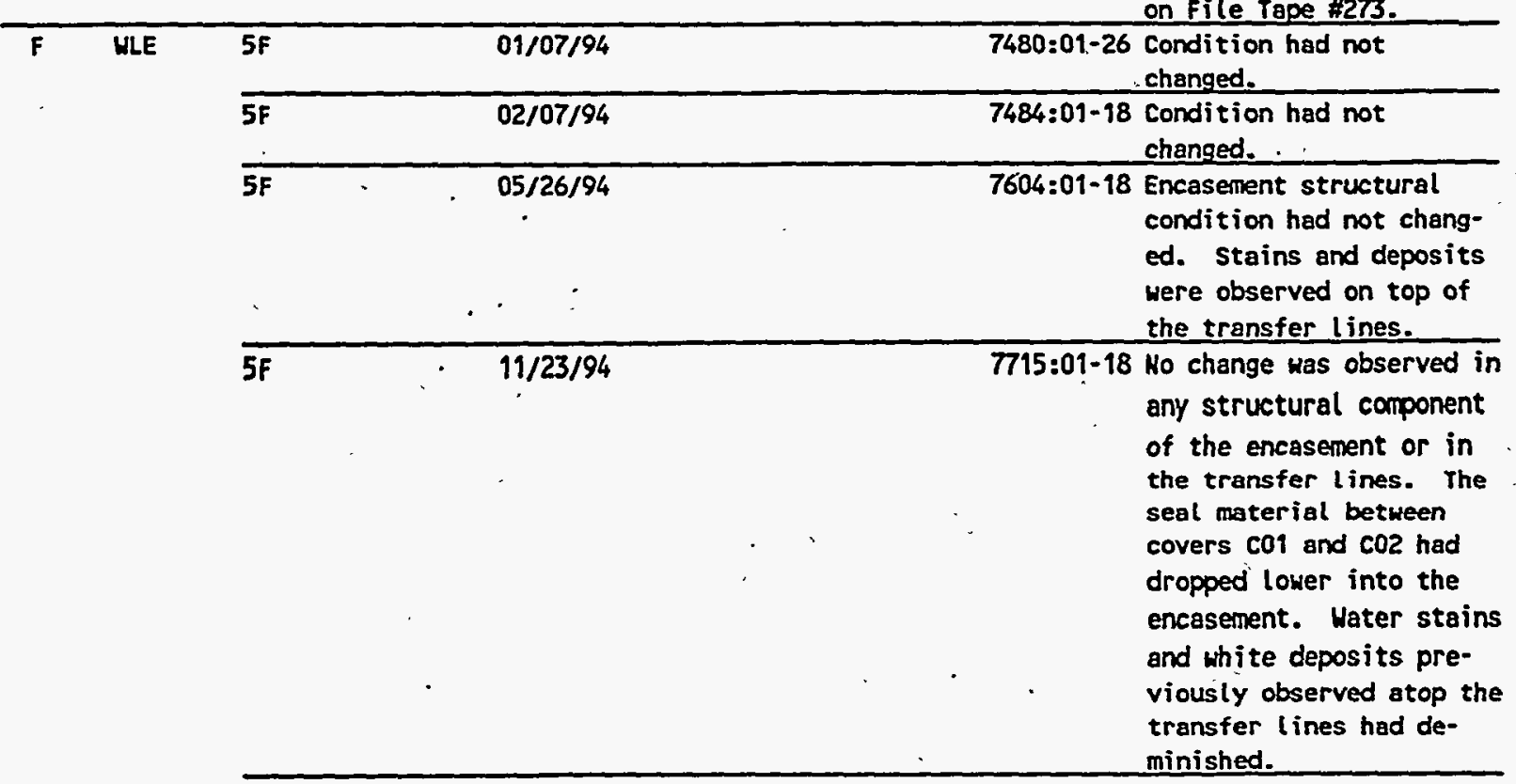

CCTV was used to document conditions and establish basel ine for future inspections. A few random voids were present in the mortar joints of the brick liner beneath the stean bloudown outlet. The north sewer line appeared to be misaligned creating standing water at the pipe joint. No evidence of structural failure or significant infiltration through the liner was observed. The inspection was documented on File Tape \$273.

standing water at the pipe joint. No evidence of structural failure or significant infiltration through the liner was observed. The inspection was documented on File Tape \#273. 


\begin{tabular}{|c|c|c|c|c|c|c|c|c|}
\hline \multirow{2}{*}{\multicolumn{2}{|c|}{$\begin{array}{c}\begin{array}{c}\text { Tank } \\
\text { or } \\
\text { Area Ancillary }\end{array} \\
\text { HLE }\end{array}$}} & \multirow{3}{*}{$\begin{array}{l}\text { Inspec- } \\
\text { tion } \\
\text { Port } \\
6 \mathrm{~F}\end{array}$} & \multirow{3}{*}{$\begin{array}{l}\text { Annulus } \\
\text { or } \\
\text { Interior } \\
\end{array}$} & \multirow{3}{*}{$\frac{\text { Date }}{01 / 10 / 94}$} & \multicolumn{3}{|c|}{$\begin{array}{l}\text { Type of Inspection and } \\
\text { Identification Numbers. }\end{array}$} & \multirow[b]{2}{*}{ Remarks } \\
\hline & & & & & HAP & $\mathrm{DP}$ & PSP & \\
\hline$F$ & & & & & & & $7481: 01-36$ & $\begin{array}{l}\text { Condition had not } \\
\text { changed. }\end{array}$ \\
\hline
\end{tabular}

The numbers listed under WAP, DP, and PSP identify photographs in the HLWE files. WAP = wide angle photography; $D P=$ direct photography; $P S P=$ periscopic photography; CTS = concentrate transfer system; $D B=$ diversion box; EVAP = evaporator; $G D L$ = gravity drain line; PP = pump pit; RHLHE = replacement high level waste evaporator; SS = storm sewer; WLE $=$ waste line encasement. 